\title{
Religião, educação e futuro Práticas escolares desafiadas pelo pluralismo, laicidade e intolerância
}

\section{A mediação escolar como instrumento auxiliar de construção da tolerância/respeito à diversidade religiosa}

\author{
School mediation as anauxiliary instrument for the construction of tolerance/respect for \\ religious diversity.
}

\author{
Marselha Evangelista de Souza ${ }^{1}$ \\ mar.evangelistasouza@gmail.com \\ Geovane Lopes de Oliveira ${ }^{2}$ \\ geovanelopesoliveira@gmail.com
}

\begin{abstract}
Resumo: A Base Nacional Comum Curricular de 2017 estabelece o ensino religioso como disciplina de oferta obrigatória e matrícula facultativa pautada na interculturalidade e na ética da alteridade, visando a compreensão das múltiplas crenças e o respeito a elas. Contudo, a atual exacerbação da intolerância religiosa, reverberada nas relações escolares, e a resistência à disciplina, fruto da falsa ideia de doutrinação, podem mitigar o resultado pretendido e catalisar disputas. Nesse contexto, a mediação, como método de solução de conflitos, garantindo espaço à escuta e à empatia e atribuindo às partes protagonismo no processo de busca pela solução negociada através do reconhecimento do outro, pode ser aliada no desenvolvimento do ensino religioso, desde que compreendidas e adequadamente aplicadas suas ferramentas.
\end{abstract}

Palavras-chave: ensino religioso, intolerância religiosa, identidade, mediação de conflitos.

Abstract: The National Curricular Common Core of 2017 establishes religious teaching as a compulsory subject and optional matriculation based on interculturality and the ethics of otherness, aiming at understanding multiple beliefs and respect for them. However, the current exacerbation of religious intolerance ever berated in school relations and resistance to discipline as a result of the false idea of indoctrination can mitigate the intended result and catalyze disputes. In this context, mediation, as a method of conflict resolution, guaranteeing space for listening and empathy and attributing to the parties protagonism in these a reach process for the negotiated solution through there cognition of the other, can beallied in the development of religious education, provided that understood and properly applied their tools.

\footnotetext{
${ }^{1}$ Mestre em Ciência da Religião pela UFJF. Bacharel em direito pela UFJF. Professora do curso de direito da Faculdade de Ciências Gerencias José Alves Fortes, da Fundação Educacional de Além Paraíba.

${ }^{2}$ Mestre em Direito internacional e integração econômica pela UERJ. Bacharel em direito pela UFJF. Professor do curso de direito da Faculdade de Ciências Jurídicas e Gerenciais José Alves Fortes, da Fundação Educacional de Além Paraíba
} 
Key words: religious teaching, religious intolerance, identity, conflict mediation.

\section{Introdução}

Em dezembro de 2017, através da Resolução $n^{\circ} 2$ do Conselho Nacional de Educação (CNE), foi instituída e implementada a Base Nacional Curricular (BNCC) que deverá ser observada ao longo do desenvolvimento da Educação Básica. A BNCC tem como base legal a Lei 9.394/1996, a Lei de Diretrizes e Bases da Educação (LDB), que prevê o estabelecimento de uma base nacional comum e traça os princípios que guiam o ensino. $\mathrm{O}$ ensino religioso está previsto na $\mathrm{LDB}^{3}$ como disciplina integrante da formação básica, de matrícula facultativa, que deve respeitar a diversidade sem proselitismo. $\mathrm{Na}$ BNCC não foi diferente o tratamento dado ao ensino religioso, que é estabelecido como componente curricular das escolas públicas no ensino fundamental, sendo de oferta obrigatória e matrícula facultativa.

Embora o ensino religioso tenha surgido e sido implantado historicamente no Brasil com viés estritamente confessional e como parte de um processo catequizante, o que se buscou, nos últimos anos foi a desvinculação com uma confessionalidade tanto em relação ao conteúdo quanto em relação à formação do profissional que ministram a disciplina (Santos et al., 2009). Como bem demarca Cunha (2014), os processos de discussão em torno da segunda LDB, polarizando, de um lado os defensores de um ensino completamente laico, e, de outro, os defensores da ampliação da confessionalidade, produziram um documento híbrido.

Pode-se dizer, com isso, que o confronto acabou por viabilizar a concretização de um projeto emancipatório que, reconhecendo a importância da religião como expressão cultural formadora das identidades, viabilizou, também, o desenvolvimento de uma disciplina apta a apresentar a pluralidade de perspectivas culturais sobre o divino, que parece ser absolutamente compatível com o processo específico de formação do campo religioso brasileiro, na linha do postulado por Sanchis (2018). Assim, na BNCC, o ensino religioso torna-se reflexo da nova Ordem Constitucional, que prevê a educação como forma de pleno desenvolvimento da pessoa, com vistas ao exercício da cidadania, demarcando o caráter laico do Estado:

\footnotetext{
${ }^{3}$ Art. 33 - O ensino religioso, de matrícula facultativa, é parte integrante da formação básica do cidadão e constitui disciplina dos horários normais das escolas públicas de ensino fundamental, assegurado o respeito à diversidade cultural religiosa do Brasil, vedadas quaisquer formas de proselitismo. (Redação dada pela Lei $\mathrm{n}^{\circ}$ 9.475, de 22.7.1997)
} 
A partir da década de 1980, as transformações socioculturais que provocaram mudanças paradigmáticas no campo educacional também impactaram no Ensino Religioso. Em função dos promulgados ideais de democracia, inclusão social e educação integral, vários setores da sociedade civil passaram a reivindicar a abordagem do conhecimento religioso e o reconhecimento da diversidade religiosa no âmbito dos currículos escolares. (CNE, 2017, p. 433).

Mesmo sendo tratada de forma não confessional, a disciplina Ensino Religioso traz muitas questões que passam pela visão confessional/proselitista que ainda permeia a sociedade. Esse contexto complexo e sujeito a muitas disputas e apropriações indevidas da disciplina será equacionada através da qualificação/formação do profissional que irá ministrar a disciplina, o que, na visão de Soares (2015) e de Rodrigues (2013), deve ser buscado na especialidade em Ciência da Religião, como melhor caminho.

A formação oferecida pela Ciência da Religião tem condições de superar o proselitismo historicamente atribuído ao Ensino Religioso, pela superação do comprometimento com instituições religiosas, pelo compromisso de rigor teóricometodológico e pelo avanço dos reducionismos forjados no âmbito de outras disciplinas cujo objeto central é outro que não a religião. (Rodrigues, 2013, p. 240).

Ainda assim, o pleno desenvolvimento dos objetivos pretendidos com a disciplina do ensino religioso, no que tange à construção da capacidade crítica de compreensão das múltiplas dimensões do transcendente, terá de enfrentar a questão da adesão dos educandos, haja vista o caráter facultativo da disciplina. E, nesse contexto, surgirão os maiores desafios do desenvolvimento do conteúdo, visto que as discussões sobre a religião e a religiosidade na formação dos indivíduos, apresentando as diversas possibilidades históricoculturais de manifestação e consolidação social do fenômeno, implicará na contraposição de valores pessoais consolidados e poderá levar a conflitos a respeito de diferenças irreconciliáveis e irrenunciáveis. É nesse âmbito que a mediação, como método de solução de conflitos, pode garantir espaço à escuta e à empatia, através de ferramentas que, atribuindo às partes protagonismo no processo de busca pela solução negociada através do reconhecimento do outro, garantam a convivência pacífica das diferenças e a possiblidade de crescimento mútuo. São esses aspectos que serão explorados neste artigo.

\section{1 - Intolerância religiosa, identidade e o ensino religioso}

Embora seja predominantemente cristã, a população brasileira é permeada por uma pluralidade de crenças religiosas de matrizes diversas, conforme constatou-se no Censo 
Demográfico do IBGE realizado em 2010. A pesquisa indicou que mais de $86 \%$ da população brasileira se declarava cristã (entre católicos e evangélicos de várias denominações), mas identificou também a existência de mais de 40 grupos religiosos registrados no país (IBGE, 2010). Mesmo no espectro cristão, a diversidade é uma marca da composição do Brasil. Da mesma forma que essa pluralidade é um traço capaz de viabilizar o respeito à diferença, é também um catalizador de violência e intolerância.

O Ministério dos Direito Humanas (MDH), através do serviço "Disque 100", recebe denúncias sobre intolerância religiosa. De janeiro a junho de 2017, o "Disque 100" registrou 169 denúncias de intolerância religiosa, sendo que 39,05\% dessas ocorrências teve como vítimas praticantes de candomblé, umbanda e demais religiões de matriz africana (MDH, 2017). Conforme dados do ministério, de janeiro de 2015 ao primeiro semestre de 2017, o Brasil registrou uma denúncia a cada 15 horas (Resk,Tomazela e Cotrim, 2017).No Rio de Janeiro, de janeiro a março de 2018 os casos de intolerância religiosa aumentaram 56\%, segundo dados da Secretaria de Estado de Direitos Humanos e Políticas para Mulheres e Idosos (Molina, 2018). O Relatório de Intolerância Religiosa no Brasil, de 2016 (Santos et al. - orgs., 2016), com dados correspondentes ao período entre 2012 e 2015, indica uma escalada das agressões motivadas por questões religiosas, com ponto alto em 2013 e consolidação entre 2013 e 2015 em patamares substancialmente maiores do que aqueles apurados em 2012.

Diante desses cenários de intolerância, principalmente com as religiões de matriz afro, como trazer o educando para o ensino religioso, como fazê-lo optar e permanecer em uma formação que visa a inclusão e o respeito à diferença? Como estimular o educando a conhecer e respeitar aquilo que vem sendo tratado de forma violenta?

Como aponta Cavalcanti (2016, p. 70), com base nos dados do Relatório Final da Intolerância Religiosa no Brasil e nos relatórios do Disque 100, as "unidades de ensino além de apresentarem um silêncio no quesito religiosidades, são também ambientes onde se manifestam o desrespeito". Isso, somado ao fato, também destacado pela autora, de que são as crianças os principais alvos da intolerância religiosa, induz à conclusão de que há uma necessidade premente em se construir instrumentos de desenvolvimento das habilidades dos profissionais para lidar com a questão. Valendo-se de estudos situados no Rio de Janeiro, de autoria de Ana Paula Miranda, Fábio Mota, Cavalcanti ressalta, ainda, que:

[...] a disciplina de ensino religioso acabou por se evidenciar como um elemento não relevante. A resistência por parte do alunado não é derivada de uma concepção laica de educação, mas embebida de discursos religiosos para se contrapor a conteúdos consagrados de outras disciplinas. De igual forma, os discursos construídos revelam práticas de não tolerância a conteúdos referentes a outras religiões, em especial, àquelas de matriz afro-brasileira. (Cavalcanti, 2016, p. 74) 
É evidente que a intolerância religiosa não nasce na escola, tanto quanto também não nasce na escola a identificação religiosa. A intolerância religiosa é um conflito que está fora dos portões das escolas, está na sociedade brasileira e é transportado para o ambiente escolar. Na verdade, é preciso reconhecer que as escolhas religiosas individuais, como elemento de identificação e construção do sujeito em si, são constructos sócio-políticos, num contexto multicultural, que coloca em choque as múltiplas possibilidades de autoreferência. E, a partir disso, em vez de negar relevância a tais diferenças, relegando-as aos espaços privados, deve-se garantir-lhes presença nos espaços públicos, legitimando sua expressão e manifestação.

Nesse contexto, o ensino religioso, embora muitas vezes combatido como inadequado e incabível no âmbito de um estado laico ${ }^{4}$, como é o caso do Brasil (sobretudo nos termos definidos pela Constituição da República, de 1988), acaba porconverter-se justamente no principal mecanismo de aperfeiçoamento da convivência pacífica da pluralidade de percepções do sagrado que formam as identidades sujeitos que compõem a sociedade brasileira.

Burity (1997), já no final do século passado insistia na questão de que a formação da identidade religiosa é, de si, um aspecto da construção política do sujeito, ou seja, um constructo que forma e é formado pelo campo político.E, embora o citado autor esteja discutindo a inserção do campo religioso no campo político, suas conclusões podem ser aproveitadas também na análise da formação da identidade dos sujeitos. Dito de outro modo, o pluralismo na sociedade contemporânea não é só uma constatação intransponível. Ele é, de si, constitutivo dessa sociedade, e reflete um processo sempre inacabado de consolidações e disrupções no todo social.

Assim, toda tentativa de "domesticar" essa diversidade, reconduzindo os indivíduos a uma perspectiva universalista que negue relevância ao pluralismo na esfera pública acaba por alimentar antagonismos sociais num sentido negativo. Essa crença contemporânea na possibilidade e/ou necessidade de superação das diferenças, da desvinculação dos indivíduos de suas identidades coletivas (comum, por exemplo, no discurso que nega relevância ao ensino religioso baseando na leitura enviesada do conceito de laicidade do Estado e pautada na negação dos elementos religiosos como formadores dos indivíduos), instaura uma visão antipolítica que nega o reconhecimento da dimensão

\footnotetext{
${ }^{4}$ Ver, por todos, Cunha (2016).
} 
antagônica constitutiva da sociedade, professando um mundo para além da de diferença, em que a pluralidade tomada como um fato e, por isso, relegada à esfera privada e neutralizada na esfera pública. Mouffe (1996), discorrendo sobre a formação das identidades (no geral e não especificamente quanto à esfera do sagrado) é precisa:

Com efeito, sugiro que todas as formas de pluralismo que dependem de uma lógica do social que implique a idéia de "ser como presença" e veja a "objetividade" como pertencente às "coisas em si mesmas", necessariamente levam à redução do pluralismo e a sua negação em última instância. Este é, de fato, o caso das principais formas de pluralismo liberal, que geralmente começa pelo destaque do que chamam "o fato do pluralismo" e então procedem à busca por procedimentos que assimilem as diferenças cujo objetivo é na verdade tornar tais diferenças irrelevantes e relegar o pluralismo à esfera do privado.

Visto de uma perspectiva teórica anti-essencilista, ao contrário, o pluralismo não é meramente um fato, algo que devemos engolir a contragosto ou tentar reduzir, mas um princípio axiológico [...] considerado como algo que devemos celebrar e intensificar. É por isso que o tipo de pluralismo que estou advogando dá um status positivo às diferenças e que refuta o objetivo da unanimidade e homogeneidade que é sempre revelado como fíctício e baseado em atos de exclusão. (Mouffe, 1996, p. 246)

O reconhecimento do conflito como inseparável do desenvolvimento da vida em comum é a condição de possibilidade de superação da intolerância religiosa. O ensino religioso, assim, precisa levar para os educandos uma nova visão sobre a religião, para combater esse problema social. Para isso, busca-se o desenvolvimento de competências específicas tais como aquelas explicitadas na BNCC:

Reconhecer e cuidar de si, do outro, da coletividade e da natureza, enquanto expressão de valor da vida; Conviver com a diversidade de crenças, pensamentos, convicções, modos de ser e viver; debater, problematizar e posicionar-se frente aos discursos e práticas de intolerância, discriminação e violência de cunho religioso, de modo a assegurar os direitos humanos no constante exercício da cidadania e da cultura de paz. (CNE, 2017, p.435).

A inclusão do ensino religioso na formação de crianças e adolescentes, nos termos definidos pela BNCC, tem como objetivo suscitar a habilidades de autoconhecimento e de alteridade, não só no que se refere aos fenômenos religiosos, mas também às filosofias seculares de vida, proporcionando, assim, uma ampla formação dos educandos. Ao se deparar com outras formas de percepção do transcendente, o educando poderá ver a si e aos demais, poderá reconhecer aquilo que faz sentido para sua formação e o que faz sentido na formação do outros. Dessa forma, o ensino religioso se apresenta não somente como uma ferramenta que amplia o conhecimento cultural do educando (uma vez que a religião caminha junto com a formação sócio/cultural), mas também se mostra hábil no desenvolvimento da aceitação do 
outro, com suas crenças e vivencias, contribuindo, assim, para a construção de uma sociedade que respeite as diferenças e aprenda a conviver com elas.

Não obstante, a inclusão irrefletida pode produzir refluxos no processo de criação de compreensão da diferença, como demonstra Miranda, Correa e Almeida (2017, p. 14) a respeito da redefinição das práticas escolares no Rio de Janeiro. Apontam os autores que, "as aulas de ensino religioso [...], justificados pela necessidade de formar integralmente a 'pessoa humana' e fazer um resgate da contribuição do 'povo negro' na sociedade brasileira, geraram uma série de resistências durante as aulas e fora delas", o que demonstra a necessidade de ampliação das ferramentas de equacionamento dos conflitos sócio-políticos decorrentes das identidades religiosas.

\section{2 - A mediação como mecanismo auxiliar na construção do respeito às diferenças religiosas nas escolas}

A BNCC (CNE, 2017, p. 434) aponta a pesquisa e o diálogo como os princípios mediadores e articuladores que tornam possível o desenvolvimento de competências específicas, que, no caso do ensino religioso seriam o combate a intolerância, a discriminação e a exclusão. Disso decorreu a ideia de inserir no contexto escolar, junto com o ensino religioso, uma ferramenta que poderá facilitar tanto a adesão dos alunos quanto o desenvolvimento das habilidades pretendidas com o ensino religioso, qual seja, a mediação de conflitos no ambiente escolar.

Vale dizer que a mediação no ambiente escolar não é uma ideia nova.Possato et al. (2016, p. 358) destacam, citando Alzate (1999), que a mediação escolar ganha destaque na década de oitenta do século passado, nos Estados Unidos, através da atuação de centros de mediação criados na década anterior para auxiliar na solução de conflitos decorrentes de disputas no contexto escolar, geralmente relacionadas a discriminação étnico-racial, eventualmente culminando em violência. Os mesmos autores ressaltam que o Brasil tem um histórico de políticas públicas que buscaram, na década de noventa do século passado, suplantar contextos de violência escolar (Possato et al., 2016, p. 363). Logo, a proposta aqui desenvolvida, visa apropriar-se dessa perspectiva para aplica-la a contextos específicos de conflitos religiosos. 
A mediação de conflitos pode ser definida ${ }^{5}$ como uma forma de solucionar conflitos na qual uma terceira pessoa, denominada mediador, favorece, através de técnicas, a tomada de decisão das partes, colaborando para que os envolvidos reconheçam seus interesses na disputa, e, assim, encontrem caminhos que levem a uma transformação, administração ou resolução do conflito.Em outras palavras, a mediação é um processo no qual as partes, como o auxílio do mediador, podem tomar uma decisão sobre o futuro do conflito e da relação entre elas.

A mediação como técnica específica de solução de conflitos, no ocidente, passou a ser delineada a partir do século XX, momento no qual se tornou uma profissão. Sua expansão se deu sobretudo pelo

[...] reconhecimento mais amplo dos direitos humanos e da dignidade dos indivíduos, à expansão das aspirações pela participação democrática em todos os níveis sociais e políticos, à crença de que um indivíduo tem o direito de participar e de ter o controle das decisões que afetam sua própria vida, a um apoio ético aos acordos particulares e às tendências, em algumas regiões, para maior tolerância à diversidade. (Moore, 1998, p.34).

O desenvolvimento dessa técnica, no Brasil, como ferramenta concreta, está diretamente ligado ao Poder Judiciário, visto que foi através da Resolução 125/2010 do Conselho Nacional de Justiça(Azevedo, 2016) que ela passou a ser fomentada e, via de consequência, estudada em larga escala no país. Contudo, a mediação não é um mecanismoexclusivamente jurídico, sendo permeada por vários outros saberes, o que a define como técnica interdisciplinar cuja utilização ultrapassa os limites dos conflitos judiciais e do ambiente do Poder Judiciário.

A construção e desenvolvimento teórico da mediação legou um conjunto de modelos diferentes ${ }^{6}$, cuja detalhamento foge ao intuito do presente trabalho. A despeito disso,

\footnotetext{
${ }^{5}$ A lei 13.140/15, que dispõe sobre a mediação como meio de solução de controvérsias entre particulares e sobre a autocomposição de conflitos no âmbito da administração pública, traz o conceito legal no primeiro parágrafo do primeiro artigo: "Considera-se mediação a atividade técnica exercida por terceiro imparcial sem poder decisório, que, escolhido ou aceito pelas partes, as auxilia e estimula a identificar ou desenvolver soluções consensuais para a controvérsia".

${ }^{6}$ Em linhas muito gerais, o mais antigo modelo de mediação é denominado tradicional linear e objetiva a construção de um acordo, não prevendo a manutenção da discórdia após o processo de mediação. Foi desenvolvido pela Escola de Harvard, e "consiste em dois ou mais indivíduos que se comunicam, um expressando seu conteúdo enquanto o outro escuta [...], a função do mediador é ser um facilitador da comunicação, de modo a conseguir o diálogo" (Oliveira e Spengler, 2013, p. 89). Já o modelo transformativo "de Bush e Folger fundamenta-se na comunicação, sem deixar de dar atenção ao aspecto relacional [...] não se centra somente em conseguir acordo" (idem, p. 90), busca o empoderamento das partes para que se reconheçam mutuamente como coprotagonistas do conflito. Além desses, "o modelo circular-narrativo de Sara Coob está baseado na comunicação circular, entendida como um todo", ampara-se em "técnicas da teoria da comunicação e da terapia familiar" (idem. ibidem), admitindo o acordo como consequência importante do processo, sem que seja o objetivo principal. Por fim, o modelo waratiano, que tem tido aplicação para a mediação de conflitos em
} 
é possível afirmar que mediação tem como base a abordagem do conflito como algo natural, neutro, ou seja, o conflito não é bom ou mau, apenas é. A forma de tratamento do conflito é que determinará seu resultado - positivo/negativo, construtivo/destrutivo. Suáres, citado por Resende e Ramos Júnior, amparado nos estudos da física, reafirma essa percepção:

Desde as descobertas do físico Werner Heisenberg (1901-1976) — este, ao perceber que no mundo subatômico os fenômenos se modificam a partir do instrumento de medida utilizado (princípio da incerteza) 6 - ou seja, da relação que o observador estabelece com o objeto observável, não é mais possível cientificamente pensar que nós, seres humanos, temos acesso as coisas tal como elas são, ou seja, a uma realidade objetiva. Pelo contrário, os estudos da física nos mostraram que seres humanos só podem ter acesso à realidade a partir das nossas percepções ou dos nossos pontos de vista. (Suáresapud Resende e Ramos Júnior, 2017, p. 118).

Aqui abordaremos a visão mais transformativa da mediação, desenvolvidas pelos autores Robert Bush e Joseph Folger:

Pode-se afirmar que não somente a meta da transformação possui uma importância original; mas também é uma meta que só pode ser alcançada graças ao processo de mediação. Há uma razão suplementar para considerar a transformação como meta principal da mediação. Outros processos de resolução de disputas, por exemplo, a adjudicação ou a arbitragem, provavelmente podem executar um trabalho eficaz como a mediação, até mesmo melhor se tratar de satisfazer necessidades ou assegurar a igualdade. Mas, pela própria natureza de seu funcionamento, estes processos são menos capazes que a mediação (se é que possuem alguma capacidade) de promover as partes litigantes mais força, mais compaixão, e, portanto, são menos capazes de alcançar o crescimento moral e a transformação. (Tradução livre; Bush e Folger, 1996, p. 61-62)

Os conflitos, assim, fazem parte da estrutura social, uma vez que as visões, sentimentos, crenças, posturas, condutas e culturas humanas são diversas. Eliminar, pois, o conflito, seria eliminar a própria essência do humano, que é ver o mundo a partir de seu ponto de vista, de sua vivência. E isso é impossível de ser unificado de forma absoluta. O papel da mediação é fazer com que as pessoas possam conviver com essas distinções; na mediação há a busca pelo consenso de maneira que casa parte envolvida possa ter sua necessidade e interesse suprido sem que isso signifique a eliminação ou a sujeição do outro. O mediador tem a função de levar às partes a uma reflexão sobre seus próprios interesses e pontos de vistas e sobre os interesses e pontos de vista do outro. Na mediação não há verdade absoluta, mas verdades que podem coexistir. A mediação estimula uma solução criativa dos conflitos, solução essa que é construída pelas partes.

comunidades populares e periferias, "conhecido como terapia do amor, propõe mediar com base na psicoterapia do reencontro ou do amor perdido" como forma de concretização da autonomia e do "crescimento por meio do conflito", auxiliando as pessoas a compreender com serenidade seus conflitos (idem, p. 91). 
Podemos afirmar que a mediação tem por fundamento a construção de uma sociedade mais responsável e tolerante, uma vez que no processo de mediação as partes tomam para si a responsabilidade da solução do conflito, não delegam a solução para um juiz que irá dizer quem está certo ou errado. Por isso, as partes acabam por perquirir sobre seus interesses e os da outra parte para que consigam saber qual o futuro a partir daquele conflito. A tolerância advém de uma lógica social que é muito trabalhada na mediação que é a da interdependência dos sujeitos e da necessidade de cooperação.

A mediação é um método de solução de conflitos que tem como pressuposto uma relação entre as partes, seja uma relação que já existe e que se quer manter ou não se pode dissolver; seja uma relação que ser quer construir. Assim, as partes que não podem ou não querem interromper em definitivo o seu relacionamento têm na mediação um lugar seguro para tomarem uma decisão sobre o conflito.

Com o advento, no Brasil, em 2015, da Lei da Mediação (Lei 13.140/15) e do Novo Código de Processo Civil (Lei 13.105/15), construiu-se o arcabouço normativo mínimo de aplicação da técnica, seja na esfera judicial, seja esfera extrajudicial, legitimando a mediação como procedimento seguro e eficaz na solução de conflitos.

Algumas observações quanto aos pressupostos da mediação são importantes. Primeiro, ela está pautada por dois princípios essenciais. Um é a voluntariedade ${ }^{7}$, em razão dos qual as partes só será possível a utilização da técnica se as partes optarem livremente por participarem da mediação e sua permanência decorre do interesse delas no processo de resolução do conflito, visto que "os litigante não são obrigados a negociar, mediar ou fazer acordo influenciados por nenhuma parte interna ou externa à disputa” (Moore, 1998, p.31). Como dito, a mediação é um processo que auxilia na tomada de decisão, a parte pode, durante o procedimento, perceber que o melhor é seguir outro caminho, se retirando da mediação e dando novos rumos ao conflito e à relação com a outra parte.

Outro princípio é a confidencialidade ${ }^{8}$ que submete todos os participantes do procedimento: as partes, o medidor e quem mais venha a integrá-lo.Isso garante que as partes possam ali expor seus pensamentos sem receio do uso das informações. O espaço da mediação é de segurança, as partes podem tratar assuntos que em outro ambiente geram vinculação e responsabilidade. A confidencialidade permite, assim, um diálogo franco e sincero entre as partes (Jablkowski e Gonzáles, 2011, p. 78).

\footnotetext{
${ }^{7}$ Artigo $2^{\circ}$, V e $\S 2^{\circ}$ da Lei $13.140 / 2015$.

${ }^{8}$ Artigo $2^{\circ}$, VII, e Art. 30 da Lei 13.140/2015. Exceção à confidencialidade está no "art. 30, § $3^{\circ}$ : não está abrigada pela regra de confidencialidade a informação relativa à ocorrência de crime de ação pública".
} 
A segunda observação é que a mediação não é a ferramenta para qualquer obra. Nem todos os conflitos são mediáveis, em muita medida pela percepção das próprias partes. Ou seja, se as partes não acreditam que a ambas possam sair atendidas daquele conflito, preferindo a competição à cooperação, não há como permaneceram na mediação. Se o objetivo é ter uma visão adversarial, de eliminação do outro, a mediação não faz sentido.

(...) conflito é determinado pelo que é valorizado pelas partes conflitantes e por quais crenças e percepções elas detêm. Mas valores, crenças e percepções nem sempre são inalteráveis. Além disso, há poucas circunstâncias, particularmente se a situação é repetitiva ou se os participantes estão envolvidos em muitos relacionamentos diferentes juntos, que sejam tão rigidamente estruturadas de maneira que o ganho de um venha inevitavelmente das perdas do outro. É, evidentemente, verdade que os participantes podem, de imediato, definir uma ocasião que permite ganho mútuo como uma situação de conflito puro e agirem uma para outra de uma forma puramente competitiva. (Deutsch, s.p., 2004)

A terceira e última observação refere-se à aplicabilidade da mediação em contextos de violência direta.Quando a relação entre as partes envolve episódios de violência, essa deve ser interrompida e somente após isso é que se pode cogitar da mediação para o caso. Aqui cabe falar tanto em violência de ordem física quanto psicológica e emocional. $\mathrm{Na}$ mediação, é de suma importância que as partes possam ter autonomia na sua tomada de decisão, que elas possam se sentir seguras, se há violência que impeça a livre manifestação de vontade não há essa possibilidade. Isso se infere do princípio de voluntariedade. A parte não é obrigada a participar/permanecer na mediação ${ }^{9}$, $\operatorname{logo}$, se não se sente segura não há motivo para estar na mediação.

Não obstante, a violência concreta não é propriamente óbice para a mediação, apenas uma questão prejudicial. Dito de outra forma, a violência concreta impede o diálogo, mas a cessação da violência concreta não faz cessar o conflito e abre a possibilidade para as práticas da mediação. E embora, nesses contextos, a mediação extrajudicial como processo técnico de solução de conflitos não possa ser continuada, as técnicas de mediação e negociação mantém sua relevância.

\footnotetext{
${ }^{9}$ A mediação extrajudicial funciona a partir de convite, a parte interessada convida a outra para mediação. Esta, por sua vez, pode não comparecer, sem ter qualquer prejuízo; exceto se a mediação foi contratualmente prevista. Neste caso, a parte convidada deverá comparecer na primeira seção, sendo que sua ausência poderá gerar multas (artigos 21 e 22 da Lei 13.140/2018). No caso processual cível, a parte pode manifestar seu desejo pela realização ou não de mediação, sendo sua manifestação apreciada pelo juiz. No processo criminal a mediação não está legalmente prevista, mas há defensores da sua utilização: "Neste contexto, a mediação tem se destacado como meio alternativo de reação e resolução do conflito, capaz de instituir censura ao ofensor e reintegrá-lo à sociedade de modo que não seja socialmente estigmatizado ou rotulado pejorativamente, ao passo que também fortalece a presença da vítima, como sujeito e não como prova, no imaginário processual e no coletivo social [...] Em relação à vítima, esta encontrará espaço para exprimir a sua versão do episódio e seus interesses, podendo participar ativamente da construção do desfecho do caso ao expor satisfatoriamente suas expectativas. 87 Quanto ao agressor, possibilitará que perceba as consequências do ato praticado (processo de responsabilização) não só no que concerne à vítima, mas também a sua relação com ela, podendo não mais praticá-lo, o que permite prevenir a prática do delito sexual e restaurar os laços sociais.” (Souza, 2016, p.11 e 12)
} 
Em resumo a mediação é uma técnica que busca a solução dos conflitos sob uma perspectiva de valorização do indivíduo e da sua capacidade de encontrar as soluções que de atendem aos seus interesses, sem estabelecer com a outra parte uma relação competitiva adversarial, mas sim colaborativa, sem que haja renúncia ou submissão (Canezin, Canezin e Cachapuz, 2017, p.303). Essa técnica pode ser aliada ao ensino religioso em meio a uma sociedade que sofre com a intolerância religiosa. A mediação no ambiente escolar tem como pretensão levar para a escola o olhar da mediação em relação ao conflito. $\mathrm{Na}$ escola a mediação surge como uma transformação da mente de toda a comunidade escolar, os responsáveis pelas crianças/jovens, os funcionários, os professores, os educandos, todos são trazidos para as transformações propostas pela mediação.

$[\mathrm{N}]$ o contexto escolar, o método da mediação pode ser utilizado para a abordagem de conflitos interpessoais. Por sua vez, as bases filosóficas em que se sustenta, tanto como seus princípios e ferramentas a tornam um caminho ótimo para capacitar seus integrantes em habilidades para o manejo pacífico dos conflitos" (Jablkowski e Gonzáles, 2011, p. 85).

Em cartilha desenvolvida pela Prefeitura do Rio, no ano de 2002 (Projeto Escola de Mediadores, 2002), que podemos apontar como exemplo de estruturação de mediação escolar, o primeiro passo de atuação na escola é a sensibilização que consiste em palestras feitas a toda comunidade escolar com o objetivo de uma transformação para além dos muros da escola. $\mathrm{O}$ resultado final de todo projeto de mediação na escola é a capacitação dos alunos e professores para a solução dos conflitos escolares por meio da mediação. Mudar a lógica punitiva/repressiva, que existe no Estado e na escola como forma de resolução de conflitos, para a lógica do respeito/cooperação. A escola assume, assim, novos contornos:

\footnotetext{
A partir dessa visão, a escola palco de tantos conflitos, o que na visão da mediação não é algo negativo, mas uma oportunidade, poderá se transformar para desempenhar inúmeras novas tarefas, quais sejam: trabalhar e questionar a multiplicidade dos valores culturais; a legitimidade das informações que chegam via inovações tecnológicas; formar indivíduos com inteligência mais crítica; fomentar autonomia dos alunos; estimular a criatividade; treinar a cooperação e a colaboração entre colegas; trabalhar pela construção de autoridade para além das relações de comando e controle, estimulando a compreensão da função das leis; fomentar o respeito pelos direitos humanos; questionar valores impostos pelo mercado e meios de comunicação; questionar padrões de beleza impostos pela mídia; problematizar a violência; repensar o papel do conflito nas relações sociais, treinar habilidades para lidar com as diferenças, dentre outras funções. (Resende eRamos Júnior, 2017, p.120)
}

A intolerância religiosa é, sobretudo em relação às religiões de matriz africanas, um conflito que age de fora para dentro das escolas, ou seja, os educandos trazem de casa suas crenças e o rechaço pela crença do outro. Quando o professor visa a introdução 
de um ensino religioso laico, nos moldes na BNCC, encontra nesse educando uma barreira que advém do preconceito e dos conflitos que ele vivencia com crenças diferentes das suas.

\begin{abstract}
A experiência do professor do ER é sempre instigante, encontramos pessoas que sofrem terrivelmente com palavras descomprometidas com a verdade, com injúrias. $\mathrm{O}$ descaso com alunos que assumem suas crenças religiosas de matrizes africanas como Candomblé e Umbanda é grande. Quando exploradas em sala de aula sempre ouvimos termos pejorativos, desrespeitosos. Trabalhar a cultura africana não é fácil e em termos religiosos essa dificuldade aumenta. $\mathrm{O}$ meio em que o aluno vive reflete em sala de aula com o desrespeito entre eles mesmos. Daí entra a mística do Ensino Religioso.[...] Buscamos resgatar a aquisição de valores tão esquecidos em nosso meio, principalmente a tolerância, pois a realidade dos nossos alunos é cruel, desumana que muitas vezes os fazem perderem o respeito por eles mesmos, a fé, a esperança. São jovens morrendo muito cedo e o Ensino Religioso é um trabalho de conquista que não acontece de um dia para o outro, num passe de mágica, se dá lentamente. (Sousa, 2010, p.4).
\end{abstract}

A mediação possui ferramentas ${ }^{10}$ que conduzem à comunidade escolar para uma nova visão do outro e de si, das quais merecem destaque:

1. Projeção para o futuro: os relatos das partes sobre o passado são importantes para compreender a história de vida das partes e para a busca de uma ressignificação, bem como para a busca de revalorização. Essa técnica faz com que as partes foquem no futuro e identifiquem o que querem que aconteça dali para frente, para que elas possam desenhar uma nova história;

2. Validação de sentimentos: validar sentimentos não é concordar com aquilo que as partes sentem, não é dar razão, mas identificar e reconhecer aquilo que é sentido. Reconhecer o que as partes sentem diante da relação conflituosa e abordá-los de forma natural, sem juízo de valor, como algo legítimo possibilita a sensação de acolhimento. Com a validação é possível, também, compreender os interesses das partes.

3. A inversão de papéis consiste no exercício de uma parte se colocar no lugar da outra, com essa técnica pretende-se estimular a empatia entre as partes. Perceber o conflito sob o ponto de vista do outro auxilia na reflexão da parte sobre o outro e sobre si mesma.

Todas as técnicas brevemente citadas são manejadas pelo mediador com cuidado e em momentos nos quais se encontra em reuniões individuais com uma das partes ${ }^{11}$.

\footnotetext{
${ }^{10}$ Ferramentas listadas a partir do Manual de Mediação formulado do CNJ (Azevedo, 2016).
} 
E essas especificamente aqui destacadas trabalham a visão da parte sobre si e sobre o outro, reforçando o aspecto transformativo que se pretende com a mediação escolar.

\begin{abstract}
As cenas colaborativas são um meio pedagógico ótimo para a configuração de espaços no quais todos ensinamos e todos aprendemos a conviver. Nelas, se coloca em jogo e se pode desenvolver competências sociais requeridas para a convivência, se estimula uma nova consciência sobre os modelos de vínculos estabelecidos e circulam conhecimentos que facilitam a chegada a novos significados para encarar de forma eficaz a vida em comunidade. (Jablkowski e Gonzáles, 2011, p. 45).
\end{abstract}

Vale dizer, para além do que foi dito, que a convergência entre ensino religioso e mediação em contextos de conflitos de visões de mundo na escola poderia dar-se em três frentes distintas e não excludentes, cujo desenvolvimento não cabe no âmbito deste trabalho. Uma primeira possibilidade seria agregar à formação do professor de ensino religioso, para além das competências e habilidades decorrentes da formação em ciência da religião, que lhes garantiriam a capacitação para lidar com a multiplicidade de visões de mundo, sem conduzir a formação do aluno por uma perspectiva limitada, também a capacitação técnica - mediante formação específica - para lidar com conflitos decorrentes do confronto direto entre essas visões de mundo, no ambiente escolar. Uma segunda hipótese seria a formação de equipes auxiliares, dentre os profissionais da educação que trabalhem nas escolas, habilitando-as a utilizar técnicas de solução de conflito nesses contextos. Por fim, e como medida mais incisiva, o estabelecimento de mediações extrajudiciais por profissionais de mediação habilitados, nos contextos e casos mais difíceis de intolerância religiosa na escola.

\title{
Considerações finais
}

O ensino religioso proposto pela BNCC tem como foco a abordagem da religião de forma laica levando aos educandos a compreender o campo religioso brasileiro, a diversidade de crenças, gerando reconhecimento do outro e de si mesmo. Em um contexto com intolerância religiosa, o ensino religioso encontra barreiras na adesão dos educandos e na forma como se comportarão diante da matéria. Dois fatores que contribui negativamente para esse processo são a normalização das diferenças e a negação de sua condição constitutiva do indivíduo.

\footnotetext{
$11 \mathrm{Na}$ mediação é possível ter sessões/reuniões com as partes que estão em conflito conjuntamente ou
} separadamente, nas chamadas sessões privadas. 
A mediação como técnica dialógica de solução de conflitos, que valoriza a cooperação, quando inserida no ambiente escolar,traz novas competências a habilidades que podem contribuir para todo o ambiente escolar, incluindo (e sobretudo) o ambiente de desenvolvimento do ensino religioso. Em lugares onde as pessoas respeitama diversidade de visões de mundo, o ensino religioso será visto como uma oportunidade transformação das relações e de crescimento. Nesse diapasão, as técnicas de resolução de conflito, devidamente difundidas para todos os envolvidos no contexto da escola, traz uma perspectiva de evolução da convivência e de otimização na resolução das disputas.

\section{Referências bibliográficas}

AZEVEDO, André Gomma de (Org.). Manual de Mediação Judicial. Conselho nacional de

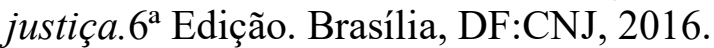

BRASIL. Constituição da República Federativa do Brasil, de 05 de outubro de 1988. Disponível em: http://www.planalto.gov.br/ccivil_03/constituicao/constituicaocompilado.htm. Acesso em: 01/11/2018.

BRASIL. Lei 9.394, de 20 de dezembro de 1996. Estabelece as Diretrizes e Bases da Educação Nacional.Disponível em: http://www.planalto.gov.br/ccivil_03/LEIS/L9394.htm. Acesso em: 01/11/2018.

BRASIL. Lei $n^{\circ} 13.105$, de 16 de março de 2015. Código de Processo Civil.Disponívelem: $<$ http://www.planalto.gov.br/ccivil_03/_ato2015-2018/2015/lei/113105.htm>. Acesso em: 01/11/2018.

BRASIL. Lei $n^{\circ} 13.140$, de 26 de jumho de 2015. Dispõe sobre a mediação entre particulares como meio de solução de controvérsias e sobre a autocomposição de conflitos no âmbito da administração pública.Disponível em: http://www.planalto.gov.br/ccivil_03/_Ato20152018/2015/Lei/L13140.htm. Acesso em: 01/11/2018.

BURITY, Joanildo. Cultura e identidade no campo religioso. Estudos Sociedade e Agricultura, n. 9, outubro de 1997. p. 137-177. Disponível em: http://bibliotecavirtual.clacso.org.ar/ar/libros/brasil/cpda/estudos/nove/burity9.htm. Acesso em: 18/11/2018.

BUSH, Robert A. Baruch; FOLGER, Joseph P. La Promesa de La Mediacion: como afrontar elconflicto mediante la revalorizacions e o reconocimento, Trad. Aníbal Leal. Espanã: EdicionesGranica S.A.,1996.

CANEZIN, Thays Cristina Carvalho; CANEZIN, Claudete Carvalho; CACHAPUZ, Rozane da Rosa. Mediação nos Casos de Violência contra a Mulher. Revista do Direito Público, Londrina, v.12, n.1, p.287-310, mai.2017.

CAVALCANTI M.T., Juliana B. Pelo ensino das religiosidades. Reflexões sobre o ensino religioso e sobre o silêncio dos historiadores e cientistas sociais. In: SANTOS, BabalawôIvanir dos et al. (orgs.). Intolerância religiosa no Brasil: relatório e balanço = Religiousintolerance in Brazil: reportaccount. CEAP - Centro de Articulação de Populações Marginalizadas. Edição bilíngue. Rio de Janeiro: Klíne: CEAP, 2016. p. 69-81. Disponível em: $\quad$ https://www.geledes.org.br/wp-content/uploads/2018/08/relatorio-final-port-2.pdf. Acesso em: 19/11/2018. 
CNE. Conselho Nacional de Educação. Conselho Pleno. Resolução CNE/CP 2/2017. Institui e orienta a implantação da Base Nacional Comum Curricular, a ser respeitada obrigatoriamente ao longo das etapas e respectivas modalidades no âmbito da Educação Básica. Diário Oficial da União, 22 de dezembro de 2017, Seção 1, pp. 41 a 44. Brasília, DF, 2017.

Disponível em: http://portal.mec.gov.br/index.php?option=com_docman\&view $=$ download\&alias $=79631$ rcp002-17-pdf\&category_slug=dezembro-2017-pdf\&Itemid=30192. Acesso em: 01/11/2018. CUNHA, Luiz Antônio. A entronização do ensino religioso na base nacional curricular comum. Educação \& Sociedade [online], n. 37. Jan-Mar. 2016. Disponível em: http://www.redalyc.org/articulo.oa?id=87346374015. Acesso em 19/11/2018.

CUNHA, Luiz Antônio. Hegemonia e confronto na produção da segunda LDB: o ensino religioso nas escolas públicas.Pro-Posições, Campinas, v. 25, n. 1, p. 141-159, Apr. 2014 .Disponível em: http://www.scielo.br/scielo.php?script=sci_arttext\&pid=S010373072014000100008\&lng=en\&nrm=iso. Acesso em: 23/11/2018.

DEUTSCH, Morton. A resolução do conflito. Trad. OLIVEIRA, Arthur Coimbra de.In: AZEVEDO, André Gomma de (org.). Estudos em Arbitragem, Mediação e Negociação Vol. 3. Brasília: Grupos de Pesquisa, 2004. Disponível em http://www.arcos.org.br/livros/estudosde-arbitragem-mediacao-e-negociacao-vol3/parte-ii-doutrina-parte-especial/a-resolucao-doconflito. Acesso em: 01/11/2018.

IBGE. Censo 2010: número de católicos cai e aumenta o de evangélicos, espíritas e sem religião, 2012. Disponível em: https://censo2010.ibge.gov.br/noticiascenso id $=3 \&$ idnoticia $=2170 \& v i e w=$ noticia. Acesso em: 01/11/2018.

JABLKOWSKI, Gabriela Irina; GONZÁLES, Guillermo Mario. Configurando escenas colaborativas em La escuela: aportes y experiências de mediación y diálogos facilitados. Buenos Aires: 12ntes, 2011.

MDH. Ministério dos Direitos Humanos. Combate à intolerância e ao racismo religioso são pautas prioritárias do $M D H, 2017.2$ Disponível em: http://www.mdh.gov.br/sdh/noticias/2017/outubro/combate-a-intolerancia-e-ao-racismoreligioso-sao-pautas-prioritarias-do-mdh. Acesso em 01/11/2018.

MIRANDA, Ana Paula Mendes de; CORRÊA, Roberta de Mello; ALMEIDA, Rosiane Rodrigues de. Intolerância religiosa: a construção de um problema público. Intolerância Religiosa 2(1), jul-dez de $2017 . \quad$ Disponível em: https://app.uff.br/riuff/bitstream/1/6095/1/ana-paula-miranda_roberta-corrc3aaa_rosiane-dealmeida_intolerc3a2ncia-religiosa_a-construc3a7c3a3o-de-um-problema-pc3bablico.pdf. Acesso em: 18/11/2018.

MOLINA, Danilo. Intolerância Religiosa e consciência negra. Brasil 247, 20/11/2018. Disponível em: https://www.brasil247.com/pt/colunistas/danilomolina/375531/Intoler\%C3\%A2nciaReligiosa-e-consci\%C3\%AAncia-negra.htm. Acesso em: 20/11/2018.

MOORE, Christopher W. O processo de mediação: estratégias práticas para a resolução de conflitos. Trad. Magda França Lopes. 2 ed. Porto Alegre: Artmed, 1998.

MOUFFE, Chantal. Democracy, powerandthe "Political". In: BENHABIB, Seyla (ed.). Democracyanddifference: Contestingtheboundariesofthepolitical.Princenton (UK): Princeton University Press, 2016. p. 245-256.

OLIVEIRA, LuthyanaDemarchi de; SPENGLER, Fabiana Marion. O Fórum Múltiplas Portas como política pública de acesso à justiça e à pacificação social. [Recurso digital]. Curitiba:Multideia, 2013.

POSSATO, Beatris Cristina; RODRIGUEZ-HIDALGO, Antonio; ORTEGA-RUIZ, Rosario; ZAN, Dirce Djanira Pacheco e. O mediador de conflitos escolares: experiências na América Latina. Psicologia Escolar e Educacional. Psicol. Esc. Educ., Maringá , v. 20, n. 2, p. $357-$ 
366 ,

Aug.

2016.

Disponível

em:

http://www.scielo.br/scielo.php?script=sci_arttext\&pid=S1413-

85572016000200357\&lng=en\&nrm=iso. Acessado em: 24/11/2018.

PROJETO ESCOLA DE MEDIADORES. Cartilha de mediadores: como montar esse projeto na minha escola. Disponível em: http://www.cnmp.mp.br/conteate10/pdfs/tema4_cartilhamediadores.pdf. Acesso em: 01/11/2018.

RESENDE, Flávia Vieira de; RAMOS JÚNIOR, Ronan. A Mediação Pode Ser Uma Resposta aos Conflitos nas Escolas. In: DUARTE, Fernanda; IORIO FILHO, Rafael Mario; FELIPE, Ana Paula Faria; MEIRELLES, Delton. (coordenadores).Mediações: práticas, discursos e reflexões. [Recurso digital]. Niterói: PPGSD — Programa de Pós-graduação em Sociologia e Direito, 2017.

RESK, Felipe; TOMAZELA, José Maria; COTRIM, Jonathas. Brasil registra uma denúncia de intolerância religiosa a cada 15 horas. O Estado de São Paulo, São Paulo, 12/11/2017. Disponível em: https://brasil.estadao.com.br/noticias/geral,brasil-registra-uma-denuncia-deintolerancia-religiosa-a-cada-15-horas,70002081286. Acesso em: 01/11/2018.

RODRIGUES, Elisa. Questões Epistemológicas do Ensino Religioso: uma proposta a partir da Ciência da Religião. Interações - Cultura e Comunidade, Belo Horizonte, Brasil, V.8 N.14, P.230-241, JUL./DEZ.2013.

SANCHIS, Pierre. Religião, cultura e identidade: matrizes e matizes. [Recurso digital].Petrópolis, RJ: Vozes, 2018.

SANTOS, BabalawôIvanir dos; NASCIMENTO, Maria das Graças O.; CAVALCANTI M. T., Juliana B.; GINO, Mariana (organizadores). Intolerância religiosa no Brasil: relatório e balanço $=$ Religiousintolerance in Brazil: reportaccount. CEAP - Centro de Articulação de Populações Marginalizadas. Edição bilíngue. Rio de Janeiro: Klíne: CEAP, 2016. Disponível em: $\quad$ https://www.geledes.org.br/wp-content/uploads/2018/08/relatorio-final-port-2.pdf. Acesso em: 19/11/2018.

SANTOS, Luzinete Rodrigues dos; FARIA, Michelle Lopes; OLIVEIRA,Nilmair Machado de; DADA, Pollyana Patrícia; FERREIRA, Sheilla Letícia de Castro; CARVALHO, Vanessa Pereira de; RIBEIRO, Vívian Souza; SANT’ANNA, Vera Lúcia Lins (orientadora). A Educação Religiosa no ensino fundamental: desafios e perspectivas à prática docente. Pedagogia em Ação, v. 1, n. 1, p. 1-141,jan./jun. 2009 - Semestral 99.

SOARES, Afonso Maria Ligorio. A contribuição da Ciência da Religião para a formação de docentes ao Ensino Religioso. Revista de Estudos da Religião (REVER), Vol. 15, №. 2, 2015. p. 45-54. Disponível em: https://dialnet.unirioja.es/descarga/articulo/5294038.pdf. Acesso em: 18/11/2018.

SOUSA, Francisca Roseane Franco Ribeiro de. Ensino Religioso Na Educação Escolar: Intolerância Contra Religiões Afro-Brasileiras. Cadernos Imbondeiro. João Pessoa, v.1, n.1, 2010.

SOUZA, Bárbara FachinelliNishi de. $O$ uso da mediação nos delitos sexuais: o resgate da dignidade da vitima. Revista Brasileira de Ciências Criminais, Vol. 125, novembro 2016. 


\title{
As Religiosidades e a Consciência Histórica: Leituras da Lei Mosaica entre os Estudantes de Santos Dumont - MG
}

\author{
Religiosities and Historical Consciousness: Readings of the Mosaic Law among the Students \\ of Santos Dumont - MG
}

Jorge William Falcão Junior ${ }^{12}$ williamafalcaojr@gmail.com

Resumo: Apresentaremos breves apontamentos sobre a análise que temos desenvolvido acercado conhecimento prévio, sobretudo no trato da História dos hebreus, dos estudantes do $1^{\circ}$ Ano Técnico Integrado em Eletrotécnica do Instituto Federal Sudeste de Minas GeraisCampus Santos Dumont. Partiremos de um questionário queaplicamosem 2018por meioGoogle Forms que objetivou identificar a maneira como os estudantes compreendem os aspectos históricos da Lei Hebraica, cuja autoria costuma ser atribuída a Moisés, e procuram nela uma aplicação para os dias atuais.Investigaremos as interferências da religiosidade, da educação religiosa promovida pelas igrejas, da educação familiar, da televisão e do ensino de História escolar na formação da consciência história dos estudantes.

Palavras-Chaves: Religiosidade; Consciência Histórica; Instituto Federal Sudeste de Minas Gerais; Lei Mosaica; Código de Hamurabi.

\begin{abstract}
We will present brief notes on the analysis that we have developed about the previous knowledge, especially in the treatment of the History of the Hebrews, with students of the 1st Technical Year Integrated in Electrotechnology of the Instituto Federal Sudeste de Minas Gerais - Santos Dumont Campus. We will start with a questionnaire that we applied in 2018 through Google Forms that aimed to identify how students understand the historical aspects of the Hebrew Law, whose authorship is usually attributed to Moses, and look for an application to the present day. We will investigate the interference of religiosity, religious education promoted by the churches, family education, television and the teaching of school history in the formation of students' history.
\end{abstract}

Keywords: Religiosity; Historical Consciousness; Instituto Federal Sudeste de Minas Gerais; Mosaic Law; Code of Hamurabi.

\section{Apresentação e fundamentação teórico - metodológica.}

Além das Catequeses e das lições de Escolas Bíblicas Dominicais promovidas por inúmeras denominações evangélicas e, também, da educação religiosa promulgada nos lares, desde os anos 2010, a população brasileira conta com a Emissora Record que utiliza o meio de comunicação de massa para catalisar a divulgação das versões bíblicas, desde uma perspectiva da Igreja Universal do Reino de Deus, sobre a história dos Hebreus e dos povos vizinhos. Portanto, a emissora veicula informações históricas carregadas de cunho religioso apresentadas sobre forma de entretenimento para crianças e adultos.

\footnotetext{
${ }^{12}$ Doutorando em História pela Universidade Federal de Juiz de Fora.
} 
Dentre as novelas exibidas pela Record, temos: A História de Ester (2010); Sansão e Dalila (2011); “o Rei Davi (2012)”; José do Egito (2013); Milagres de Jesus (2014/2015). Além disso, a história dos “10 mandamentos" ganhou pela Emissora Record uma nova versão. Apresentada primeiramente no formato Telenovela (2015), posteriormente, exibida como filme (2016) e, por fim, uma nova temporada (2017), todos disponíveis, inclusive no serviço de streaming da empresa Netflix, e exibidos em canais pagos, como o Megapix.

De acordo com a tradição judaica, em aproximadamente 1400 a.C os 10 Mandamentos e as leis hebraicas posteriores foram organizadas por Moisés e escritas nos cinco primeiros livro da Bíblia cristã (o Pentateuco ou Torah). Outra data provável é a de 1250 a.C. A autoria deste conjunto de livros também é muito controversa para a historiografia e para a arqueologia. Muitos, inclusive, afirmam que não é possível identificar uma unidade entre estes livros, embora se tratem de textos escritos por diversos autores de tempos distintos e compilados muito posteriormente. Ainda no século XIX, os teólogos da Alta Crítica (WELLHAUSEN), por exemplo, afirmaram que o pentateuco utilizado pelos Judeus atualmente foi compilado e organizado depois do cativeiro da babilônia (538a.C) e é composto por quatro tipos de documentos escritos (Eloísta, Javista, Deuteronomista e Sacerdotal) e de outros preservados a partir da tradição oral. As leis presentes no Pentateuco que possuímos, por sua vez, podem ser divididas em: o decálogo (a lei moral resumida nos 10 Mandamentos), o Código da Aliança (aliança de Deus com o povo hebreu no Monte Sinai, incluindo o Direito Civil e Criminal), o Deuteronômio (um conjunto de leis variadas foram compiladas provavelmente depois da queda de Smaria), o Código de Santidade e o Código Sacerdotal (leis sobre os sacrifícios, ritual de consagração dos sacerdotes, e lei de pureza). Outra divisão utilizada, segue a tradição das igrejas protestantes, segundo a qual a Lei Mosaica pode ser dividida em: Moral, Cerimonial e Civil (VAUX, 2017. P.176 - 177). Os traços de continuidade das leis morais e civis foram disputados pelos teólogos ao longo da História da Igreja, uma vez que não houve consenso sobre quais valores morais poderiam ser considerados supratemporais e quais princípios das Leis Civis deveriam continuar valendo para as nações cristãs (FEINBERG, 2013). Não podemos, contudo, pressupor que os usos da Lei Mosaica são precedidos por uma apurada reflexão filosófica ou teológica. Apesar disso, a Lei continua sendo aplicada cotidianamente tanto por pessoas comuns em suas vidas privadas como por políticos em contextos públicos, sendo portanto, um elemento significativo da constituição das consciências históricas.

Quando falando de consciência histórica, tomamos como fundamento a teoria da Didática da História proposta por JornRusen, que aponta a existência de pelo menos quatro 
tipos: a tradicional, a exemplar, a crítica e a genética. Cada uma destas consciências apresentam relações distintas com a memória, com a continuidade, com a comunicação, com a identidade e com o sentido. Na tradicional, a memória considera os relatos de origem e ordenamento do mundo como normativos para a formação a identidade e do estilo de vida contemporâneos, e o tempo é eternizado como sentido na consciência histórica. A consciência histórica exemplar tem como seu maior representante a História Magistra Vitae (mestre da vida), retirando de acontecimentos históricos casos que demonstrem regras gerais do agir. Esta consciência assume a postura de julgadora do passado e busca formar as identidades a partir da aplicação de regras a situações concretas do agir. A consciência crítica parte de uma postura questionadora em relação a memória e busca romper com as representações atuais do curso do tempo. Ou seja, ela busca uma tomada consciente de posição em contraposição a comportamentos sociais predominantes ou prescritos, recusando as formas de vida dominante e tratando o tempo, como sentido, como julgável. Por fim, a consciência genética é formada por uma ciência histórica que proporciona aos seus educandos o acesso a formas de vidas estranhas e alheias às suas próprias formas de vida, permitindo que a memória seja constituída a partir da escolha de várias possibilidades. O tempo, antes de ser julgado, é temporalizado como sentido. (RUSSEN,2007. P.1-83)

Uma vez que boa parte dos estudantes brasileiros, antes mesmo de estudarem Antiguidade Oriental nas Escolas, apresentam um conhecimento prévio sobre a História dos Hebreus e de outros povos, como os egípcios, mesopotâmicos e cananeus, buscaremos identificar o lugar da Educação Religiosa proposta pelas igrejas, pela educação familiar pela televisão, haja vista a formação do conhecimento religioso, tanto no que se refere aos conteúdos históricos como no que se refere à consciência histórica.

Assumimos como Hipótese que as Telenovelas Bíblicas e a educação instituída nas igrejas contribuem para a formação de uma consciência histórica tradicional ou exemplar; e que a educação formal, mesmo promovendo entre os estudantes um superávit cognitivo, não tem sido suficiente para promover uma consciência histórica crítica ou genética.

Como Objetivo primário, buscamos Identificar as funções da religiosidade, da educação religiosa, da educação familiar, da televisão e da escola na formação da cognição histórica (dos conceitos substantivos e epistemológicos) relativos à História dos hebreus e dos mesopotâmicos e na formação da consciência histórica dos estudantes do Instituto Federal Sudeste de Minas.

Dentre nossos objetivos secundários, pretendemos: Investigar as relações entre as identidades religiosas dos estudantes e a formação da consciência histórica, sobretudo das 
funções atribuídas ao passado e ao sagrado, a partir das aplicações dos princípios da Lei Mosaica ao mundo contemporâneo (Consciência Histórica); Identificar os pesos das telenovelas e filmes bíblicos da emissora Record, das escolas religiosas e das famílias na formulação de um conhecimento prévio dos estudantes sobre Antiguidade Oriental; Investigar, a partir da comparação de documentos, se como os estudantes concebem relações de simultaneidade entre a História dos Hebreus e Mesopotâmicos. (Cognição Histórica Conceitos Epistemológicos e Substantivos); Perceber entre os estudantes a capacidade de localização temporal(cronológica) dos eventos da História dos Hebreus e Mesopotâmicos a partir dos documentos e das suas respectivas descrições (Cognição Histórica - Conceito Epistemológico); Comparar a maneira como os livros didáticos e os documentos oficiais do Ensino de História tratam das questões religiosas e históricas relacionadas à História do povo Hebreu, sobretudo quanto ao uso da Torá enquanto documentação histórica. Compreender como os professores concebem o uso da bíblia enquanto fonte Histórica e o qual o lugar da História dos Hebreus no planejamento anual e escolar.

Aplicamos um questionário apresentado em formato digital envolvendo um número de 16 estudantes. Uma vez que os campi do Instituto Federal Sudeste de Minas dispõe de um Laboratórios de Informática, recorrermos ao Google Forms para a aplicação do questionário entre os estudantes e professor. A partir de um estudo indutivo comparativo entre um trecho do Código de Hamurabi e o Código de Leis que sucedem a Narrativa dos 10 mandamentos, os estudantes e professores foram desafiados emitirem os seus posicionamentos sobre os usos do passado ao observarem estas fontes antigas com o olhar da História enquanto ciência. Os estudantes tiveram duas aulas geminadas de 50 minutos para responder as sete partes do questionário: 1. Apresentação; 2. Conhecimento sobre a História dos Hebreus; 3. Os Hebreus e os Povos Vizinhos; 4. A diversidade literária da Bíblia; 5. Os 10 Mandamentos; 6. O Filme "Os 10 Mandamentos"; 7. Comparando os Documentos Antigos.

Para a investigação do lugar da religiosidade na formação da cognição consciência histórica dos estudantes do Instituto Federal Sudeste de Minas, aplicamos apenas um questionário de conhecimento prévio. Ou seja, não atentamos para o conhecimento adquirido na escola após a exposição do conteúdo referente à História dos Hebreus programada para o Primeiro Ano. Contudo, não desconsideramos que este conteúdo foi visto no Sexto Ano do Ensino Fundamental.

\section{A História Dos Hebreus Nos Componentes Curriculares}


De acordo com os Parâmetros Curriculares Nacionais (PNLD, 2018) as Diretrizes Curriculares de muitos Estados Brasileiros e o Conteúdo Programático de alguns Vestibulares, como a FUVEST - SP, a História do povo que deu origem à Bíblia, assim como a História dos egípcios, mesopotâmicos, persas e fenícios, participa dos conceitos substantivos, ou seja, dos conteúdos básicos pretendidos para o Ensino de História no $1^{\circ}$ Ano do Ensino Médio. Além disso, a referida matéria contempla o conteúdo programático previsto para o $6^{\circ}$ ano do Ensino Fundamental II. A despeito dos conhecimentos adquiridos em sala de aula e previsto nos componentes curriculares e nos planejamentos anuais dos professores, buscamos mapear os pesos dos diferentes locais de formação, inclusive os informais, na construção de uma cognição e consciência histórica dos estudantes $1^{\circ}$ ano do Instituto Federal do Sudeste de Minas Gerais.

Além dos objetivos almejados para os estudantes do Sexto Ano, antiga Quinta Série, os Parâmetros Curriculares Nacionais sugeriam que todo conteúdo fosse trabalho a partir do grande eixo temático "História das Relações Sociais, da Cultura e do Trabalho", subdividido, por sua vez, em dois temas: "Relações Sociais e a Natureza" e "As Relações de Trabalho". O conteúdo relativo às narrativas de origem e à História dos hebreus e dos povos vizinhos está presente dentro do primeiro subtema (PCN, P.55). Apesar do conteúdo previsto não apontar diretamente para a História dos hebreus, os PCN's destacam o conteúdo da História da Antiguidade Oriental como fundamental. Assim, desde os anos 90, o conteúdo da História dos Hebreus tem sido trabalhado nas escolas do Ensino Fundamental II. Suspeitamos, porém, que a educação escolar pouco tem avançado no intuito de capacitar aos estudantes a estabelecer relações de simultaneidade entre a História dos hebreus e dos povos vizinhos, o que, provavelmente tem acontecido pela falta de familiaridade das temáticas da História Antiga entre os professores de História brasileiros.

Apesar das críticas aos Parâmetros Curriculares Nacionais, por apresentarem uma proposta de Educação de Identidade de Gênero e Sexualidade a partir da perspectiva fundacionalista biológica, segundo a qual o gênero é uma construção elaborada em cima de um dado biológico, não podemos deixar de considerar o seu avanço no intuito de colocar em pauta do ensino da Educação Básica as reflexões acerca do respeito à diversidade identitária fundada nas distintas relações entre os corpos e as sexualidades. O documento de 1996 já contava com "Orientação Sexual” enquanto tema transversal, perpassando todas as disciplinas do Ensino Fundamental, não somente os aspectos fisiológicos explorados pelas Ciências Naturais. 
Por outro lado, ao analisarmos a Base Nacional Comum Curricular para ao Ensino Fundamental (2017), verificamos que o conteúdo de Antiguidade Oriental aparece delimitado à mesopotâmia, explorada, por sua vez, no contraste com o Egito e os povos da América "PréColombiana". O tema transversal "orientação sexual” também não apareceu na BNCC, nem como um subtema ou mesmo como um assunto isolado. $\mathrm{O}$ trato das questões relativas ao gênero e sexualidade não exploram os aspectos sócio, históricos, culturais e psicológicos, restringindo-se apenasàs questões fisiológicas. Apesar do documento não ter poder de regular as atividades rotineiras de cada escola, ele estabelece uma base para a formações dos currículos municipais e, dependendo da gestão escolar, pode impor aos professores um certo direcionamento quanto aos temas a serem tratados.Ao delegar exclusivamente à família a responsabilidade de lidar com questões relativas à gênero e sexualidade, comprometemos a formação de uma consciência histórica genética que capacite o estudante a verificar a historicidade das diversas relações com o corpo. Ou seja, privamos os estudantes de compreender outras práticas e perspectivas filosóficas a respeito do corpo e da sexualidade, restringindo as possibilidades de ação dos educandos.

\section{O Livro Didático}

A coleção de livros utilizada pelos estudantes do IF-SUDESTE MG é a História, Sociedade e Cidadania, composta por três volumes, de Alfredo Boulos Júnior. A parte referente à História dos hebreus encontra-se no primeiro volume, no mesmo capítulo da História dos fenícios e dos persas. Estabelecendo uma boa relação do presente com o passado, o autor inicia a sua narrativa apresentando os elementos da cultura judaica presentes em nosso cotidiano, como o candelabro e a Torá, também tratadas como fontes materiais e escritas. Como objetivo para o ensino deste conceito substantivo, Boulos sugere: "compreender o monoteísmo étnico" (BOULOS, 2016, p. 348). Apoiando-se em Jaime Pinsky, o autor sugere que monoteísmo ético é a "crença em um deus único, que dita as normas de comportamento e exige uma conduta ética por parte dos seus seguidores" (PINSKY, 2001, p.116).As práticas politeístas vivenciadas entre os hebreus não foram consideradas no capítulo e só podem ser presumidas por inferências.

No quadro destinado à reflexão histórica/teórica, Boulos utiliza novamente um texto do Historiador Jaime Pinskyno intuito de demonstrar que a Bíblia é fonte histórica por referirse aos costumes e valores culturais de uma determinada época e local, e não por verificarmos nela uma a verdade absoluta sobre os acontecimentos históricos da antiguidade. 
A caracterização do espaço físico e geográfico da Palestina parte das contribuições do professor de História do Oriente Próximo da Universidade de Roma (LIVERANI, 2008, p. 27 -30). No entanto, ao debater panoramicamentesobre as distintas fases da história dos hebreus, Boulos não apresenta nenhuma discussão historiográfica, ou alternativa, que nos mostre possibilidades além da cronologia e os eventos narrados na Torá. O Êxodo, por exemplo, é relatado da seguinte maneira:

Essa saída em massa dos hebreus do Egito é chamada de Êxodo (palavra de origem grega que significa "saída"). Segundo a Bíblia, foi durante uma caminhada de cerca de 40 anos que Moisés recebeu de Deus, no monte Sinai, duas tábuas com os dez mandamentos (Decálogo). (BOULOS, 2016, p.84).

Neste e em outros momentos, a narrativa bíblica é utilizada como estrutura fundamental das etapas do povo hebreu. No entanto, esse versão não é comparada com outras perspectivas historiográficas ou fontes históricas.

\section{A prática docente no campus de Santos Dumont.}

Antes de levar o questionário para os estudantes, tivemos a oportunidade de aplicar um outro questionário com o professor responsável pelo ensino do $1^{\circ}$ Ano, o qual chamaremos de Professor 01. Ele assumiu uma postura de professor/historiador que compreende o fenômeno religioso em seus aspectos históricos e culturais, buscando não comprometer a sua atividade docente com interferências da sua visão de mundo no trato das questões existenciais.

Enquanto a maior parte das escolas da região da Zona da Mata Mineira orienta o seu currículo com base no vestibular seriado da Universidade Federal de Juiz de Fora (PISM UFJF) e enfatizam apenas a antiguidade ocidental, o Professor 01 tem buscado explorar os povos da antiguidade oriental, dentre eles os hebreus. Quando perguntado sobre a importância do ensino de antiguidade oriental no $1^{\circ}$ ano do Ensino médio, ele respondeu:

\footnotetext{
"Como trabalho com História da Ciência no Ensino Médio, acredito que seja importante abordar a História da Contagem Numérica e do Tempo (Calendários) e a História da Escrita, além da História do próprio processo de construção do conhecimento humano. Entendo que a História do Oriente Próximo seja de grande importância para essa abordagem, pois também abordo o Paleolítico, o Neolítico e destaco a "Era dos Metais" (Metalurgia) nesses territórios. Discordo que os conteúdos do Ensino Médio devam começar com a História Greco-Romana. Isso fortalece uma visão eurocêntrica do processo histórico".
}

Sobre o uso do livro didático, o professor 01 afirmou que o material em questão utilizado pelos estudantes como material de suporte para leitura e realização de trabalhos. No entanto, ele não ocupa um lugar central nas aulas. Numa avaliação geral sobre o capítulo de 
História dos hebreus, o livro é tratado pelo Professor 01 como adequado, pois não faz uso de proselitismo religioso ou ideológico.

Apesar de considerar a bíblia uma fonte histórica que pode ser explorada em sala de aula de maneira crítica, o Professor 01 não a utilizou em suas aulas. Nas perguntas referentes à comparação entre a Lei Mosaica e o Código de Hamurabi, o Professor 01 desenvolveu as respostas que seguem no quadro 02 .

Quadro 01 - Lei mosaica e código de Hamurabi. Professor 01.

\section{Você considera a Bíblia uma fonte histórica? Justifique a resposta explicando o que você considera uma fonte histórica.}

R: "Fonte de estudo para a história de uma tradição religiosa, sim. Como fonte primária de um período histórico, ela deve ser confrontada e contextualizada com outras fontes históricas e arqueológicas".

É possível afirmar que os dois textos se baseiam do princípio do talião? Justifique.

R:“O Princípio do Talião baseia-se na exigência de que a pena seja proporcional ao crime cometido. Na minha visão, as punições previstas no texto referente ao Código de Hamurabi são desproporcionais aos crimes. Em relação ao texto de Moisés, me parece que as punições são mais baseadas na proporcionalidade dos crimes. Contudo, vejo que ambas seguem um mesmo princípio".

Marque a opção que expressa a sua opinião sobre as leis cuja escrita foi atribuída a Moisés:

Alternativas recusadas:

(1)Veio de Deus diretamente do céu e não tem nenhuma semelhança com os Códigos de Leis de outros povos antigos.

(2)Não veio de Deus e é semelhante aos códigos de leis de outros povos.

(3)Veio de Deus, mesmo assim é semelhante aos códigos de leis de outros povos.

(4)É semelhante aos códigos de leis de outras povos, não dependendo se veio ou não de Deus.

Alternativa construída:

(5) Outro... R: As leis e códigos morais daqueles povos são semelhantes, pois possuem bases culturais em comum.

Você concorda com a aplicação do princípio do talião atualmente? Justifique.

R: "Não, pois não há qualquer fator de correção/educação/reintegração do criminoso. Apenas punição vingativa".

\section{Conhecimento Prévios Dos Estudantes}

Dos 16 estudantes que participaram da pesquisa, $11(68,8 \%)$ moram na mesma cidade em que estudam, os outros $5(31,3 \%)$ precisam se deslocar de outros municípios. 
Quanto à faixa etária, os que possuem 15 anos são 15 estudantes $(93,8 \%)$ e apenas 1 estudante $(6,3 \%)$ tem 14 anos. A variação religiosa entre os entrevistados é representada por 1 agnóstico, 1 Kardecista, 2 ateus, 3 evangélicos/protestantes e 9 católicos. Quando perguntados se possuem religião, 75; Os que possuem a religião dos pais.

Dentre os participantes, $81,3 \%$ afirmam que a bíblia é um livro sagrado. Quando perguntamos sobre a exclusividade do caráter sagrado da bíblia, 31,3\% afirmaram que a bíblia era o único livro sagrado, outros 31,3\% afirmaram que não. Os demais 37,5\% afirmaram que talvez. Das justificativas mais elaboradas sobre cada alternativa das perguntas "Você considera a bíblia um livro sagrado? Você considera a bíblia o único livro sagrado?”, obtivemos as seguintes respostas:

\begin{abstract}
Estudantes 6: Não, pois sou ateu/Não, pois sou ateu.
Estudante 14:eu acredito que a bíblia é um livro sagrado pois ela contém as histórias e os ensinamentos de entidades divinas e de grandes povos. E sobre a bíblia ser o único livro sagrado, apesar de respeitar e procurar saber sobre as crenças de outros povos, eu acredito que a bíblia é o único livro sagrado pois ela carrega os ensinamentos do meu Deus, povos que compartilhavam a minha religião.

Estudante 15:Creio que a bíblia seja um livro sagrado, pois mesmo se você tirar as questões religiosas ainda existem diversos versículos que te guiam a ter uma conduta melhor que sua própria natureza, creio também que a bíblia nos ensina a ter uma vida melhor em vários sentidos englobando até mesmo o setor financeiro de sua vida pois existem versículos focados em prosperidade e, não podemos esquecer que a bíblia de registra de uma boa maneira a história de um povo o que a torna um livro muito importante para a humanidade. Não sei se considero somente a bíblia um livro sagrado pois existem livros com as mesmas funções que vejo na bíblia.
\end{abstract}

Para a maior parte dos estudantes, o caráter sagrado da bíblia não implica em perfeição ou ausência de erros. 55,3\% afirmaram que a bíblia possui algum erro. $25 \%$ acreditam que não e outros $18,8 \%$ acham que talvez.

Quadro 02 - o perfil religioso dos estudantes.

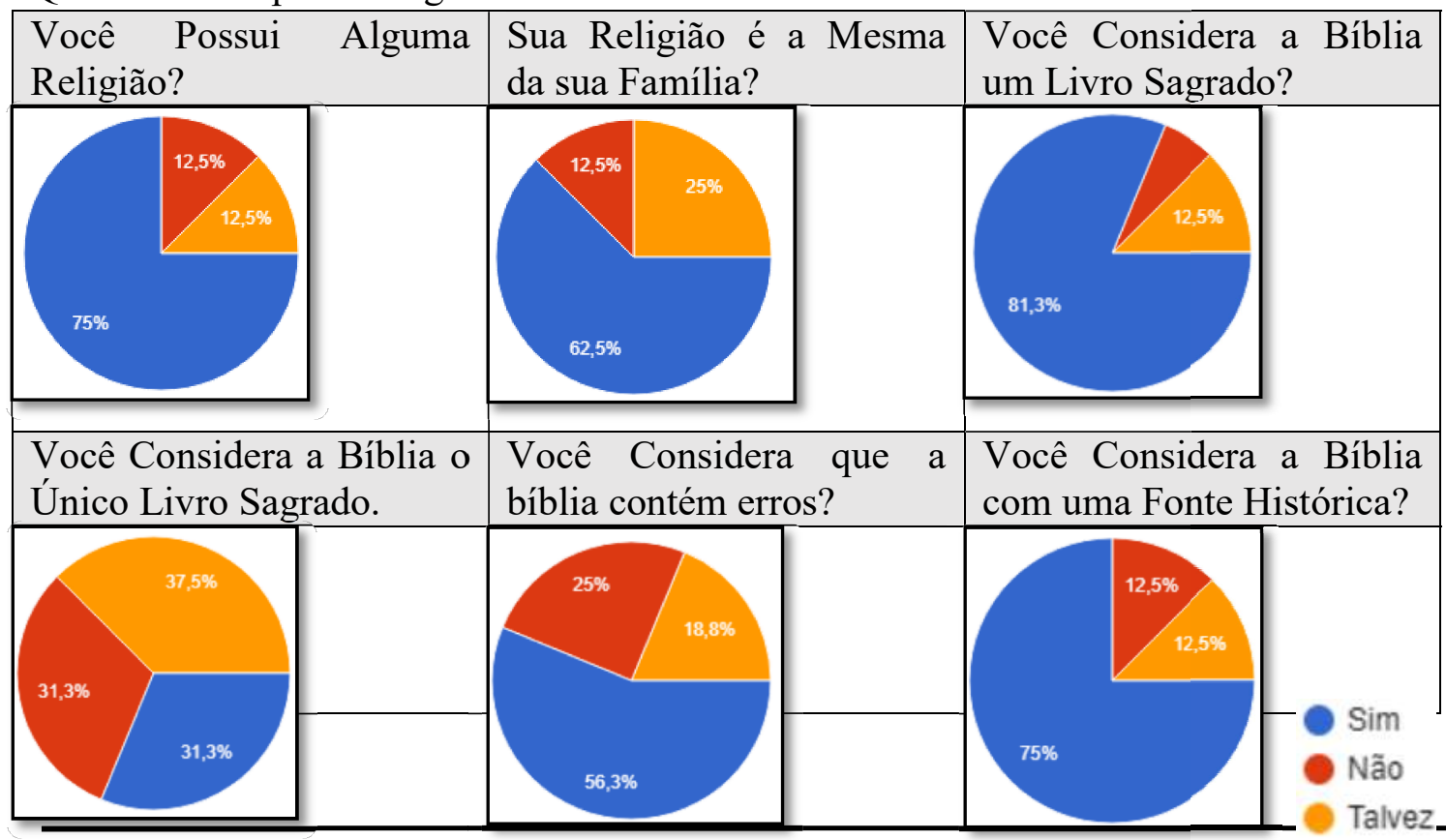




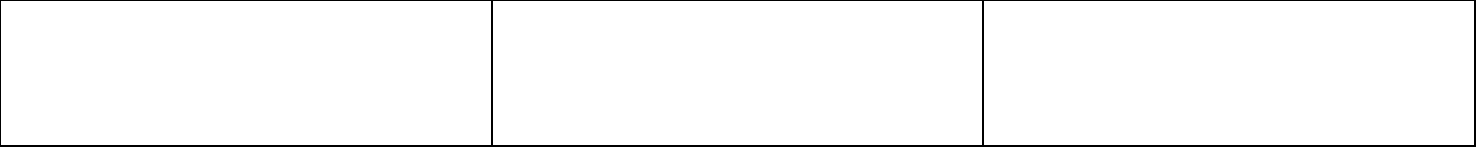

De acordo com o quadro $03,12,5 \%$ dos estudantes não consideram a bíblia uma fonte histórica. As justificativas foram pautadas nos argumentos de que houve alterações na sua escrita com passar do tempo e que os eventos nela registrados não são comprovados. Os 12,5\% que acreditam que a bíblia, talvez, seja uma fonte histórica argumentaram que o seu caráter histórico (capacidade de demonstrar os modos de vida do tempo em que foi escrita) pode ser comprometido pelo olhar religioso.Entre os $75 \%$ que consideram a bíblia uma fonte histórica, 7 estudantes justificaram afirmando que ela registra os eventos, fatos e costumes do passado. Outros dois tomaram como fundamento o fato dela relatar eventos "antigos". Um estudante justificou que a bíblia é uma fonte histórica a partir de um argumento religioso “[...]história da passagem de 'Jesus no nosso mundo[...]”. Para outro discente, a bíblia é uma fonte histórica, visto querelata eventos que, comprovadamente, aconteceram. Ou seja, dentre os que afirmam e negam o caráter histórico da bíblia, é comum a ideia de que a história está associada à verdade ou à comprovação dos fatos.

No trato do conteúdo da história do povo hebreu, solicitamos que os estudantes citassem e escrevessem um resumo sobre algum evento que eles recordassem. 11 dos 16 estudantes escreveram sobre a escravidão no Egito, o Êxodo ou "recebimento dos dez mandamentos". Deste grupo, apenas um estudante não citou o nome de Moisés nem utilizou elementos religiosos para desenvolver a narrativa. Ele escreveu:(Estudante 6) "Os hebreus depois da grande seca na Palestina, foram para o Egito em busca de comida, mas ao chegar no Egito os hebreus foram escravizados". A estrutura de tal narrativa, porém, está alinhada à versão bíblica da história dos hebreus.

Em todos os outros 10 casos deste mesmo grupo, assim como no caso do estudante que escreveu sobre José (filho de Jacó), as narrativas dos acontecimentos históricos foram permeadas de elementos religiosos:

(Estudante 1) "José, filho de Jacó era um garoto que seguia as leis de Deus e obedecia seu pai com tudo q ele mandava"; (Estudante 2) "Moisés abriu misteriosamente o mar vermelho"; (Estudante3) "Foram feitos 10 mandamentos para serem como regras e serem cumpridos. foi enviado por Deus a Moisés"; (Estudante 4) "O êxodo ocorreu com a fuga dos israelitas sobre o mar vermelho com Moises abrindo o mar com um cajado"; (Estudante 7)“'Os hebreus fogem de Canaã, até que chegam na mergem do mar vermelho,e os egípicios os perseguem, eles acham que ali seria o seu fim, até que Deus ordena Moisés a estender o seu cajado sobre o mar, ele se abre abrindo passagem para os hebreus, os egípicios os perseguem dentro do mar e são engolidos por ele em certo ponto".(Estudante 8)“Os Hebreus eram escravizados no Egito por muito tempo até que conseguiram fugir e foram perseguidos pelo exército.Deus com sua misericórdia falou para Moisés 
confiar Nele pois Ele abriria o Mar Vermelho para o povo poder passar em segurança.Enquanto todos passavam em segurança os soldados continuavam os perseguindo, então quando todos chegaram do outro lado do Mar Deus afogou todos os soldados do exército".(Estudante 9)"Moisés recebeu uma mensagem de Deus para que ele e seu povo fosse a terra prometida para que assim conseguissem se libertar da escravidão, no longo caminho eles foram perseguidos e ao chegar à margem do mar vermelho, Moisés pediu a Deus que ele abrisse o mar vermelho para que eles pudessem passar. Quando os hebreus terminaram de passar o mar fechou-se matando os perseguidores".(Estudante 11)“Moisés abre o Mar Vermelho com o cajado".

Outro estudante escreveubuscou desenvolver uma explicação sobre outro momento histórico sem utilizar elementos religiosos. O (Estudante 15)afirmou que:

O território Hebreu pertence ao império Persa e tem sua cultura preservada. Algum tempo depois Alexandre o Grande começa a conquistar os terras do império Persa assim anexando o território Hebreu, sua cultura continua sendo preservada e Alexandre tem várias interações com este povo.

Quadro 3 - escrita dos estudantes sobre os eventos históricos do povo hebreu.

\begin{tabular}{|l|l|l|}
\hline EVENTO & $\begin{array}{l}\text { NÚMERO DE } \\
\text { RESPOSTAS }\end{array}$ & $\begin{array}{l}\text { FUNDAMENTAÇÃO } \\
\text { RELIGIOSA }\end{array}$ \\
\hline JOSÉ DO EGITO & 1 & SIM \\
\hline MOISÉS & 10 & SIM \\
\hline ESCRAVIDÃO NO EGITO & 1 & NÃO \\
\hline DOMÍNO PERSA & 1 & NÃO \\
\hline $\begin{array}{l}\text { NÃO DESENVOLVERAM } \\
\text { UMA RESPOSTA }\end{array}$ & 3 & SEM RESPOSTA \\
\hline
\end{tabular}

Ao questionarmos os locais de aprendizagem sobre o evento que os estudantes mais recordam, verificamos um peso significativo da "bíblia", "igreja” e "família". Em seguida, temos cinco estudantes que alegaram ter apreendido muito sobre os hebreus a partir das telenovelas.

Imagem 1 - locais de aprendizagem sobre a história dos hebreus.

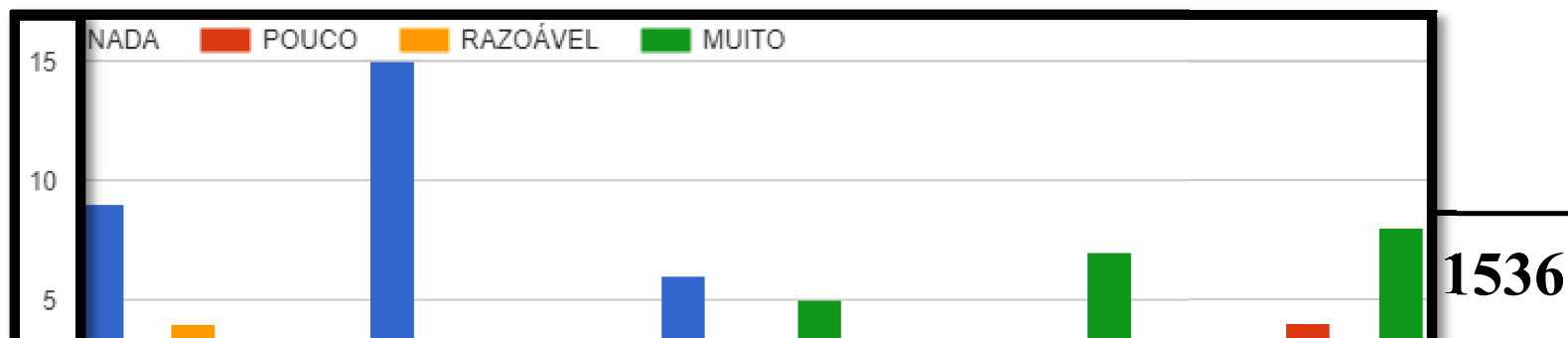


Ainda sobre os locais de aprendizagem, investigamos a repercussão do filme ou da telenovela sobre os 10 Mandamentos produzidos pela Emissora Record. Dentre os entrevistados, todos os estudantes já tiveram algum contato com a série, mesmo que somente de ouvir falar. Isso pode nos a ajudar a compreender o fato de que o evento mais conhecido entre os estudantes está relacionado ao Êxodo.

Imagem 2 - o que os estudantes sabem sobre o filme/série os 10 mandamentos.
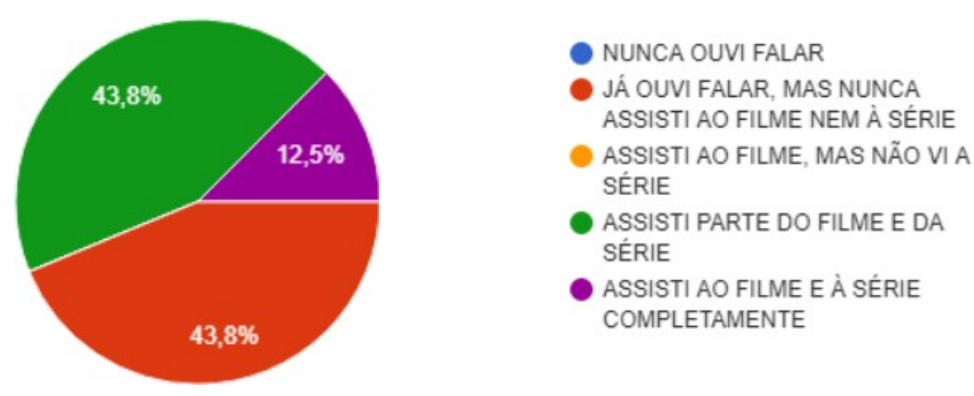

Em seguida, investigamos as relações que os estudantes estabelecem entre a história dos hebreus e dos povos outros pois com os quais dialogaram. Solicitamos que eles escolhessem e aportassem sobre um desses povos, como os egípcios, os cananeus, os fenícios, os assírios, os babilônicos, os persas, os macedônicos, os romanos ou outros.

Dos 16 participantes da pesquisa, 14 responderam escreveram uma breve explicação sobre a história de um dos povos que interagiram com os hebreus. A maior parte (6 estudantes) escreveram sobre os romanos. Nesta parte do questionário, as respostas foram 
mais bem elaboradas. Muitos estudantes conseguiram explorar aspectos sociais, econômicos, políticos ou culturais dos povos antigos escolhidos.

Quadro 4 - escrita dos estudantes sobre os povos que dialogaram com os hebreus.

\begin{tabular}{|l|l|}
\hline EVENTO & NÚMERO DE RESPOSTAS \\
\hline ROMANOS & 6 \\
\hline MACEDÔNICOS & 3 \\
\hline EGÍPCIOS & 2 \\
\hline FENÍCIOS & 2 \\
\hline BABILÔNICOS & 1 \\
\hline
\end{tabular}

Enquanto a maior parte do conteúdo sobre os hebreus foi apreendida nas igrejas, famílias e telenovelas,os estudantes demonstram ter aprendido mais sobre os povos vizinhos a partir do conhecimento promovido pela escola.

Imagem 3-locais de apendizagem sobre os povos que dialogaram com os hebreus.
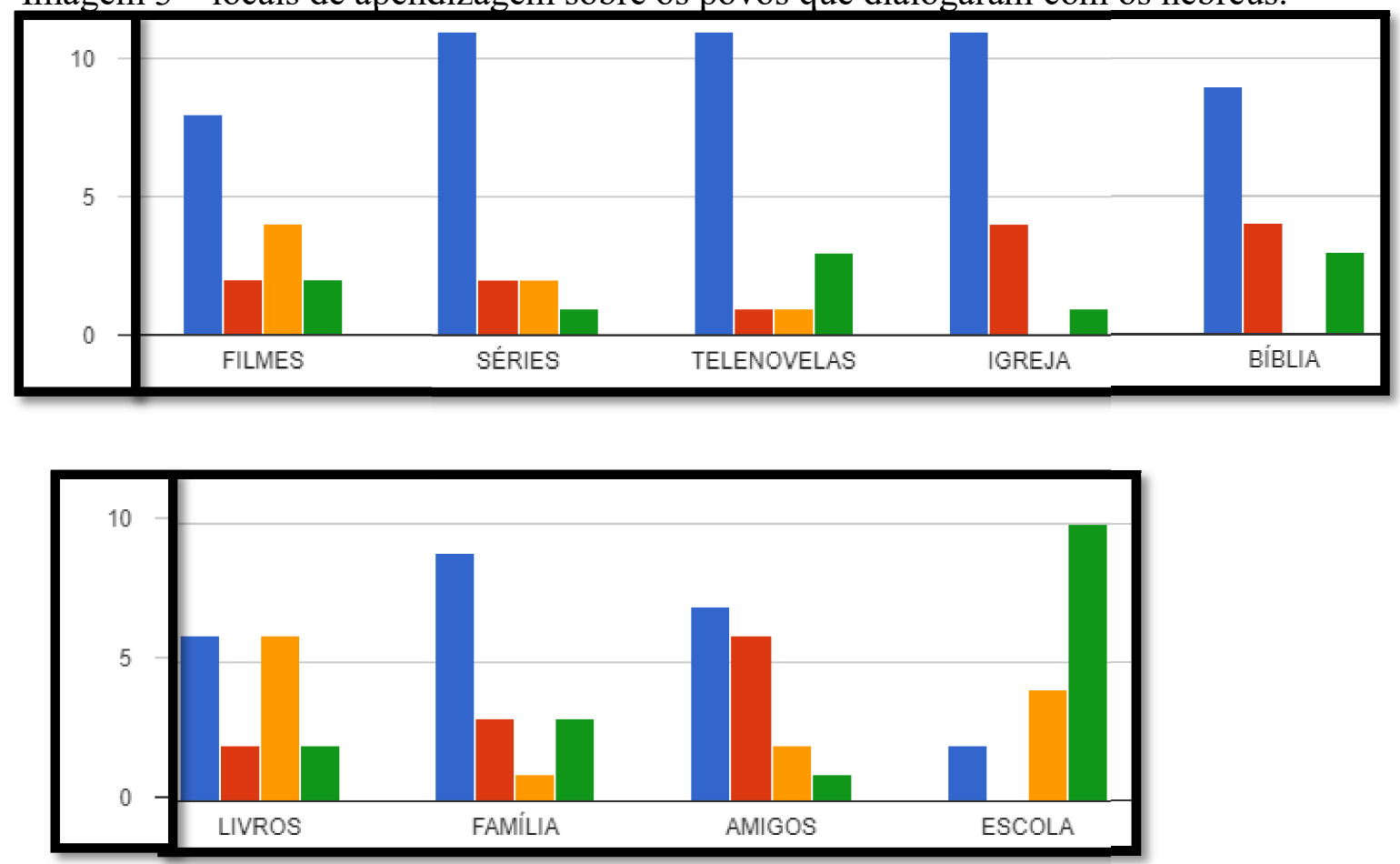

Ao escreverem sobre os povos que dialogaram com os hebreus, a maior parte dos estudantes não tomaram como fundamento perspectivas religiosas, ou seja, não inseriram na narrativa eventos ou seres sobrenaturais. Das quatorze respostas, apenas utilizou uma abordagem religiosa:

Estudante 1: Babilônia: Um reino vizinho a Jerusalém o povo de Deus. Um certo dia, os babilônicos (povo da antiga babilônia) conquistaram a terra dos hebreus e levaram alguns dele como escravos tipo os senhores de terras o ricos e os de poder. A babilônia era um reino politeísta (que acreditavam em vários deuses) 
esse reino era comandado pelo rei Nabuccodonosor que era rei de um reino prospero. Assim continuou por vários anos até que ele morreu.

Prosseguimos a nossa análise investigando como os estudantes encaram a bíblia, sobretudo a Lei Mosaica, na relação comoutras literaturas legais da antiguidade oriental. Solicitamos uma comparação entre o Código de Hamurabi e a Lei de Moisés. Verificamos que os estudantes encontram dificuldade em classificar os textos bíblicos de acordo com as suas características literárias.O texto de Levítico 20: 10, por exemplo, foi tratado como profecia por $75 \%$ dos participantes, quando, na verdade, é uma literatura legal. 2 Samuel, por sua vez, é uma literatura histórica. $25 \%$ dos estudantes classificaram como carta e outros $6,2 \%$ como profecia.

Quadro5 - variação literária bíblica segundo os estudantes.

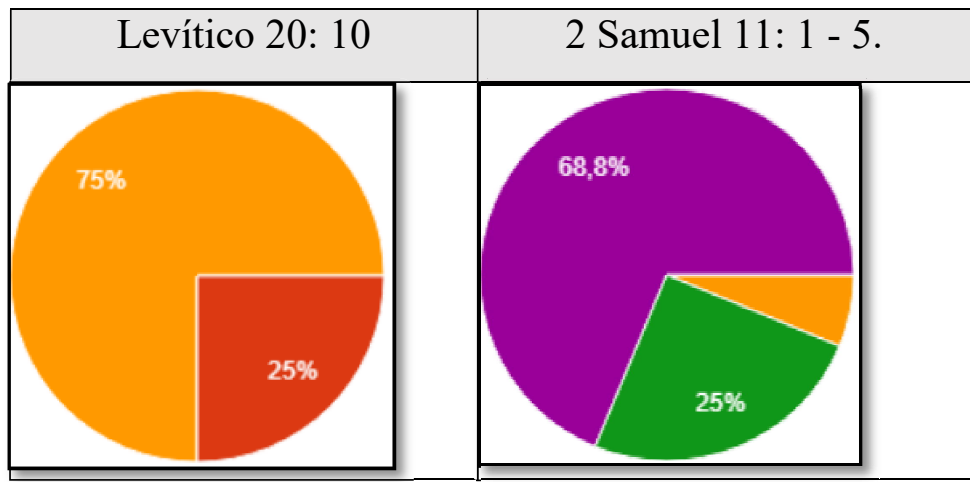

POESIA

CÓDIGO DE LEIS

PROFECIA

CARTA

HISTÓRICO

NOTÍ́CIA

Todos os estudantes conseguiram identificar, pela leitura da descrição das fontes, que a escrita do Código de Hamurabi aconteceu antes dos 10 Mandamentos.9 estudantes(56,3\%) responderam que os 10 mandamentos e o Código de Hamurabi compartilham do princípio do Talião. No entanto, 5 estudantes(31,3\%) afirmaram que "não" e outros 2 (12,5\%) afirmaram que "não".

Sobre a aplicação do princípio resumido pela frase "olho por olho, dente por dente", objetivamos verificar em que medida os estudantes encaram os usos da lei mosaica nos dia atuais e se as argumentações religiosas são utilizadas na defesa da execução de penas capitais. Das 13 justificativas desenvolvidas, apenas uma foi estruturada em argumentação religiosa. $\mathrm{O}$ Estudante 1 respondeu que o princípio do Talião não deve ser utilizado atualmente "porque na bíblia diz para que nós devemos amarmos nossos próximos".

Quadro 6 - aplicações do princípio do talião pelos estudantes.

Você concorda com a aplicação

\begin{tabular}{|lllll|l|}
\hline Tipos justificativa & para & a & não & Número de \\
\hline
\end{tabular}




\begin{tabular}{|l|}
\hline $\begin{array}{l}\text { do princípio do Talião na } \\
\text { atualidade? }\end{array}$ \\
\hline SIM \\
\hline 1 \\
\hline NÃO \\
\hline 15 \\
\hline
\end{tabular}

\begin{tabular}{|l|l|}
\hline $\begin{array}{l}\text { aplicação do princípio do Talião na } \\
\text { atualidade. }\end{array}$ & respostas. \\
\hline Argumentos Religiosos & 1 \\
\hline Princípios Morais & 4 \\
\hline Antigo/Moderno - Atual - Civilizado. & 3 \\
\hline Pragmatismo & 5 \\
\hline
\end{tabular}

O único estudante favorável à aplicação do princípio da talião não desenvolveu uma justificativa. Quatro estudantes apelaram para princípios morais "certo" e "errado" sem reivindicar na argumentação nenhuma fundamentação religiosa, como o caso do Estudante 6, que respondeu: "Porque é errado você fazer aos outros o que não quer que seja feito a você”. Outros 5 estudantes utilizaram argumentações de ordem prática, como o Estudante 9, que respondeu: "A justiça tem maneiras de combater o crime, mesmo que aparentemente não seja eficiente, para mim o método de justiça atual é tão eficiente ou mais do que o método de olho por olho, dente por dente". 3 estudantes apresentaram uma visão assimétrica entre atualidade (civilizado) e antiguidade, sugerindo que o mundo leis rígidas são desnecessárias em um mundo civilizado, como o Estudante 14, que respondeu: "Não pois na sociedade atual temos a capacidade de prover um sistema mais sofisticado".

\section{Considerações Finais}

Apesar de, entre os entrevistados, muitos estudantes encontrarem dificuldade para mobilizar conceitos da história na construção de uma narrativa sobre os hebreus, percebemos um elevado nível de sofisticação no que se refere a operação de conceitos epistemológicos fundamentais no trato das fontes históricas antigas, incluindo os textos bíblicos. Além disso, eles demonstraram um conhecimento razoável sobre os povos que dialogaram com os hebreus. Verificamos que as igrejas e a televisão ocuparam um peso significativo na construção da cognição histórica dos estudantes. Contrariando as nossas hipóteses iniciais, a maior parte dos estudantes não reconhece a validade da continuação do princípio do "olho por olho, dente por dente" nem apelaram para uma argumentação religiosa. Isso pode sinalizar a construção de uma consciência crítica ou genética.

Não sabemos ao certo o impacto que a Base Nacional Comum Curricular terá sobre a produção dos materiais didáticos previstos para as próximas edições do PNLD, e de que maneira o novo documento reduzirá o conteúdo de Antiguidade Oriental de modo a excluir tanto a história dos Fenícios e Hebreus, localizados no oriente próximo, como a História da China, no extremo oriente, todos presentes na maioria dos materiais didáticos. 
Também,desconhecemos quais serão os efeitos do enxugamento da História Oriental e da ausência do tema transversal "orientação sexual" na formação da cognição e da consciência histórica da população brasileira. Delegaremos tais instruções às Igrejas e Emissoras de Televisão que dominam a distribuição de versões religiosas e moralizantes da História dos Hebreus e dos povos vizinhos?

A Universidade e a Escola Pública, além de avançar no diálogo com a comunidade e democratizar cada vez mais os seus espaços, precisa amadurecer reflexões acadêmicas sobre as temáticas que atravessam a orientação existencial e religiosa do homem comum, oferecendo-o ferramentas que o auxiliem a enxergar possibilidades de interpretação e de ação além das adquiridas pela tradição familiar e religiosa, ou mesmo pelos meios de comunicação de massa.

\section{Referências}

ABUD, K.M. O livro didático e a popularização do saber histórico. Em SILVA, M. A. (org), Repensando História. Rio de Janeiro: Ed. Marco Zero, 1984.

ALMEIDA, LudimillaSavry dos Santos. Saberes em movimento: futuros professores de História e seus sentidos de Antiguidade. Tese de Doutorado - UFJF, 2015.

ALVES, Ronaldo Cardoso. Aprender história com sentido para a vida: consciência histórica em estudantes brasileiros e portugueses. Tese de Doutorado USP.

ALVES, R. O que é Religião? 6a ed. São Paulo: Ed. Loyola, 2005.

ALVES-MAZZOTTI, A; GEWANDSZNAJDER, F. O Método nas ciências naturais e sociais: pesquisas quantitativas e qualitativas. São Paulo: Pioneira, 2004.

ARTER, Robert / KERMODE, Frank. Guia Literário da Bíblia. São Paulo: UNESP, 1997. BETTENCOURT, Circe Maria Fernandes. Ensino de História: Fundamentos e métodos.2a ed. São Paulo: Cortez, 2008.

BRASIL. Secretaria de Educação Fundamental. Parâmetros curriculares nacionais: terceiro e quarto ciclos do ensino fundamental: introdução aos parâmetros curriculares nacionais / Secretaria de Educação Fundamental. - Brasília : MEC/SEF, 1998. P. 65 - 68.

DA SILVA, A. A História de Israel na Pesquisa Atual, In: FARIA, J. F. (org.) História de Israel e as pesquisas mais recentes. 2. ed. Petrópolis: Vozes, 2003.

DONNER, Herbert. História de Israel e dos povos vizinhos V.1\&V.2. 2. ed. Tradução de C. Molz e H. Trein. São Leopoldo: Sinodal, 1997.

FEINBERG, John S. Continuidade e descontinuidade: perspectivas sobre o relacionamento entre o antigo e o novo testamento: Ensaios em homenagem ao S. Lins e Johnson Jr. São Paulo: Hagnos, 2013.

GARELLI, P. \& NIKIPROWETZKY, V. O Oriente Próximo Asiático: impérios Mesopotâmicos - Israel. São Paulo: Pioneira, Edusp. 1982.

JÚNIOR, Alfredo Boulos. História, Sociedade e Cidadania. São Paulo: FTD, 2016. 
KING, Noel, Hermeneutics, reception aesthetics , and film interpretation, In HILL, John. ; Gibson, Pamela Church., eds. The Oxford guide to film studies, Oxford, Oxford University Press, 1998.

LEE, P.(2001): "Progressão da compreensão dos alunos em história", Jornadas Internacionais de Educação Histórica, Centro de Estudos em Educação e Psicologia: Braga, p.13-17

LESSARD-HÉBERT, M; GOYETTE, G. e BOUTIN, G. Investigação Qualitativa: fundamentos e práticas. Tradução de: REIS, M, J. $2^{\mathrm{a}}$ ed. Lisboa: Instituto Piaget, 2005.

LIVERANI, Mario. Para Além da Bíblia: História Antiga de Israel. São Paulo: Editora Paulos, 2008.

MARIANO, Ricardo. Expansão pentecostal no Brasil: o caso da Igreja Universal. ESTUDOS AVANÇADOS 18 (52). São Paulo: USP, 2004.

NECHI, Lucas Pydd. Educação histórica e religião: aproximações a partir de um estudo da consciência histórica de jovens alunos. Dissertação (Mestrado em Educação) - Setor de Educação, Universidade Federal do Paraná - Curitiba, 2011.

MIRANDA, S. R..Sob o signo da Memória: cultura escolar, saberes docentes, História ensinada. 1. ed. São Paulo: UNESP, 2008. .

MIRANDA, S. R.; DE ALMEIRA, Fabiana Rodrigues. Memória e História em livros didáticos de História: o PNLD em perspectiva. Educar em Revista, Curitiba, Brasil, n. 46, p. 259-283, out./dez. 2012. Editora UFPR. Disponível em: < http://www.scielo.br/pdf/er/n46/n46a18.pdf $>$.

NAPOLITANO, Marcos. Como usar a televisão em sala de aula. São Paulo: Contexto, 2008.

PEREIRA, J. S. ; MIRANDA, S. R. . Laicização e Intolerância Religiosa: desafios para a História ensinada. Educação e Realidade, v. 42, p. 1-22, 2017.

RICOEUR, Paul. Hermenêutica Bíblica. São Paulo: Edições Loyola, 2006. 17

RÜSEN, J. El desarrollo de La competência narrativa em el aprendizaje histórico. Una hipótesis ontogenética relativa a consciência moral. Trad. Silvia Finocchio. Propuesta Educativa, Argentina, n.7, out. 1992.

RÜSEN, J. História Viva - Teoria da História III: formas e funções do conhecimento histórico. Brasília: Ed. UNB, 2007.

WELLHAUSEN, Julios. ProlegonemaZurGeschichteIsraels. Universidade de Troronto. < https://archive.org/details/prolegomenazurge00well >. 


\title{
Estado "multiconfessional": desafios à isonomia entre as identidades religiosas Multiconfessional State: challenges to the isonomy between religious identities
}

\author{
Robson César Durão ${ }^{13}$ \\ sgt_cesar2@hotmail.com \\ Laíne Tavares Miranda ${ }^{14}$ \\ lainemiranda@tjrj.jus.br
}

\begin{abstract}
Resumo: A principal questão do presente estudo é analisar se o ensino religioso confessional nas escolas públicas fere a isonomia entre as diferentes identidades religiosas. Para tanto, foi empregada como metodologia a pesquisa qualitativa jurisprudencial e a pesquisa bibliográfica em livros e artigos de periódicos, tendo como referencial teórico as ideias comunitaristas de Charles Taylor. O trabalho está dividido em três partes, a primeira seção do texto apresenta a decisão da $\mathrm{ADI} \mathrm{n}^{\circ} 4439$. Na segunda parte, discute-se o postulado do direito fundamental à liberdade. Por fim, são apontadas as dificuldades concretas que a decisão do STF impõe à liberdade religiosa e à igualdade entre asreligiões. Os resultados encontrados com estudo demonstram que a decisão fere a isonomia entre os diferentes credos. Conclui-se que o ensino religioso não deve estar vinculado a qualquer religião específica, razão pela qual a disciplina Religião deve serensinada sob uma perspectiva laica.
\end{abstract}

Palavras-Chave: ensino confessional; liberdade religiosa; isonomia; laicidade; comunitarismo.

\begin{abstract}
The main issue of the present study is to investigate whether confessional religious teaching in public schools hurts the equality between different religious identities. In order to do so, the qualitative research of jurisprudence and the bibliographical research in books and periodical articles were used as methodology, having as theoretical reference the communitarian ideas of Charles Taylor. The paper is divided into three parts, the first section of the text presents the ADI decision 4439. In the second part, the postulate of the fundamental right to freedom is discussed. Finally, the concrete difficulties that the STF decision imposes on religious freedom and on equality between religions are pointed out. The results found with study demonstrate that the decision hurts the isonomy between the different creeds. It is concluded that religious education should not be linked to any specific religion, which is why Religion should be taught from a secular perspective. Keywords: confessional teaching; religious freedom; isonomy; secularism; communitarianism.
\end{abstract}

\section{Introdução}

Com amparo no princípio da isonomia, é dever do Estado assegurar e promover indistintamente todas as identidades religiosas no espaço público, possibilitando amplo reconhecimento aos diferentes credos que existem na sociedade. Por isso, o presente artigo tem

\footnotetext{
${ }^{13}$ Mestre em Direito pela Universidade Católica de Petrópolis, Petrópolis, Rio de Janeiro, Brasil; Pós-Graduado em Direito Público pelo Damásio Educacional; Bacharel em Direito pela Universidade Estácio de Sá.

${ }^{14}$ Mestranda em Direito pela Universidade Católica de Petrópolis, Petrópolis, Rio de Janeiro, Brasil; PósGraduada em Direito Processual pela Universidade Federal de Juiz de Fora, Minas Gerais; Pós-Graduada em Direito: Grandes Transformações pela Universidade do Sul de Santa Catarina; Bacharel em Direito pela Universidade Federal de Juiz de Fora, Minas Gerais. Instituição vinculada: Universidade Católica de Petrópolis.
} 
como questão principal apreciar se o ensino religioso confessional nas escolas públicas viola a isonomia, considerando a dificuldade prática de se assegurar a contratação de professores de todas as religiões.

O texto tem o objetivo de analisar, sob a perspectiva do comunitarismo, a decisão proferida na ADI $n^{\circ} 4.439$ e os argumentos levantados pelos ministros do STF que confirmaram a constitucionalidade do ensino confessional nas escolas públicas. Na ação, a PGR pedia a interpretação conforme a Constituição Federal ao dispositivo da Lei de Diretrizes e Bases da Educação para assentar que o ensino religioso nas escolas públicas não pode ser vinculado a religião específica e que é proibida a admissão de professores na qualidade de representantes das confissões religiosas. A Procuradoria Geral da República sustentouque a disciplina a ser lecionada deveria ser laica, com matrícula facultativa, e deveria ser voltada para a história e a doutrina das distintas religiões.

\section{Isonomia e o Ensino Confessional}

O pressuposto da liberdade religiosa é a laicidade, modelo no qual todas as religiões têm o mesmo valor. Isso porque é evidente a existência de uma intrínseca relação entre o direito à liberdade e a isonomia, pois não há liberdade religiosa sem que todas as religiões sejam tratadas como iguais - fato que só é possível no ambiente político laico. Rui Barbosa defendia a liberdade religiosa com fundamento na autodeterminação, por considerá-la do ponto de vista da liberdade individual do homem. Segundo esse renomado jurista (1877a, p. 419), de todas as liberdades sociais, nenhuma é tão congenial ao homem, e tão nobre, e tão frutificativa, e tão civilizadora, e tão pacífica, e tão filha do evangelho, como a liberdade religiosa, que representa uma condição substancial para os distintos direitos a liberdades civis e políticas.

A partir da valorização da liberdade religiosa, Rui Barbosa (1898, p. 92) justifica a separação entre o Estado e a Igreja, propondo uma forma de Estado laico que elimine o padroado chamado por ele de anomalias anacrônicas. No Brasil, o Decreto 119-A de 7 de janeiro 1890 interrompe a hegemonia do regime do padroado e seculariza o Estado brasileiro, tendo claras influências ideológicas de Rui Barbosa.

Todavia, o modelo de Estado secular apenas se concretizou com a primeira Constituição Republicana do Brasil de 1891, como explica Daniel Sarmento (2007, p.3), de modo que o princípio da laicidade foi expressamente consagrado pelo art. 19, inciso I, do Texto Magno, segundo o qual é vedado a todas as entidades da federação "estabelecer cultos 
religiosos ou subvencioná-los, embaraçar-lhes o funcionamento ou manter com eles ou seus representantes relações de dependência ou aliança, ressalvada, na forma da lei, a colaboração de interesse público".

Já no século XX, com o advento da constituição de 1934, se manteve o secularismo do Estado e a liberdade religiosa. A previsão naquele diploma, em seu art. 17, incisos II e III, era de que, dentre os direitos promulgados pela Assembleia Constituinte, se encontravam a inviolabilidade da liberdade de consciência, o livre exercício dos cultos religiosos e a liberdade religiosa como direitos individuais. $\mathrm{O}$ art. 113, itens 4, 5, 6 e 7, dentre outros de natureza igual, trazia o rol de direitos individuais, que permaneceram análogos àqueles previstos na Carta de 1937. As Constituições brasileiras de 1946, 1967 e a Emenda Constitucional de 1969, asseguram os direitos individuais já postos pelas Constituições de 1981, 1934 e 1937 como a liberdade religiosa, o respeito ao culto no espaço público das distintas confissões religiosas e o respeito à liberdade de consciência.

Nota-se, pois, que a laicidade do Estado foi e ainda é fruto de um consenso democrático, encontrando-se intrinsecamente relacionada aos princípios fundamentais da liberdade religiosa e da igualdade. No mundo contemporâneo globalizado e multicultural, tais princípios, por vezes, são invocados para dirimirem demandas religiosas.

Neste diapasão, a Constituição cidadã de 1988, da República Federativa do Brasil, é questionada a dar respostas plausíveis às demandas do Estado sobre o alcance dos princípios fundamentais como o da laicidade do Estado, da liberdade religiosa e da igualdade, enfatizando que a igualdade sempre se encontra em um dos polos das argumentações jurídicas e filosóficas sobre os direitos e deveres do Estado na concretização e promoção dos princípios mencionados.

Assim, o Supremo Tribunal Federal foi provocado a se manifestar em Ação Direta de Inconstitucionalidade (ADI) 4439, proposta pela Procuradoria-Geral da República (PGR),a respeito da constitucionalidade do ensino religioso nas escolas da rede pública.Em sessão plenária realizada no dia 27 de setembro de 2017, por maioria dos votos, os ministros concluíram que o ensino religioso nas escolas públicas brasileiras pode ter natureza confessional, ou seja, pode ser vinculado às diversas religiões.

Na ação, a PGR pedia a interpretação conforme a Constituição Federal ao dispositivo da Lei de Diretrizes e Bases da Educação - LDB (caput e parágrafos $1^{\circ}$ e $2^{\circ}$, do artigo 33, da Lei 9.394/1996) e ao artigo $11, \S 1^{\circ}$ do acordo firmado entre o Brasil e a Santa Sé (promulgado por meio do Decreto 7.107/2010), para assentar que o ensino religioso nas escolas públicas não pode ser vinculado a religião específica e que não seadmite a contratação de professores 
na qualidade de representantes das confissões religiosas. Sustentava-se que tal disciplina, cuja matrícula é facultativa, deve ser voltada para a história e a doutrina das várias religiões, ensinadas sob uma perspectiva laica.

A ministra Cármen Lúcia, seguiu a divergência apresentada inicialmente pelo ministro Alexandre de Moraes, no sentido de julgar o pedido formulado na ação improcedente a fim de que o ensino religioso nas escolas públicas brasileiras tenha natureza confessional. Ressalta CármenLúcia (2017c. p. 9)que: "A laicidade do Estado brasileiro não impediu o reconhecimento de que a liberdade religiosa impôs deveres ao Estado, um dos quais a oferta de ensino religioso com a facultatividade de opção por ele". Destacou que todos estão de acordo com a condição do Estado laico do Brasil, a tolerância religiosa, bem como a importância fundamental às liberdades de crença, expressão e manifestação de ideias.

Em seu voto, o ministro Alexandre de Moraesressaltou que o campo de discussão da demanda em análise alcança a liberdade de expressão de pensamento sob a luz da tolerância e diversidade de opiniões. Enfatiza que a presente ação pretende limitar o legítimo direito subjetivo constitucional do aluno que já possui religião ou de seu pai/responsável de matricular-se no ensino religioso de sua própria confissão, impondo forte censura prévia às opiniões religiosas diversas, por pleitear um conteúdo neutro e meramente descritivo de religiões, em uma impensável "doutrina religiosa oficial”, criada artificialmente pelo Poder Público, mesmo que em disciplina de matrícula facultativa.

Entende o ministro Moraes ainda que o Poder Público, observado o binômio Laicidade do Estado (CF, art. 19, I)/Consagração da Liberdade religiosa (CF, art. 5º, VI), deverá atuar na regulamentação integral do cumprimento do preceito constitucional previsto no artigo 210, $\S 1^{\circ}$, autorizando na rede pública, em igualdade de condições (CF, art. $5^{\circ}$, caput), o oferecimento de ensino confessional das diversas crenças, mediante requisitos formais previamente fixados pelo Ministério da Educação.Dessa maneira, expõe que será permitido aos alunos, que expressa e voluntariamente se matricularem, o pleno exercício de seu direito subjetivo ao ensino religioso como disciplina dos horários normais das escolas públicas de ensino fundamental, ministrada de acordo com os princípios de sua confissão religiosa, por integrantes de cada confissão, devidamente credenciados a partir de chamamento público e, preferencialmente, sem qualquer ônus para o Poder Público.

Outro ponto importante destacado pelo ministro Alexandre de Morais perpassa pela ideia de que a definição do núcleo imprescindível do ensino religioso como sendo os dogmas de fé demonstra que não há possibilidade de neutralidade ao se ministrar essa disciplina. Isso porque cada uma das diversas confissões religiosa possui seus próprios dogmas estruturantes, 
postulados, métodos e conclusões que o diferenciam de todos os demais ramos do saber jurídico e deverá ser oferecida segundo a confissão religiosa manifestada voluntariamente pelos alunos, sem qualquer interferência estatal. Neste sentido, o Estado não deve impor determinada crença religiosa nem estabelecer fíctício conteúdo misturando diversas crenças religiosas, em desrespeito à singularidade de cada qual, ou confundindo o ensino religioso com o estudo de história, filosofia ou ciência das religiões.

Moraes afirma não haver dúvidas sobre a possibilidade de diversas crenças e religiões poderem ser estudadas de maneira meramente descritiva ou sob o ponto de vista neutro, histórico, filosófico, sociológico, antropológico, político, sociocultural e, mesmo, do ponto de vista jurídico; assim como esses diversos ramos da ciência humana estudam outros importantes temas; mas jamais se confundirão com o conteúdo específico e singular do "estudo religioso".Alexandre de Moraes destaca, assim, que não se pode confundir Estado Confessional com um Estado laico que garanta o ensino religioso ministrado de acordo com os princípios da confissão religiosa do aluno, independentemente de sua crença.

Para o ministro, um Estado não consagra verdadeiramente a liberdade religiosa sem absoluto respeito aos seus dogmas, suas crenças, liturgias e cultos. Em conclusão, o ministro Moraes esclarece que quem pretender ter um ensino religioso cristão, obrigatoriamente, precisará ter acesso à Bíblia, cuja interpretação católica, luterana, calvinista, anglicana, pentecostal não é absolutamente idêntica; caso seja espírita, também precisará extrair ensinamento do Livro dos Espíritos e ao Evangelho Segundo o Espiritismo, ambos de Allan Kardec. Por outro lado, esses textos serão substituídos pelo estudo judaico do Torá; ou pela análise do Corão no islamismo. Se for adepto de uma das religiões de matriz africana, precisará estudar o culto aos orixás, o "jogo de búzios" ou "ifá", caso adote o Candomblé; ou o estudo dos rituais dos espíritos de Caboclos, Pretos-Velhos, Baianos, Exus, Pombos Gira, caso adote a Umbanda. Ressalta novamente que em todas essas hipóteses, e no ensino das demais confissões religiosas, a neutralidade não existe, já que os ensinamentos e o aprendizado se baseiam, fundamentalmente, nos dogmas de fé, que não podem ser substituídos por narrativas gerais, meramente descritivas, neutras e contraditórias.

O ministro Ricardo Lewandowski, em sua fundamentação, menciona as orientações extraídas das "Diretrizes de Toledo", com a sistematização das boas práticas concernentes ao ensino religioso nas escolas públicas à luz de princípios internacionais de direitos humanos, permitindo a dedução de regras concretas relativas ao ensino religioso, em tal contexto, de forma respeitosa e inclusiva.Segundo essas recomendações e conforme elucida Ricardo Lewandowski, o ensino religioso não pode visar o proselitismo, enquanto objetivo, explícito 
ou velado, de conversão dos alunos a alguma confissão específica. Para honrar seu dever de laicidade, o Estado precisa zelar para que os currículos ofertados sejam suficientemente imparciais e equilibrados ou, quando se tratar do ensino de uma confissão específica, oferecêlo de forma facultativa, institucionalizando a possibilidade de dispensa do aluno sem que este venha a sofrer qualquer tipo de desvantagem, discriminação ou estigma.

Sublinha Lewandowski que não existe qualquer tipo de incompatibilidade entre democracia e religião no Estado laico, ao contrário ambas podem e devem ser parceiras na busca do bem comum, especialmente no desenvolvimento de uma sociedade plural e compreensiva para com as naturais diferenças entre os seus integrantes. O conceito de laicidade no Brasil, ressalta o ministro, assim como em outros países, embasa-se no tripé tolerância, igualdade e liberdade religiosa. Trata-se, acima de tudo, de um princípio constitucional voltado à proteção das minorias que, graças à separação entre o Estado e a Igreja, não podem ser obrigadas a submeter-se aos preceitos da religião majoritária.Elucida também que essa separação entre o Estado e a Igreja não constitui, é importante destacar, quer no Brasil, quer em outros países, uma muralha que separa cosmovisões incomunicáveis. Se assim fosse, não seriam admissíveis a menção explícita a Deus no preâmbulo de nossa Constituição, os feriados religiosos, o descanso dominical e muitas outras manifestações religiosas institucionalizadas pelo Poder Público, como, por exemplo, a aposição do crucifixo no plenário da mais alta Corte do País.Salienta o ministro que a inviabilidade de abrigar-se todas as igrejas e confissões em uma única escola não afasta a possibilidade de ministrar-se o ensino confessional ou interconfessional, já que tal dificuldade aplica-se igualmente ao ensino secular. À toda evidência, jamais haverá condições fáticas para ofertar-se aos alunos o ensino de todas as religiões e disciplinas práticas ou teóricas que existem, uma vez que elas não constituem um "numerusclausus".

Em tom de finalização, entende o ministro Ricardo Lewandowski que, certamente, se o ensino religioso referido no art. $210, \S 1^{\circ}$, da Carta Política ostentasse sempre o caráter secular, humanista, filosófico e histórico tal como aventado na inicial proposta pela PGR, razão não existiria para garantir-se, em nível constitucional, a sua facultatividade, cujo papel fundamental é evitar a submissão dos alunos a conflitos de lealdade entre as convicções religiosas ou laicas de seus pais - principais responsáveis pela educação dos filhos - e as religiões lecionadas na escola, além de salvaguardar o caráter pluralista e democrático da educação estatal.

No rol de votos vencidos, tiveram destaque aqueles proferidos pelos ministros Celso de Mello e Edson Fachin, de modo que passo a abordá-los. Conforme explicita o ministro 
Celso de Mello, a pretensão estatal de reprimir ou de cercear a liberdade de expressão, inclusive em matéria confessional, é perigoso e nocivo, ainda que se pretenda, no campo da liberdade religiosa, assim, “A livre expressão de ideias, pensamentos e convicções, em sede confessional, não pode e não deve ser impedida pelo Poder Público, nem submetida a ilícitas interferências do Estado"(MELLO 2017a. p. 9)Conforme esclarece Mello, na visão filosófica de Espinosa, tornava-se claro que assuntos de teologia e questões de Estado revelavam-se matérias que não deveriam confundir-se, pois tinha ele, por incontestável, que nem a teologia deveria subordinar-se à razão de Estado nem essa ao pensamento teológico. Isso porque as convicções no domínio religioso pertencem, exclusivamente, ao plano da razão individual e ao foro íntimo de cada ser humano, que é, no âmbito da religião, a suprema autoridade. A necessária delimitação entre a esfera religiosa, que concerne ao espírito, e o domínio secular, que é regido pelo Estado, constitui fator, por excelência, da liberdade humana.

Enfatiza Celso de Mello que é com o advento da República que se consagrou o princípio básico da laicidade estatal, estabelecendo, assim, a separação orgânica entre o Estado e a Igreja, de modo a tratar, de um lado, da esfera secular ou temporal, e de outro, da esfera espiritual. Para Mello, a República também consolidou a ideia de neutralidade do Estado em matéria confessional, no sentido de que o Poder Público não possui preferência, nem aversão, a qualquer denominação religiosa; e a exigência de respeito incondicional à liberdade religiosa, de maneira que o exercício religioso não pode sofrer qualquer interferência estatal, seja para favorecer aquele que a exerce ou aquele que opta por não professar religião alguma, seja para prejudicá-los.

Em matéria confessional, portanto, segundo o ministro Celso de Mello e em conclusão à fundamentação de seu voto, o Estado brasileiro há de manter-se em posição de estrita neutralidade axiológica, em ordem a preservar, em favor dos cidadãos, a integridade do seu direito fundamental à liberdade religiosa. Destaca Celso de Mello a função contramajoritária do Poder Judiciário, em particular a do Supremo Tribunal Federal, no Estado Democrático de Direito. Esclarece, nesse contexto, que o fato de o Catolicismo constituir, hoje, a religião preponderante no Estado brasileiro não autoriza que se produza, em nosso País, um quadro de submissão de grupos confessionais minoritários à vontade hegemônica da maioria religiosa, o que comprometeria, gravemente, o postulado da laicidade do Estado e de todos os seus demais consectários, pois, ninguém o ignora, o regime democrático não tolera nem admite a opressão de qualquer minoria, inclusive a religiosa, por grupos confessionais majoritários. 
Também acompanhando o voto vencido do ministro relator Luís Roberto Barroso, o ministro Edson Fachin inicia sua argumentação afirmando que a posição mais conforme à configuração do Estado Laico é a que estabelece uma nítida separação entre Estado e Igreja, pautada na neutralidade em matéria religiosa e na própria garantia de liberdade religiosa perpassa ainda pela ideia de que o direito ao ser afirmado por um Tribunal é aquele resultante de uma pluralidade de compreensões, esclarecendoque, nesses casos, a solução deve ser aquela que melhor se amolda à fundamentação democrática do estado constitucional, devendo, pois, dar primazia à pessoa humana, com base no princípio pro homine, mas ter em conta também o valor igual de cada pessoa em dignidade.

Afirma o ministro Edson Fachin que a sustentação teórica de sua posição se encontra em John Rawls, ao definir o conceito de razão pública, invocando a dimensão epistêmica do procedimento deliberativo, estabelecendo que: a plena ação do nosso poder político será plenamente devida no momento em queé exercida de acordo com uma constituição. Nesse contexto, entende Fachinque há, no direito à liberdade de religião previsto em nosso texto constitucional e também nos Pactos Internacionais de São José da Costa Rica e de Direitos Civis e Políticos, uma dimensão pública, sendo certo que o pluralismo democrático não prescinde, pois, de convicções religiosas particulares, estando a religião no papel de condição de verdadeira existência, conforme reconhecido pela Corte Europeia dos Direitos Humanos. Entretanto, apesar de ser incorreto se afirmar que a dimensão religiosa coincide apenas com o espaço privado, não se admite que se justifique a fundação do espaço público com base em convicções religiosas.Assim, enfatiza Edson Fachin que a escola deve espelhar o pluralismo da sociedade brasileira, se configurando como um microcosmo da participação de todas as religiões e também daqueles que livremente optaram por não ter nenhuma. Afirma, em suas palavras, "que a escola deve promover a sua responsabilidade para com o Outro, que, como lembra Álvaro Ricardo de Souza Cruz, não se limita ao ateísta ou ao religioso" (FACHIN2017b, p. 6).Esclarece o ministro Fachin, que o seu objetivo ao expor seus argumentos, é não só afastar práticas inconstitucionais de exclusão que muitas vezes são autorizadas sob o fundamento da laicidade, como também permitir a afirmação dos direitos das minorias religiosas.Fachin atesta que, conforme diz Jacques Derrida, não há nada efetivamente secular no mundo atual, mas reconhece que a democracia, enquanto permanente autocrítica sobre a própria Constituição, pode um dia se tornar secular.

Por fim, o STF julgou improcedente o pedido formulado na ADI $n^{\circ} 4439$, na qual a PGR alegavaa inconstitucionalidade do ensino religioso confessional diante da laicidade. Foram vencedores os votos dos ministros Alexandre de Morais, Carmem Lúcia, Edson 
Fachin, Dias Toffoli, Gilmar Mendes e Ricardo Lewandowski. Os votos vencidos foram proferidos pelo relator, ministro Roberto Barroso, seguido dos ministros Rosa Weber, Luiz Fux, Marco Aurélio de Mello e Celso de Mello. A posição vencedora, apresentada pelo ministro Alexandre de Morais concluiu que o ensino religioso nas escolas públicas brasileiras pode ter natureza confessional, de modo a ser comprometido com a profissão de fé de diversas religiões.Sob o ponto de vista comunitarista, entretanto, a decisão impõe desafios à isonomia, na medida em que não garante adequadamente o igual reconhecimento a todas as manifestações religiosas, que é devido no Estado laico.

\section{Identidade e Reconhecimento sob o viés Comunitário}

Conforme esclarece Roberto Gargarella(2008, p. 140), o comunitarismo se baseia em uma noção de liberdade "situada" que confere importância a questões como onde estou e para onde vou. Isso porque o comunitarismo pressupõe que a construção da identidade ocorre dentro de uma determinada sociedade. De modo diverso, os liberais se baseiam em uma ideia vaga de liberdade segundo a qual o ser humano é um ser autônomo e, dessa forma, não há horizontes culturais a serem seguidos.O liberalismo puro defende a neutralidade do Estado, a vida pública se resume no resultado "espontâneo" do consenso entre os indivíduos. A neutralidade estatal não se compromete com a proteção de determinados grupos sociais.

$\mathrm{Na}$ concepção comunitarista, o Estado deve, de forma ativa, se comprometer e assegurar modos de vida que se direcionam ao bem-estar social. Para Patrícia Mattos (2006, p.136), o autor comunitaristaCharles Taylor percebe que o Estado não é eticamente neutroe, por essa razão, ele defende a necessidade de que o Estado liberal assuma políticas multiculturalistas de proteção aos grupos minoritários.O Estado não deve ser indiferente aos laços entre os indivíduos da mesma comunidade nem adotar uma posição ontológica "atomista" que compreenda o ser humano como autossuficiente no espaço moral, sem conexão com alguma determinada identidade comunitária.

No âmbito mais propriamente político, o conceito de liberdade trabalhado por Taylor é essencial para as pretensões de uma sociedade que se constitui fora de quaisquer ordens transcendentes, incluindo aí o Estado. Charles Taylor ultrapassa a visão do indivíduo centrado em si mesmo, descolado do mundo. Conforme o autor: "Alguns aspectos da política atual estimulam a necessidade ou, por vezes, a exigência, de reconhecimento. Pode-se dizer que a necessidade é, no âmbito da política, uma das forças motrizes dos movimentos nacionalistas. E a exigência faz-se sentir, na política de hoje, de determinadas formas, em nome dos grupos 
minoritários ou subalternos, em algumas manifestações de feminismo e naquilo que agora, na política, se designa por Multiculturalismo".

A efetivação de políticas públicas que reconheçam as distintas identidades culturais se tornou, na sociedade moderna, condição para se concretizar o reconhecimento do outro. Todavia, o Estado liberal nem sempre responde a tais exigências, se mostrando inerte às políticas que asseguram a identidade de grupos sociais.Nossa identidade é constituída dentro de uma narrativa histórica que antecede a nós mesmos e desconstruir estes horizontes resultaria numa certa desorientação para se definir o que é certo ou errado, que é bom ou ruim.

Nesse contexto, Taylor pretende encontrar um equilíbrio entre a noção liberal do ser humano, que encontra em si mesmo sua identidade humana, e a tese social comunitarista que considera o ser humano um animal social, no sentido aristotélico. Para tanto, o filósofo canadense defende que,para a construção da autenticidade moderna, é substancial garantir determinada comunidade política que o constitui. Afirma ainda ser necessária uma análise crítica sobre a primazia de direitos individuais em face aos direitos que amparam a comunidade como um todo.

Gargarella (2008, p. 144-145) compreende que a diversidade cultural, enquanto pluralidade de grupos étnicos, religiosos, dentre outros, com singulares formas de localização e direção moral convivendo em um mesmo espaço público, gerou tensões e antagonismos sociais nos Estados modernos. A filosofia política contemporânea tem como foco estudar o fenômeno do multiculturalismo, a fim de compreender e propor soluções que assegurem, promovam, ou mesmo limitem os indivíduos no espaço público. O foco de atenção sobre o estudo do multiculturalismo se encontra na diversidade cultural (língua e religião, por exemplo) e considera a "dificuldade do pensamento liberal" em articular soluções satisfatórias aos desafios oriundos desta diversidade de identidades nas sociedades contemporâneas. Gargarella faz uma análise da ligação entre o comunitarismo e o multiculturalismo.

Para os críticos do liberalismo, o Estado puramente liberal deve se manter inerte em relação à proteção da diversidade. Os liberais esclarecem que o Estado não deve se comprometer frente a qualquer minoria cultural. Dentre as razões desta crítica se encontra o tratamento histórico dado a minorias culturais e a primazia aos direitos subjetivos, em detrimento a direitos de grupos culturais. Há, de certa forma, o pressuposto liberal de que a autonomia pessoal precede a sociedade cultural.

Neste sentido, Gargarella (2008, p. 160-161)alude que os liberais não reconhecem como um problema a desconstrução de determinada cultura ou ritual tradicional. Ao se tornar 
neutro, o Estado não adota políticas públicas que asseguram e promovem as distintas formas de cultura presentes no Estado moderno. Contudo, certo é que o Estado liberal não é capaz de responder, de forma adequada, às demandas do multiculturalismo.

Sobre as demandas do estado moderno, em especial a demanda de proteção e promoção das distintas culturas que formam a identidade do indivíduo moderno, "o liberalismo mostra sua resistência a reconhecer como válidas aquelas reivindicações feitas em nome de certas minorias desfavorecidas" (GARGARELLA, 2008, p. 160-161). Resta claro, para Gargarella, a incompatibilidade entre o liberalismo e as preocupações próprias do multiculturalismo, havendo um profundo vínculo que une o "multiculturalismo" ao comunitarismo. Cabe ressaltar que o multiculturalismo se encontra comprometido com o reconhecimento das minorias, questionando noções como a homogeneidade cultural e o nacionalismo.

Como pensador comunitarista, o filósofo Charles Taylorpercebe que o próprio liberalismo não é neutro plenamente, ele traça uma dicotomia entre a possiblidade de polarização excludente e os tipos de compreensão da diferença. Taylor entende que se faz necessário um diálogo hermenêutico entre as distintas culturas. É neste contexto que Taylor busca em Gadamer o conceito de fusão de horizontes. Isso porque a hermenêutica pode ser uma resposta adequada a este desafio que é o multiculturalismo.

A compreensão da importância da cultura para a formação da identidade, conforme Taylor, perpassa pela ideia de que os seres humanos são formados dialogicamente, os indivíduos são dialógicos por natureza. Nossa identidade é formada pela alteridade, pelo outro. $\mathrm{O}$ autor ressalta a importância cultural dentro de uma sociedade, já que a cultura forma a identidade do ser humano em determinado tempo e espaço geográfico. Taylor aborda o ideal moderno da autenticidade e o associa ao multiculturalismo:

As fontes do self moderno são multiculturais e Taylor analisa a formação da autenticidade pelas culturas locais, e secundariamente pelos valores individuais. Pressuposto intrínseco à formação do self é o reconhecimento da identidade, modo pelo qual a sociedade conceitua e atribui valor a um indivíduo ou grupo social. A política do reconhecimento da identidade no estado liberal é uma luta pela diferença.

Conforme Mattos (2006, p.11): “[...] a luta pelo reconhecimento é também uma afirmação da diferença, uma vez que ela pede o reconhecimento da identidade específica de grupos". Taylor (1994, p. 92) alerta que "a política da diferença poderá acabar por tornar as pessoas iguais"acarretando a homogeneização do ser humano, mas a política de reconhecimento de identidade pressupõe as distintas maneiras de ser, de identidade, não nos 
faz iguais e "a mera diferença não pode ser em si mesma o fundamento do valor igualitário"(TAYLOR, 2011, p. 59).

Para o autor canadense, a identidade se forma, em parte, pelo reconhecimento ou pela falta dele. O reconhecimento errôneo pode gerar aos indivíduos ou coletividades um "verdadeiro dano, autêntica deformação se o povo ou a sociedade que os rodeiam lhe mostram, como reflexo, um quadro limitativo, ou degradante ou depreciável de si mesmo" (TAYLOR, 1993, p. 43).

Nota-se a importância que Taylor dá ao reconhecimento correto para a formação da identidade. Nesse ponto, o autor canadense propõe a ética da autenticidade e a articula com uma política do reconhecimento como uma alternativa de resolução dos problemas morais e políticos do mundo contemporâneo.

A noção de autenticidade se encontra na nossa liberdade de articular, nos horizontes culturais, de modo substancial, singular e dialógico, nossa identidade, que é constituída junto ao intercâmbio com outros significantes da comunidade. Nesta perspectiva, verificamos a intrínseca conexão com a ética da autenticidade no plano social, amparado por políticas públicas de reconhecimento. Charles Taylor (2000b, p. 12) se lança a analisar em dois níveis distintos como se dá o devido reconhecimento a uma determinada cultura na sociedade democrática multicultural:"na esfera íntima, onde a formação da identidade e do ser é entendida como fazendo parte de um diálogo e lutas permanentes como os outrosimportantes" e, na esfera pública, a política do reconhecimento igualitário se tornou fundamental.O reconhecimento que se encontra inserido na esfera pública cuida de uma análise ampla de direitos iguais entre os povos e entre grupos minoritários contra a discriminação.

\section{A ADIN 4439 sob a ótica Comunitarista}

Charles Taylor (2000b, p.250) elabora uma noção de igualdade no intuito desolucionar as demandas pelo reconhecimento das diferentes particularidades nas democracias contemporâneas. Segundo o autor canadense, a política do reconhecimento tende a evitar o universalismo meramente formal da dignidade, sob o risco danegação das diferenças. A igualdade deve ser pautada nas diferenças que nos constituem como seres 
humanos, pois é na singularidade dos indivíduos que residem o reconhecimento do outro e o reconhecimento de si mesmo. Dessa forma, a igualdade depende do reconhecimento social das identidades, dos diferentes modos como cada pessoa se define.A igualdade para Taylor tem como pressuposto a proteção e promoção de grupos culturais religiosos, étnicos e outros.

A concepção de dignidade humana leva a uma política universalista de igualdade entre os indivíduos da sociedade.Enquanto valor moral legítimo, a dignidade compõe, no imaginário social, a política do universalismo, tendo como epicentro o respeito igual a todos os seres humanos e a equidade dos direitos.

O não reconhecimento histórico de determinados grupos repercute na impossibilidade de igualdade material universal, devido às desigualdades sociais e econômicas atuais. A política da diferença preconiza medidas de discriminação reversa (positiva) pois,ao reconhecer a diferença de oportunidades, são criadasalternativas mais favoráveis no intuito de se alcançar a igualdade material.

As políticas do universalismo e da diferença, se arguidas unilateralmente, não solucionam as disparidades sociais, pois não alcançam e não promovem os elementos constitutivos de valor. Assim, essas duas modalidades de política, ambas baseadas na noção de respeito igual, podem entrar em conflito. Para uma delas, o princípio do respeito igual requer que tratemos as pessoas de uma maneira cega às diferenças, porque ela se concentra naquilo que é o mesmo em todos. Para a outra, temos de reconhecer e mesmo promover a particularidade. Taylor (2000a, p.254) diz que a reprovação que a primeira faz à segunda é simplesmente que ela viola o princípio de não-discriminação, e a reprovação que a segunda faz à primeira é a de que ela nega a identidade ao impor às pessoas uma forma homogênea que é infiel a elas.

Aparentemente, ao reconhecer a constitucionalidade do ensino confessional nas escolas públicas, o STF buscou promover as diferentes religiões, entretanto a decisão não assegurou suficientemente a igualdade entre os diferentes credos religiosos. Neste sentido, a decisão do Supremo traz inúmeros desafios à isonomia porque não atentou para as dificuldades concretas impostas pela inviabilidade de contratação pela administração pública de representantes de todas as religiões.

Conforme dados do IBGE de 2010, no Brasil 92\% dos entrevistados professam uma determinada religião, que segundo o Novo Mapa das Religiões possui mais de 140 denominações. No mundo atual, multicultural e globalizado, se conjectura a existência de mais de 4 (quatro) mil religiões. Desta forma, a decisão do STF fragiliza a liberdade religiosa porque, como efeito colateral, acaba privilegiando algumas religiões em detrimento de outras. 
O Estado laico, pautado pela liberdade religiosa, deve reconhecer a importância de se assegurar e promover igualmente todas as identidades culturais religiosas, uma vez que estas orientam indivíduos no espaço público. Neste sentido, as normas que tratam da laicidade, da liberdade religiosa e do ensino religioso precisam viabilizar a todas as religiões iguais possibilidades de reconhecimento. Como é inviável promover o ensino religioso confessional de mais de 140 denominações religiosas - dados aproximados sobre o Brasil -, acaba-se negando reconhecimento das identidades religiosas minoritárias.

Com isso, aumentama desigualdade eo desrespeitoà liberdade religiosa dos grupos não favorecidos. A este respeito, vale lembrar que, conforme os dados da Secretaria de Direitos Humanos da Presidência da República, no Brasil, em 2016, foram registradas 759 denúncias de violações à liberdade religiosa. O número representa aumento de quase 37\% com relação ao ano anterior. Umbanda e candomblé são as religiões de quase $19 \%$ do total das vítimas. Em seguida, aparecem outras religiões de matriz africana e o espiritismo.O levantamento da Secretaria Estadual de Direitos Humanos mostra que o Estado do Rio de Janeiro registrou 800 atendimentos de intolerância religiosa em 2017. A média é de dois casos por dia e, na maioria das vezes, as vítimas são praticantes de religiões de matriz africana.

Os tipos de intolerância mais praticados são discriminação, depredação, difamação e invasão. Praticantes do Candomblé, Umbanda e outras religiões de matriz africana correspondem a $71,5 \%$ dos atendimentos. Já os católicos correspondem a 9\%, evangélicos 6\%, e islâmicos, 3\%. Em 2011 foram registradas 15 denúncias. Em 2012, o número aumentou para 109 registros. Já em 2016, foram 759 casos.De janeiro a junho de 2017, o Disque 100 registrou 169 denúncias de intolerância religiosa. Deste total, a maioria das ocorrências $(39,05 \%)$ teve como vítimas praticantes de candomblé, umbanda e demais religiões de matriz africana. Serviço de utilidade pública do Ministério dos Direitos Humanos (MDH), a ferramenta recebe demandas relativas a violações de Direitos Humanos.

\section{Conclusão}

Valendo-se do pensamento comunitarista de Charles Taylor, a pesquisa buscou confrontar os postulados da isonomia e da liberdade religiosa com a decisão do STF que atestou a constitucionalidade do ensino religioso confessional em escolas públicas. A primeira parte do texto apresentou considerações sobre a laicidade no Estado brasileiro e sobre a ADI $\mathrm{n}^{\mathrm{o}} 4439$ que solicitava interpretação conforme de dispositivo da LDB e do artigo $11, \S 1^{\circ}$ do 
acordo firmado entre o Brasil e a Santa Sé. No julgamento, o STF enfrentou três questões: se o ensino religioso nas escolas públicas pode ser vinculado a religião específica; se é admissível professores na qualidade de representantes das confissões religiosas em escolas públicas; se a disciplina deveria ser voltada para a história e a doutrina das várias religiões.Ao julgar pela improcedência da ADI, o Supremo interpretou que a laicidade prevista no artigo 19, I, da Constituição não obsta a promoção e a otimização da liberdade religiosa $\left(\mathrm{CF}, \mathrm{Art}\right.$. $5^{\circ}$, $\mathrm{VI})$.

A segunda parte do texto tratou do comunitarismo de Charles Taylor, estabelecendo uma ligação entre reconhecimento e identidade. Para o autor, o homem constitui sua identidade pela cultura, por isso as fontes da identidade individual e coletiva contemporânea são diversas, seculares e até conflitantes entre si. Nesta perspectiva comunitarista, se exige do Estado políticas públicas de reconhecimento que garantam a isonomia entre as distintas identidades culturais religiosas e, por conseguinte, assegurem adequadamente a liberdade religiosa.

A terceira parte do texto analisou a decisão do STF que afirmou a constitucionalidade do ensino confessional nas escolas públicas. Foi apontado que o ensino confessional pode potencializar desigualdades já existentes no espaço público entre as distintas culturas religiosas, acarretando falta de reconhecimento a grupos minoritários. A decisão do STF pretendeu abraçar concepções multiculturalistas, entretanto acabou renegando-as, na medida em que não assegurou adequadamente o reconhecimento das diferentes identidades culturais. Neste sentido, o ensino público confessional fere a isonomia por causa da inviabilidade de que todos os credos religiosos tenham professores contratados pela rede pública de educação.

Conclui-se, portanto, que o ensino religioso nas escolas públicas não deve estar vinculado a qualquer religião específica, em virtude da impossibilidade fática dese admitir professores que sejam representantes de todas as confissões religiosas que existem. Logo a disciplina Religião deve ser facultativa e voltada para a história e a doutrina das várias religiões, a fim de se evitar assimetrias entre os diferentes credos religiosos.

\section{Referências Bibliográficas}

BARBOSA, Rui. Obras Completas de Rui Barbosa. V. 4, t. 1, 1877a.

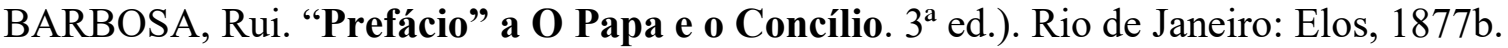


BARBOSA, Ruy. Obras Seletas, Vol. 7. Rio de Janeiro: Imprensa, 1898.

BRASIL. Supremo Tribunal Federal. Ação Direta de Inconstitucionalidade (ADI) n. 4439/Distrito Federal (DF).Relator: Roberto Barroso. Voto - Ministro Celso de Mello. Diário

Oficial da União. Brasília: DF, 2017a.p. 1-43. Disponível em: $<$ http://www.stf.jus.br/arquivo/cms/noticiaNoticiaStf/anexo/ADI4439mCM.pdf $>$. Acesso em: 5maio. 2018.

BRASIL. Supremo Tribunal Federal. Ação Direta de Inconstitucionalidade (ADI) n. 4439/Distrito Federal (DF).Relator: Roberto Barroso. Voto - Ministro Edson Fachin. Diário Oficial da União. Brasília: DF, 2017b. Disponível em: $<$ http://www.stf.jus.br/arquivo/cms/noticiaNoticiaStf/anexo/VotoFachinEnsinoReligioso.pdf $>$ . Acesso em: 4maio 2018.

BRASIL. Supremo Tribunal Federal. Ação Direta de Inconstitucionalidade (ADI) n. 4439/Distrito Federal (DF).Relator: Roberto Barroso. Voto - Ministra Carmém Lúcia. Diário Oficial da União. Brasília: DF, 2017c. Disponível em: $<$ http://www.stf.jus.br/portal/cms/verNoticiaDetalhe.asp?idConteudo=357099\&caixaBusca $=$ $\mathrm{N}>$. Acesso em: 4 maio 2018.

BRASIL. Supremo Tribunal Federal. Ação Direta de Inconstitucionalidade (ADI) n. 4439/Distrito Federal (DF).Relator: Roberto Barroso. Voto - Ministro Alexandre de Moraes. Diário Oficial da União. Brasília: DF, 2017d. Disponível em: $<$ http://www.stf.jus.br/arquivo/cms/noticiaNoticiaStf/anexo/ADI4439AM.pdf $>$. Acesso em: 4 maio 2018.

GARGARELLA, Roberto. As teorias da justiça depois de Rawls. Um breve manual de filosofia política. São Paulo: WMF Martins Fontes, 2008.

GUALDA, Diego de Lima. Individualismo Holista: uma articulação crítica do pensamento político de Charles Taylor. Dissertação (Mestrado em Ciências Políticas) - Faculdade de Filosofia, Letras e Ciências Humanas, Universidade de São Paulo, São Paulo, 2009, p. 259260. Disponível em: <http://www.teses.usp.br/teses/disponiveis/8/8131/tde-05022010095325/pt-br.php>. Acesso em 03 maio 2018

LAFER, Celso. A reconstrução dos Direitos Humanos: um diálogo com o pensamento de Hannah Arendt. São Paulo: Companhia das Letras, 1988.

MATTOS, Patrícia. A sociologia política do reconhecimento: as contribuições de Charles Taylor, Axel Honneth e Nancy Fraser. São Paulo: Annablume, 2006.

SARMENTO, Daniel. O crucifixo nos Tribunais e a laicidade do Estado. Revista Eletrônica PRPE, v. 5, p. 1-17, 2007.

SILVEIRA, Carlos Frederico; ROCHA, Felippe Augusto da Cruz; CARDOSO, Rafael Esteves. A ética da autenticidade na concepção multiculturalista de Charles Taylor. Lex Humana, Petrópolis, v. 4, n. 2, 2012. p. 26. Disponível em: $<$ http://seer.ucp.br/seer/index.php?journal=LexHumana\&page=article\&op=view\&path $\% 5 \mathrm{~B} \%$ 5D $=275 \&$ path $\% 5 B \% 5 \mathrm{D}=187>$. Acesso em: 8 maio. 2018. 
TAYLOR, Charles. A ética da autenticidade. São Paulo: É Realizações, 2011.

TAYLOR, Charles. Multiculturalismo: examinando a política de reconhecimento. Lisboa: Instituto Piaget, 1994.

TAYLOR, Charles. Multiculturalismo y la política delreconocimiento: ensaio de Charles Taylor. México: Fondo de Cultura Económica, 1993.

TAYLOR, Charles. Propósitos entrelaçados: o debate liberal-comunitário. In: TAYLOR, Charles. Argumentos Filosóficos. São Paulo: Loyola, 2000a.

TAYLOR, Charles. A política do reconhecimento. In: TAYLOR, Charles. Argumentos filosóficos. São Paulo: Loyola, 2000b.

Censo Demográfico 2010: Características gerais da população, religião e pessoas com deficiência. em: http://biblioteca.ibge.gov.br/visualizacao/periodicos/94/cd_2010 religiao deficiencia.pdf.

Novo Mapa das Religiões, elaborado pelo Centro de Políticas Sociais da FGV em 2011, com base em dados do IBGE de 2009.

\section{O sagrado feminino: Percepções de gênero na tessitura histórica no campo religioso}

The sacred feminine: Perceptions of gender in the historical setting in the religious field

Clera de Faria Barbosa Cunha ${ }^{15}$ barbosaclera@gmail.com

Claudia de Faria Barbosa ${ }^{16}$ barbosa.claudiadefariabarbosa@gmail.com

Resumo: Este artigo parte da discussão mitológica, com a ideia de deuses e deusas para problematizar questões religiosas de dominação de gênero na sociedade contemporânea. $\mathrm{O}$ objetivo é problematizar para compreender e analisar aspectos históricos em torno do sagrado a partir das relações de gênero. O percurso metodológico recai na docência de ensino religioso em um contexto que se propõe laico (Brasil, 1988) e, na perspectiva de pedagogias ativas trabalha aspectos da história das religiões, na qual a mulher reconhecida como deusa nas religiões politeístas é despojada do seu poder de divindade, dando espaço ao predomínio do patriarcado, com o surgimento das religiões monoteístas. Percebe-se a ânsia dos estudantes por compreender os fatos, o que faz despertar o interesse pela busca de conhecimentos no campo das ciências da religião.

Palavras-chave: Sagrado feminino. Ensino Religioso. Educação laica.

${ }^{15}$ Mestre em Educação e Sociedade, Pedagoga, especialista em Ensino Religioso, Psicopedagogia, Educação Inclusiva, Docência no Ensino Superior, Planejamento, Implementação e Gestão da Educação a Distância, Gestão Escolar. Supervisora Escolar e Professora de Ensino Religioso do Colégio Tiradentes PMMG.

${ }^{16}$ Doutora e Mestre no Programa em Família na Sociedade Contemporânea (UCSAL), Professora da UniRuyI Wynden, e Universidade Estadual do Sudoeste da Bahia (UESB). Pesquisadora do Grupo de Estudos Hermenêuticos em Família, Território, Identidades e Cultura (GEHFTIM). 
Abstract: This article is part of the mythological discussion, with the idea of gods and goddesses to problematize religious issues of gender domination in contemporary society. The objective is to problematize to understand and analyze historical aspects around the sacred from the relations of gender. The methodological course relies on teaching religious teaching in a context that proposes to be secular (Brazil, 1988) and, in the perspective of active pedagogy works aspects of the history of religions, in which the woman recognized as a goddess in polytheistic religions is stripped of her power of divinity, giving space to the predominance of patriarchy, with the emergence of monotheistic religions. The students' eagerness to understand the facts is evident, which arouses interest in the search for knowledge in the field of the sciences of religion.

Keywords: Sacred feminine. Religious education. Lay education

\section{Contextualização: o conceito de sagrado e as percepções nos primórdios da história}

Para vislumbrar ou encontrar a Grande Mãe, precisamos apenas abrir nossas mentes, descartar os preconceitos e os condicionamentos sócio-culturais e criarlhe um espaço sagrado, em nosso coração e em nossa vida (Mirella, 2001).

A humanidade se constituiu no decorrer da história com conceitos criados pelos humanos, de acordo com suas inquietações, na ânsia de explicar o mistério da vida e da morte. Do mito à razão, muitas são as possibilidades e crenças vividas até chegar ao que se tem atualmente, sobre o sagrado e o profano.

A noção de sagrado opõe-se ao profano e trás a dicotomia: deuses e demônios. Conforme o dicionário de Ciências Humanas (Dortier, 2010, p. 570), a partir dos anos 1950 essas ciências vão globalmente centrar em práticas, ritos, instituições e papel das religiões ao invés de atribuir sentidos meramente espiritualistas ao sagrado. Trata-se de uma simbolização da vida na qual o sagrado refere-se ao divino eterno e imutável, enquanto o profano é temporal e perecível. "É sagrado àquilo que se refere à perpetuação da vida, maldito o que ameaça a sobrevivência. Seja assumindo a figura do 'destino' ou do 'absoluto', o sagrado, teria, portanto, a função de encarnar a 'vida', ou seja, a permanência dos seres".

Trazer a ideia do sagrado feminino para a discussão pressupõe pensar a ideia de criação. De acordo com Mirella (2001), milhares de anos atrás, a Grande Mãe era a origem de toda a criação. Considerada uma figura complexa, andrógena por auto fertilizar-se, ela tanto criava a vida como era a própria vida. A deusa contém o deus em sua totalidade; ela é a terra e ele é sua força, o princípio dinâmico e criativo que resplandece, definhha e reacende. Trata-se de uma relação de complementaridade, na qual juntos representariam a criação.

Entretanto, pensar a história e tentar entendê-la em um contexto de divindades, respeitando a laicidade, urge libertar-se das amarras do senso comum em que o peso das 
paixões envolvem as crenças e desperta às condutas transmitidas de geração a geração sobre o sagrado, sem necessariamente instituir a separação dos poderes, mas resignificá-los com equilíbrio.

Conforme Rosado-Nunes (2005), historicamente a produção do que é 'sagrado' nas diversas sociedades faz parte da dominação masculina que é reverberada em discursos e práticas religiosas. As mulheres são maioria nas religiões, estão presentes nesses espaços, mas são ausentes quando se trata de demarcar fronteiras definidoras das pautas e das políticas organizacionais e pastorais das instituições religiosas. Ou seja, estão presentes, mas somente alcançam espaços de representatividade e liderança abaixo dos homens. Ou seja, "o investimento da população feminina nas religiões dá-se no campo da prática religiosa, nos rituais, na transmissão, como guardiãs da memória do grupo religioso".

Há nesse ínterim, um jogo de dominação que perpassa pelas relações de gênero no contexto histórico de dominação. Badinter (1986) compreende que ao pensar a mulher como o Outro, não é renunciar à relação de reciprocidade entre os sexos, e também não é considerá-la como essencial, mas perceber que por terem podido constituir um grupo separado, dotado de poderes específicos, as mulheres conseguiram ter relações relativamente autônomas com os homens e não apenas relações de submissão, como se evidencia nos silêncios da história.

Nesse contexto paradigmático de um novo repensar do sagrado, o qual se refere a fenômenos de pensamento complexos que envolvem pontos de vistas variados e requer o equilíbrio das forças ocultas em busca de construir a "transcendência, fundamentalmente, é essa capacidade de romper todos os limites, superar e violar os interditos, projetar-se sempre num mais além". (Boff, 2000, p. 8).

Transcender, ir além do cada um pode imaginar, ser um sujeito pensante que sonha e que vai em busca desse sonho é característica de todo ser humano. A escola como um espaço de aprendizagem e de socialização, deve proporcionar aos seus alunos essa busca constante, por mudanças e transformações.

E, no decorrer das buscas às respostas, por um longo período histórico, a humanidade tenta entender os mistérios do sagrado, que não necessariamente retrata as questões de gênero, discutidas na contemporaneidade. Para efeito de domínios patriarcais não somente seria necessário dividir o poder sobrenatural, entre divindades masculinas e femininas, uma vez que a natureza era considerada a deusa de todos, com as suas particularidades divinas, mas pressupor e fazer-se acreditar em um Deus forte, característica que não coaduna com a suposta fragilidade das mulheres. Esse pressuposto não combina com o que Bolen (1990) 
atribui a Grande Deusa que era venerada como a força da vida feminina, profundamente relacionada com a natureza e a fertilidade, responsável pela criação da vida e sua destruição.

Nesses conflitos, o pensamento humano cruza nos fios da memória deixada como legado aos seus progenitores e confunde com sua complexidade o recriar dos pormenores que se fixam por caminhos tortuosos ampliando os conhecimentos, mas também as dúvidas, através de investigações presentes nas crenças simbólicas, lendas e mitos meios encontrados de desenvolver, criar e recriar o significado da vida estabelecendo o conceito de Deusa Mãe, como mais um mito.

O primeiro conceito sobre a divindade foi expresso por nossos ancestrais na forma da Grande Mãe geradora, nutridora e sustentadora de todos os seres, recebendo-os de volta em seu ventre após sua morte para trazê-los novamente à vida. A Deusa foi a suprema divindade do nosso planeta durante cerca de 30.000 anos, reverenciada e conhecida sob inúmeras manifestações e nomes, conforme os lugares e períodos de seus cultos. Suas múltiplas qualidades e funções foram descritas em todas as culturas, originando as lendas e os mitos que mostram uma diversidade de deusas que, contudo, eram aspectos de uma só divindade: a Grande Mãe (Mirella, p. 16, 2001).

Através das necessidades advindas das peculiaridades humanas, referentes à criação e a disputa de poder das sociedades, ressurgem hipóteses em torno das divindades.

De acordo com o mitólogo e historiador Robert Graves, antes das religiões patriarcais a Grande Deusa era tida como imortal, constante e onipotente. Sucessivas ondas de invasões dos indo-europeus iniciaram o destronamento da Grande Deusa. As datas que marcam o início desses acontecimentos, segundo várias autoridades, são fixadas entre 4500 e 2400 antes de Cristo. As deusas não foram completamente suprimidas, mas incorporadas nas religiões dos invasores. Os invasores impuseram sua cultura patriarcal e sua religião bélica aos povos conquistados. A Grande Deusa tornou-se a consorte serviçal dos deuses dos invasores (Bolen, p. 208, 1990)

Para Mirella (2001) a deusa passou a ser mulher, filha ou concubina dos deuses trazidos pelos povos guerreiros e conquistadores que foram tomando espaço e o feminino foi subjugado e dominado pelo masculino. Em se tratando do mistério e, na busca das respostas, as religiões se desenvolveram, na medida que explicam, de maneira também inexplicável, os enigmas que não são entendidos pelos humanos.

Os atributos e poder que originalmente pertenciam à divindade feminina foram desapropriados e dados a uma divindade masculina. A violação apareceu nos mitos pela primeira vez, e surgiram mitos nos quais os heróis do sexo masculino matavam serpentes, símbolos da Grande Deusa. E, como se reflete na mitologia grega, os atributos, símbolos e poder que um dia foram investidos numa Grande Deusa, foram divididos entre muitas deusas (Bolen, p. 208, 1990). 
No processo de redescobrir o que é inexplicável frente à inteligência humana, os mitos religiosos procuram explicar como a força masculina foi ganhando espaço e as peculiaridades femininas, espalhadas entre as diversas deusas foram, aos poucos, se eximindo e deixando o recinto do poder aos que se faziam prevalecer, por meio da dominação que se estendia por boa parte do território.

\begin{abstract}
Os mitos falam diretamente à mente consciente, ao subconsciente e ao consciente coletivo. Muitos temas básicos são repetidos em diferentes mitos ao redor do mundo. Muitas histórias semelhantes aparecem em culturas bem distantes umas das outras. Os mitos são como mapas que podem nos proporcionar o entendimento da relação dos seres humanos com o mundo dos deuses e sua própria natureza, bem como sua forma de atuação dos deuses no mundo. Os mitos são formas de nos conhecermos interiormente. Quando lemos e conhecemos mais profundamente os mitos, observamos simbolismos relacionados a eles. Como mapas podem nos indicar quem somos, porque estamos aqui e para onde caminhamos (Prieto, p. 15, 2015).
\end{abstract}

No transcorrer dos séculos, as lendas e mitos que representam o simbólico ganham espaços nas religiões, na tessitura da história que concomitantemente envolvem o pensamento humano, em busca das explicações, em torno do sagrado e do profano.

\title{
Escola: Espaço de inquietações e busca de novos paradigmas
}

\section{"O homem do futuro será incompreensivel se não tivermos compreendido o homem do passado". A. Leroi Gourhan}

Na ânsia de encontrar respostas, retomar a história, estudar os fatos, lendas e mitos, sem necessariamente julgá-los, mas entendê-los no seu contexto, faz-se com que as observações antigas aprimorem os dados atuais, não descartando as possibilidades de complementar e ampliar os conhecimentos na compreensão do passado que se faz presente.

Nesse sentido, pensar e analisar a figura simbólica do sagrado feminino dentro do contexto da educação pública no Brasil é, na realidade, acreditar que vale a pena compreender as disputas de poder e omissões em torno do sagrado e do profano. "O passado conserva-se e, além de conservar-se atua no presente, mas não de forma homogênia" (Bosi, 1994, p. 48). Trata-se não somente de lembrar e reviver o passado, mas de esforçar-se para reconstruir os fatos diante das possibilidades de compreensão atuais.

Para Morin (2001) compreender o humano é abarcar sua unidade na diversidade e sua diversidade na unidade. É conceber a unidade do múltiplo e a multiplicidade do uno. Nesse 
sentido, analisa-se o conceito do sagrado, sendo este, fruto da criação humana que tenta se explicar através das religiões.

Quando se trata de explicações vindas das religiões, vale ressaltar a importância de pensá-las em um contexto laico, sem necessariamente julgá-las ou condená-las. E, a escola é este espaço dialético, dedicado ao processo formativo, ou seja, lócus destinador à educação por excelência. Entendida como direito individual humano e coletivo, implica considerar o seu poder de habilitar para o exercício dos direitos, potencializar o ser humano como cidadão pleno, de tal modo que este se torne apto a viver e conviver, nos diversos ambientes (Brasil, 2010).

Acredita-se que para atingir a compreensão do sagrado feminino na tessitura da história há de retornar aos fatos e problematizar junto com os sujeitos envolvidos, a trajetória dos dogmas e tradições religiosas, independente de suas origens, mas com respeito à pluralidade cultural dos diferentes modos de se compreender o mundo e vivê-lo.

\section{A liberdade de crença em um país laico}

"Toda educação saudável é uma educação sem controle religioso" Erasmo de Roterdã (1466-1536)

Os fatos históricos ajudam a compreender os movimentos e os interesses que levaram ao modelo de educação atual, nas escolas públicas brasileiras, que emergem de uma história de desigualdades, alimentada pelas atitudes daqueles que mantém o monopólio do ensino.

A laicidade no Brasil perpassa por lutas e resistências, uma vez que foi implantada de maneira que o Estado se propusesse distanciar das religiões. Para que essa premissa surtisse efeito haveria a necessidade de começar pelas escolas e a universalização do ensino favoreceu, porque houve necessidade de acesso das classes menos privilegiadas à educação pública, única, dita laica e gratuita sob a responsabilidade do Estado.

De fato, a luta pela nova política educacional teve seus princípios garantidos na Constituição Federal, que estabelece em seu art. 210, parágrafo $1^{\circ}$ "O ensino religioso, de matrícula facultativa, constituirá disciplina dos horários normais das escolas públicas de ensino fundamental" (Brasil, 1988). Com essa promulgação, após oito anos foi aprovada a Lei de Diretrizes e Bases da Educação Nacional, n. 9.394/96, que estabelece em seu art. $3^{\circ}$ :

O ensino religioso, de matrícula facultativa, constitui disciplina dos horários normais das escolas públicas de ensino fundamental, sendo oferecido, sem ônus para os cofres públicos, de acordo com as preferências manifestadas pelos alunos ou por seus responsáveis em caráter: 
I confessional, de acordo com a opção religiosa do aluno ou do seu responsável, ministrado por professores ou orientadores religiosos preparados e credenciados pelas respectivas igrejas ou entidades religiosas;

II interconfessional, resultante de acordo entre as diversas entidades religiosas, que se responsabilizarão pela elaboração do respectivo programa. (Brasil, 1996)

Com a vigência da referida lei e, através de questionamentos a respeito de seu artigo 33, foi aprovado o seu substitutivo com a edição da lei 9.475/97, passando o ensino religioso como disciplina escolar e como área do conhecimento integrante na formação básica do cidadão.

O ensino religioso, de matrícula facultativa, é parte integrante da formação básica do cidadão e constitui disciplina dos horários normais das escolas públicas do ensino fundamental, assegurado o respeito à diversidade cultural e religiosa do Brasil, vedadas quaisquer formas de proselitismo. (Brasil, 1986)

O relator da lei 9.475 (Brasil, 1997), Padre Roque Zimmermann, afirma que pela primeira vez na história da educação brasileira foram criadas oportunidades de sistematizar o Ensino Religioso como componente curricular que não fosse doutrinação religiosa.

Para efetivar essa educação laica no contexto escolar e diante do que foi proposto nas normas vigentes, não houve preocupação dos sistemas de ensino em adaptar os materiais para o desenvolvimento do trabalho e, nem mesmo, a capacitação de professores para lidarem com a diversidade humana presente em sala de aula, ou seja, um público que está em busca do conhecimento, mas muitas vezes, sem saber distinguir a importância desse processo pedagógico no seu cotidiano.

Curry (2004) chama atenção para o que representa o ensino religioso como componente curricular nas escolas. "Por trás dele se oculta uma dialética entre secularização e laicidade no interior de contextos históricos e culturais precisos". Em muitos séculos de história, até os dias atuais, a religião apresenta um paradoxo, por um lado ajuda as pessoas a viverem melhor e encontrarem esperanças, mas é inegável que é utilizada para excluir e dividir grupos. A existência de polêmicas em torno da intolerância religiosa tem sido motivo de sofrimentos e de guerras, seja na cultura local e regional como também na global.

As discussões sobre a proposta do que ensinar na disciplina ensino religioso nas escolas públicas passam por instabilidades sociais, marcadas por interesses contraditórios e fatos históricos, atrelados às atitudes daqueles que mantém o monopólio do ensino, na realidade conduz ao modelo de educação existente atualmente.

Diante de tantas instabilidades em um país predominantemente cristão, na busca de entender e praticar a laicidade na escola pública os alunos e professores buscam alçar o 
conhecimento. Conforme Bourdieu (1999) o que importa, realmente, é que a escola seja capaz de reinventar-se a cada momento para poder ser uma resposta adequada aos desafios que lhe vêm de um mundo em constante transformação, e não uma instituição legitimadora das desigualdades, onde os dominados aplicam categorias construídas do ponto de vista dos dominantes às relações de dominação, fazendo-as assim ser vistas como naturais.

O fundamental não é mais fazer funcionar a escola, mas impregná-la da consciência da necessidade de sua constante invenção pela modificação de seus paradigmas, de seu projeto, de sua forma e de sua estrutura. "O ideal da sabedoria já não descreve mais aquele que detém todos os conhecimentos passados, mas aquele que procura e investiga" (Valle, 1997, p. 74).

\section{Aspectos metodológicos, campo pesquisado e discussões}

As características presentes nas diversidades humanas e refletidas na escola estimulam o sujeito a procurar respostas às indagações que surgem na sua existência e, como ser de busca ele se interroga. Quem sou eu? De onde venho e para onde vou? Estas perguntas se encontram nos escritos de filósofos como Sócrates, Platão e Aristóteles. Para além dessas, se pergunta quem é o mentor da vida? Existe deus, deuses, deusa ou deusas? São questões nas quais as respostas se imprimem efetivamente dependendo da orientação que tem sobre existência humana. E o ensino religioso presente nos currículos de formação na educação básica em escola pública pode oferecer suportes a essas interrogações? Nesse sentido, propõese uma pesquisa através da observação participante, no contexto da disciplina de ensino religioso, com alunos dos anos finais do ensino fundamental de escola pública.

A proposta é problematizar conteúdos para compreender e analisar aspectos históricos em torno do sagrado a partir das relações de gênero. O percurso metodológico recai sob a disciplina de ensino religioso na qual os universos culturais se misturam por conta da diversidade humana, em um contexto que se propõe laico.

Assim, entender o mito da deusa é compreender a essência de sua sabedoria. Mitos sempre foram considerados histórias de ensinamentos pelos povos antigos. Eles trazem imagens simbólicas, revelações de mistérios. (Prieto, p.15, 2015).

E, a escola, como espaço de construção e de socialização do conhecimento tem dupla função: trabalhar com os conhecimentos humanos sistematizados, historicamente produzidos e acumulados e criar novos saberes. Sabe-se que nem todo conhecimento é de interesse de todos, mas uma vez produzido é patrimônio humano e como tal deve estar disponível e a escola não pode recusar-se a socializá-lo. Lembrando que, por questões éticas e religiosas não 
é função da escola propor aos educandos a adesão e vivência desses conhecimentos. (PCN, 2009.p. 35).

Em meio ao ensinar e aprender existe uma caminhada que vai sendo construída aos poucos entre professor e aluno. Nesse processo encontra-se a troca de conhecimentos que desperta uma didática satisfatória na compreensão do mundo e da vida. Assim, a mediação pedagógica vai se fazendo aos poucos, constituindo-se em uma metodologia que satisfaça aos anseios dos educandos no decorrer do processo educacional.

Viesser (1994) chama a atenção pelo fato de que em meio a interesses sociais, políticos, econômicos, culturais e ideológicos está o professor de ensino religioso que enfrenta os limites das relações de poder entre igreja, entidades, grupos religiosos e a escola, controlada pelo Estado. E, nesse contexto o professor confronta-se com sua consciência de educador que lhe indica a necessidade de desenvolver em seus educandos a capacidade de desvelar a vida e construir às perspectivas do futuro.

Cabe à escola trazer questões para os alunos pensarem, investigarem e produzirem seus próprios conhecimentos, ou seja, transcenderem-se em meio ao desconhecido. Nessa perspectiva, o ensino religioso tende a ser uma reflexão crítica sobre a práxis que estabelece significados, considerando que a dimensão religiosa passa a ser compreendida como compromisso histórico, diante da vida e do transcendente. E contribui para o estabelecimento de novas relações do ser humano com a natureza a partir do progresso da ciência e da técnica (PCN, 2009).

Recorrer à criação e a reinvenção dos estudantes são estratégias de aprendizagem importantes, ao invés de insistir em práticas dos conteúdos dados prontos e sua atomização. Problematizar dá lugar à descoberta e a criação favorecendo a compreensão de conteúdos, sua generalização e, sobretudo, sua aplicabilidade em um mundo marcado por jogos de poder e intolerâncias.

Conforme Chakur (1995) também seria tarefa do educador, em uma pedagogia ativa, enfatizar a transformação significativa "antes que no observável, no descritível e na configuração estática". Ou seja, há de privilegiar o aspecto operativo da cognição, apelar para a compreensão, imaginação, criação e interpretação dos estudantes, ao invés de manter o hábito, a repetição e a reprodução. Não é simples, mas é possível trazer os mitos, o simbólico para explorar mais a criatividade e imaginação dos alunos para pensar questões que desembocam nas ciências e, sobretudo, nas religiões.

\section{Considerações finais}


Há que se destacar as diversas instabilidades sociais refletidas na escola por seres em formação. Consequentemente, o trabalho com a disciplina de ensino religioso tem papel fundamental no intuito de aprofundar a reflexão sobre os valores arraigados na tradição histórica da humanidade, a fim de torná-la livre e consciente.

No processo educacional em escola pública, faz-se necessário o desenvolvimento de atitudes laicas, sem necessariamente deixar de demonstrar respeito pelas diferentes culturas e crenças religiosas, com a intenção de contribuir com o aprendizado, não reprimindo o desejo do aluno de conhecer.

Destaca-se a contraditória situação de alunos que pensam saber os pormenores da história, mas estão arraigados em seus pensamentos instituídos por uma sociedade que se autodetermina como correta nos traços simbólicos do patriarcado. Muitas vezes, percebe-se a ideologia presente em seus ditos e não ditos, que são ignorados por razões imponderáveis, como se fosse algo complementar que viesse sanar a fragilidade das identidades, sobretudo nas relações de gênero.

\section{Referências}

BADINTER, Elisabeth. Um é o outro; relações entre homens e mulheres. 2 ed. Rio de Janeiro: Nova Fronteira, 1986.

BOFF, Leonardo. Tempo de Transcendência: O Ser Humano como Projeto Infinito. Sextante, 2000. p. 8. Publicações Eletrônicas. Lumensana. Disponível em: $<$ http://pt.scribd.com/doc/2951200/Tempo-de-Transcendencia-Leonardo-Boff $>$. Acesso em 5 outubro 2018.

BOLEN, Jean Shinoda. As deusas e a mulher. Nova psicologia das mulheres. São Paulo: Paulus, 1990.

BOURDIEU, P. A dominação masculina. Rio de janeiro: Bertrand Brasil.1999.

BOSI, Eclésia. Memória e sociedade. Lembranças de velhos. 12ed. São Paulo: Companhia das letras, 1994.

BRASIL. Constituição da República Federativa do Brasil. Brasília: Senado Federal, 1988. (1996). Lei de Diretrizes e Bases da Educação Nacional, n. 9394. Estabelece as diretrizes e bases da educação nacional. Brasília: Senado Federal, 1996. Disponível em: < http://www.planalto.gov.br/ccivil_03/leis/L9394.htm > Acesso em 2 de outubro 2018.

, (1997). Lei n. 9.475. Dá nova redação ao art. 33 da Lei n. 9.394, de 20 de dezembro de 1996, que estabelece as diretrizes e bases da educação nacional. Disponível em: $<$ http://www.pedagogiaemfoco.pro.br/19475_97.htm > Acesso em: 14 out. 2018.

. (2010). Diretrizes Curriculares Nacionais Gerais para a Educação Básica,

2010. Parecer do Conselho Nacional de Educação. Disponível em: $<$ http://portal.mec.gov.br/index.php?option=com_content\&view=article\&id=12992:diretriz para-a-educacaobasica\&catid=323:orgaos-vinculados $>$ Acesso em 14 outubro 2018.

CHAKUR, Cilene Ribeiro de Sá Leite. Fundamentos da prática docente: por uma pedagogia ativa. Paidéia, Ribeirão Preto, n. 8-9,p. 37-52,Agosto 1995. Disponível em: 
$<$ http://www.scielo.br/scielo.php?script=sci_arttext\&pid=S0103-

863X1995000100004\&lng=en\&nrm=iso $>$. Acesso em 6 novembro 2018.

CURY, Carlos Roberto Jamil. Ensino religioso na escola pública: o retorno de uma polêmica recorrente. Revista Brasileira de Educação. Rio de Janeiro, n. 27, dez. 2004 . Disponível em: $\quad<\quad$ http://www.scielo.br/scielo.php?script=sci_arttext\&pid=S1413$24782004000300013 \& \operatorname{lng}=$ pt\&nrm=iso $>$. Acesso em 10 outubro 2018.

DOTIER, Jean-Francois. Dicionário de Ciências Humanas. Revisão e coordenação da tradução Márcia Valéria Martinez de Aguiar. São Paulo: Martins Fontes, 2010.

MIRELLA, Faur. O Anuário da Grande Mãe: guia prático de rituais para celebrar a Deusa. 2ed. São Paulo: Gaia, 2001.

MORIN, Edgar. O método 5: a humanidade da humanidade. Porto Alegre: Sulina, 2002.

ROSADO-NUNES, Maria José. Gênero e Religião. Estudos Feministas. Florianópolis, 13(2): $363 \quad-\quad 365$, maio - agosto/2005. Disponível em: $<$ http://www.scielo.br/pdf/ref/v13n2/26888.pdf > . Acesso em 5 outubro 2018.

PARÂMETROS CURRICULARES NACIONAIS. (PCN) Ensino Religioso. Fórum Nacional Permanente do Ensino Religioso. São Paulo: Mundo Mirim, 2009.

PRIETO, Claudiney. Todas as Deusas do mundo. Rituais Wiccanianos para celebrar a Deusa em suas diferentes fazes. São Paulo: Ardane, 2015.

VALLE, Llian do. A escola imaginária. Rio de Janeiro: DP\&A, 1997.

VIESSER, Lizete Carmem. Um paradigma para o ensino religioso. Petrópolis, RJ: Vozes, 1994. 


\title{
Professores do Rio de Janeiro e seus relatos de intolerâncias e discriminações às religiões afro-brasileiras
}

\author{
Teachers of Rio de Janeiro and their reports of intolerance and discrimination to the afro- \\ brazilian religions
}

\author{
Marcos Porto Freitas da Rocha ${ }^{17}$ \\ porto.marcos@gmail.com \\ José Geraldo da Rocha ${ }^{18}$ \\ rochageraldo@hotmail.com \\ Antônio José de Figueiredo Pinto ${ }^{19}$ \\ psichologus@hotmail.com
}

Resumo: Trata-se análise através de entrevistas semi-estruturadas com professores das redes pública e privada do Estado do Rio de Janeiro cujos relatos de experiência permitiram compreender a realidade de professores que declaram ser de religiões afro-brasileiras em seu cotidiano em escolas. É possível descrever as reações que ocorrem por sua postura de declaração de fé enquanto realizam suas atividades em conformidade com a legislação vigente, e agindo de forma empática com seus educandos, não se furtando de expressar parte importante de sua formação cultural que é a religião e sua relação com o(s) (T)transcendente(s), com a exceção da que omite sua fé para não ser alvo de discriminação aberta em sua atuação em escola privada confessional. Sendo alvo de discriminação e preconceitos velados ou não em suas escolas. Auxiliando colegas e alunos a lidar com estas situações que são comuns e até naturalizadas em algumas instituições.

Palavras-Clave: Religião na escola, Diversidade religiosa, Preconceito religioso, Religião afro-brasileira.

\begin{abstract}
It is an analysis through semi-structured interviews with professors from the public and private networks of the State of Rio de Janeiro whose experience reports allowed to understand the reality of professors who declare to be of Afro-Brazilian religions in their daily life in schools. It is possible to describe the reactions that occur because of their statement of faith as they carry out their activities in accordance with current legislation, and act empathically with their students, not failing to express an important part of their cultural formation, which is religion and their relationship with the transcendent ( $s$ ), with the exception of the one who omits their faith so as not to be openly discriminated against in their private confessional school performance. Being discriminated against and prejudiced veiled or not in their schools. Helping colleagues and students deal with these situations that are common and even naturalized in some institutions.
\end{abstract}

Keywords: Religion in school, Religious diversity, Religious prejudice, Afro-Brazilian religion.

\footnotetext{
${ }^{17}$ Prof. Ms. Marcos Porto Freitas da Rocha. Doutorando e Mestre em Humanidades Culturas e Artes pelo Programa de Pós-Graduação em Humanidades Culturas e Artes da Universidade do Grande Rio, Especialista em Ciências da Religião pela Faculdade São Bento do Rio de Janeiro e Bacharel em Teologia pelo Instituto Metodista Bennet/RJ. Professor UNIGRANRIO / Assistente em Administração UFRJ.

${ }^{18}$ Prof. Dr. José Geraldo da Rocha. Bolsista de Produtividade em Pesquisa 1'a-UNIGRANRIO/FUNADESP, Prof. Adjunto Dr. no Programa de Pós-Graduação em Humanidades, Culturas e Artes. Líder do Grupo de Pesquisa Relações Raciais, Desigualdades Sociais e Educação-CNPq.

${ }^{19}$ Prof. Ms. Antônio José de Figueiredo Pinto. Mestre em Educação, Especialista em Gestão de Recursos Humanos. Psicólogo Clínico e Organizacional, Especialista em Ciências da Religião. Doutorando no Programa de Pós-Graduação em Humanidades, Culturas e Artes. Professor de Ensino Religioso na SEDUC-RJ.
} 


\section{Introdução}

Neste artigo apresentaremos pesquisa bibliográfica baseada em análise de dados levantados pelos relatos de experiência produzidos pelos pesquisadores Eduardo Quintana, Ana Paula Mendes de Miranda, José Geraldo da Rocha e suas equipes através de entrevistas semi-estruturadas, que nos permitiram compreender um pouco da realidade de professores que declaram ser de religiões afro-brasileiras no seu cotidiano em escolas municipais, estaduais e privadas do Rio de Janeiro. É possível apresentar alguns dos problemas enfrentados por eles em seu dia-a-dia e quais a reações que ocorrem por sua postura de declaração de fé.

Todas as servidoras públicas são estáveis e realizam suas atividades em conformidade com a legislação vigente, e que, conforme apresentados em seus relatos, exercem empatia com seus educandos e não se eximem de expressar parte importante de sua formação cultural que é a religião e sua relação com o transcendente, ao contrário da participante que exerce suas funções em uma escola privada do Rio de Janeiro, que declara ter de omitir sua fé para não ser alvo de discriminação aberta.

\section{Conceição: Candomblé como grande escola}

O professor Eduardo Quintana descreve Maria da Conceição, ou apenas Conceição como Filha de Oxum, mulher negra, heterossexual, 47 anos, solteira e sem filhos e ocupa o cargo de equéde ${ }^{20}$. Integra terreiro situado na Zona Norte do Rio de Janeiro. Reside com o pai, operário, em bairro da Zona Sul do Rio de Janeiro desde que nasceu. Graduada em História da Arte em uma universidade privada confessional na Zona Sul do Rio de Janeiro e é professora de Educação Artística nas redes municipal e estadual de ensino do Rio de Janeiro.

Ela afirma que há muito preconceito contra os praticantes de religiões afro-brasileiras na escola, isto os faz sentir-se intimidados quanto a assumir sua orientação religiosa. Declara ainda que esta lógica também ocorre na relação entre pares. Observa que nos últimos anos, nas escolas onde há maior número de professores evangélicos, os docentes adeptos do candomblé se sentem discriminados e que isto acontece com a anuência dos diretores.

\footnotetext{
${ }^{20} \mathrm{Na}$ hierarquia feminina dos candomblés, acólita voluntária de um orixá, quando este baixa numa filha de santo [Ajudam-na a se vestir com os trajes sagrados do orixá, amparam-na durante o transe etc.].
} 
Contudo, na escola em que leciona isso é diferente em razão da ação firme do diretor contra esse tipo de postura.

Recorda-se de que quando se iniciou, trabalhava em duas escolas, uma católica, na Zona Sul do Rio de Janeiro, e outra da rede pública estadual, no bairro de Campo Grande. Na escola católica, segundo ela, nunca teve problemas com sua orientação religiosa. Porém, essa relação de respeito não se repetia na escola pública, onde sofreu discriminação por parte dos professores evangélicos. Afirmando inclusive que os três meses seguintes a sua iniciação foram muito difíceis, não apenas em decorrência da citada discriminação mencionada, mas no que se refere à sua relação com os outros professores. No caso dos professores evangélicos, a relação era distante, ela não conseguia se aproximar, pois havia resistência da parte deles (QUINTANA, 2013). Este período de aprendizado ajudou a desmistificar a relação de intolerância que pensava existir em escolas católicas, nele desconstruiu os valores éticos e morais que acreditava ainda existirem na escola pública.

Considera que o candomblé é uma grande escola, pois ensina a seus praticantes que as pessoas têm qualidades e defeitos e, por esta razão não se deve emitir juízo de valor. Acredita que é o candomblé e não a escola que tem ensinado aos seus praticantes a lidar com a diferença e a se relacionar com as outras religiões.

Questionada sobre ser função da escola ensinar os alunos a conviverem com a diferença, como parte dos objetivos da Lei $n^{0} 10.639$ (BRASIL, 2003) e das diretrizes curriculares nacionais para a educação das relações etnicorraciais e para o ensino de história e cultura afro-brasileira e africana (BRASIL, 2005), enfatizou que isto não acontecia. Conceição considera que a lei não contempla as religiões afro-brasileiras, encobrindo este tipo de religiosidade, pois não acredita ser possível estudar a África sem mencionar suas divindades. A existência pura e simples da Lei $n^{\circ} 10.639$ e das diretrizes curriculares não leva a termo o processo de aceitação das religiões afro-brasileiras por parte da escola.

Quanto a não observância das necessidades religiosas dos alunos praticantes das religiões afro-brasileiras pela escola, observa que a frequência no terreiro pode atrapalhar a escola, porque esta não quer adequar o seu calendário às datas litúrgicas dessas religiões:

[Conceição] Você vê o menino faltar porque ele tem que ficar recolhido três meses, vai atrapalhar, sim, a escola. Quanto às festas, isso também atrapalha. Eu também acho que a escola não foi feita para receber ninguém de candomblé. Se você faz o santo ou tem que ir numa festa importante na sua Casa, não está incluído em lei nenhuma que você pode faltar (QUINTANA, 2013, p. 131). 
Esta é uma questão de não aceitação de um universo religioso, que está muito além dos objetivos propostos por uma educação inclusiva e não apenas meramente legal. Segundo o relato de Conceição, na rede pública de ensino, a expressão que mais tem ouvido ao longo dos anos é: "Quem mandou o aluno(a) fazer o santo?" (QUINTANA, 2013, p. 132). A comunidade escolar, ao agir assim, demonstra o desrespeito pela religiosidade do discente. Numa instituição onde o aluno judeu, o católico e o evangélico são respeitados, o praticante do candomblé não.

Quanto ao calendário escolar, ela entende que deveria haver flexibilidade entre as demandas do calendário escolar e as necessidades do aluno. A escola, sem alterar seu calendário, tem de adotar uma postura democrática e aberta, em que respeite a diversidade existente em seu interior. Aplicar a Lei $\mathrm{n}^{\mathrm{o}} 10.639$, de forma a propiciar uma verdadeira inclusão do aluno praticante das religiões afro-brasileiras.

[Conceição] Uma pessoa para fazer o santo precisa, no mínimo, de 21 dias... Eu acho que poderia, sim, sem abuso. Ele poderia fazer as provas. Fala-se em igualdade, então eu acho que tem que ter sim, uma "leizinha" que possibilitasse esse aluno, esse candomblecista, fazer o santo e voltar a estudar sem perder o ano. Aqui, na escola, tem um aluno que fez santo e, graças a Deus, ele não perdeu o ano. [...] Também tem professores que mantêm certo distanciamento. Professores que chegam a debochar da situação do aluno: "Ele dá prioridade pro santo, ele deita pro santo" [fazer obrigação]. Eu já escutei isso (QUINTANA, 2013. p. 132).

A partir de suas declarações, é possível perceber a existência de um currículo que internaliza os valores de uma matriz religiosa judaico-cristã numa vertente mais radical. $\mathrm{O}$ aluno praticante das religiões afro-brasileiras tem o direito de afirmar seus valores sociais e culturais pela vestimenta, vocabulário e expressão corporal. Sendo a escola responsável por zelar para que os colegas de outros credos não o ridicularizem.

\section{Eloah: o ensino religioso é perigoso}

Na pesquisa de Quintana, é identificada como nascida e criada em um bairro da Zona Norte da cidade do Rio de Janeiro, essa filha de Oxalá, que integra um terreiro situado na Zona Norte da cidade do Rio de Janeiro, 46 anos, homossexual, branca, sem filhos, que declara ter uma companheira com quem vive maritalmente há vários anos. Bióloga, professora de Ciências nas redes municipal e estadual do Rio de Janeiro, há aproximadamente 20 anos. 
Em sua experiência como professora, ao ser questionada quanto à Lei ${ }^{\circ} 10.639$ (BRASIL, 2003) e das Diretrizes Curriculares Nacionais para a Educação das Relações Etnicorraciais e para o Ensino de História e Cultura Afro-Brasileira e Africana (BRASIL, 2005) afirmou que, mesmo antes de esta existir, já abordava temas relacionados às culturas africana e afro-brasileira, procurando inserir em suas atividades alguma expressão em yorubá acompanhado da respectiva tradução, o que causava estranheza nos alunos:

[Eloah] E eles ficam olhando: “O que é isso professora?” Eu respondia: “É a língua dos nossos ancestrais. Aqui tem algum branco total?" Eu brinco com eles: "A gente é tudo vira-latas. Ninguém aqui tem pedigree. Ninguém aqui tem 'raça pura'; aqui é tudo misturado". "Essa é a língua que veio lá da África. A língua de alguns dos nossos ancestrais. Por isso que é legal a gente conhecer" (QUINTANA, 2013, p. 133)

Com isso, conseguia introduzir discussão o tema, partindo de uma preocupação pessoal, pois, no currículo das escolas, não havia orientação nesse sentido.

Segundo dados da pesquisa, há dois anos, Eloah desenvolveu um projeto, em conjunto com outros professores, cujo objetivo era realizar a Semana da Consciência Negra na escola. Neste, cada professor deveria apresentar uma atividade que atendesse aos objetivos propostos pelas Diretrizes Curriculares Nacionais para a Educação das Relações Etnicorraciais e para o Ensino de História e Cultura Afro-Brasileira e Africana (BRASIL, 2005). Ela normalmente propunha uma tradução de um texto em ioruba, cujo objetivo era inserir elementos da cultura africana e afro-brasileira, ampliando o conhecimento dos alunos sobre essa etnia.

[Eloah], nós não podemos chegar e dizer: "Vamos esquecer esse povo, porque eu não tenha nada com esse povo". Eu sempre bato nessa tecla com os alunos. Porque eu trabalho com alunos de comunidade e você não vai achar um aluno de comunidade que não tenha um pezinho lá na África. E é muito por aí (QUINTANA, 2013, p.134)

Esta proposta deu resultados, mas não teve continuidade por não ter havido apoio da parte da direção e coordenação pedagógica. Eloah ressaltou o fato de que o currículo praticado nas escolas brasileiras, mesmo com a Lei $\mathrm{n}^{\circ} 10.639$, continua deixando em segundo plano, temas relativos à presença africana no Brasil. E a questão religiosa passa ao largo desta discussão.

Sobre a sua pertença religiosa, declara que os professores que se assumem praticantes das religiões afro-brasileiras têm medo de sofrer algum tipo de represália ou retaliação, pois o problema não está na implementação da Lei no 10.639 e, sim, no Ensino Religioso. Afirma 
que a forma como o Ensino Religioso é ministrado nas escolas da rede estadual é algo muito perigoso e que ela tem muito medo da perseguição velada aos adeptos do candomblé e da umbanda:

[Eloah] A gente já não pode dizer que nós somos candomblecistas. A maioria se diz espírita. Eu não sou espírita, eu sou candomblecista. Mas a maioria se diz espírita ou católico, como forma de se proteger (QUINTANA, 2013, p. 134).

Na rede estadual do Rio de Janeiro, o Ensino Religioso apresenta uma tendência muito grande de doutrinação, segundo Eloah, o que contraria o Artigo 5 da Constituição Federal (BRASIL, 1998). Aponta um caso, que demonstra o grau de intolerância de algumas escolas da rede pública do Rio de Janeiro:

[Eloah] nós já vimos [sic\} acontecer com um garoto que havia feito o santo e foi supermaltratado na escola. A professora o chamava de "filho do diabo". É muito complicado, é muito perigoso. [...] A gente tem que ter muito cuidado, da forma como a religião é tratada nasescolas. [...] Tá errado, cada um tem o direito de ter a sua religião, escolher o que é melhor para si (QUINTANA, 2013, p. 135).

Segundo Pedro Oro, (2007) a demonização religiosa não é uma inovação do catolicismo brasileiro. Mesmo tendo havido rejeição das religiões afro-brasileiras, seus rituais e crença, pela igreja católica ao longo de séculos na história brasileira, hoje pode ser observado que é travada uma espécie de guerra santa praticada por algumas igrejas neopentecostais, tendo por base uma teologia surgida na década de 80 no meio evangélico norte-americano, que propõe a demonização das religiões não cristãs.

A permanência no magistério para ela acabou por se tornar uma questão de sobrevivência e cumprimento de tempo para se aposentar. Os constantes enfrentamentos estavam fazendo com que desacreditasse da escola, focando toda a sua experiência de mais de 25 anos de magistério em seu terreiro de candomblé, onde pretende desenvolver projetos sociais:

[Eloah]. Quando eu me aposentar, aí vai ser o meu tempo só para Oxalá. E aí eu tenho um sonho. Eu quero que a casa funcione mais como um lugar gerador de coisas para a comunidade. Eu moro nos pés do Morro do Angu e eu gostaria que a Casa fosse mais atuante para ajudar essas pessoas. Mas eu não quero dar uma cesta básica, eu quero ensinar (QUINTANA, 2013, p. 135).

\section{Jamila: oyá é a razão de sua vida}


A terceira entrevistada por Quintana é Jamila de Oyá que integra um terreiro situado em Itaguaí, RJ. Formada em Educação Física, é professora da rede pública do Rio de Janeiro. Afirma que o fato de ser praticante e usar vestimentas próprias e camisetas alusivas aos orixás e fio de contas no pescoço, possibilita aos alunos que se aproximem dela para conversar, algo que não acontece com os outros professores:

[Jamila] pelo fato de eu ser da religião, os alunos conversam comigo: "Professora, você é de candomblé?" Teve um dia, que eu fui com uma camisa que tinha estampada a figura de Oxum. Aí, a aluna veio: “Ih, professora, eu raspei...”. Aí, vem e conversa. Eles se aproximam para falar. Primeiro, eles percebem, ou porque viu o fio de contas no meu pescoço, ou pela roupa branca, eles se aproximam para falar (QUINTANA, 2013, p. 136).

Declara acreditar que nos encontramos diante da formação de redes de sociabilidade estabelecidas com fim específico de proteção, tecida pela mediação dos vínculos com o universo religioso afro-brasileiro possibilitando a interação do indivíduo com o grupo, a partir da percepção de que estas envolvem: além dos conteúdos, a própria valorização de suas ações. Desse modo, as formas resultantes destes processos ganham vida própria, libertas dos conteúdos e existindo por si mesmas, constituindo a sociabilidade, que transforma associação em um valor apreciado em si (SIMMEL, 2006).

A entrevistada chama a atenção para as estratégias adotadas por professores praticantes ou relacionados ao universo religioso afro-brasileiro. Tomando o exemplo do Conselho de Classe em que esses professores procuram ajudar os alunos que praticam religiões afro-brasileiras, no intuito de abonar as faltas decorrentes de sua frequência ao terreiro. Ela afirma que as reuniões se transformam em verdadeiros embates, pois alguns professores argumentam que a religião não pode ser usada como justificativa, ignorando, ou mesmo negando a religiosidade desses alunos:

[Jamila] eu acho que isso é um problema de intolerância mesmo. Na escola que eu trabalho, a diretora é superflexível. Ela é evangélica, tem os princípios dela, mas ela é superflexível, ela aceita bem. Mas, a gente sabe que tem lugares que há esta discriminação (QUINTANA, 2013, p. 137).

\section{A professora de Macaé}


Trata-se de professora de língua portuguesa e inglesa, Ana ${ }^{21}$, pós-graduada em português e latim pela Universidade do Estado do Rio de Janeiro (UERJ) e em africanidades pela Fundação Educacional de Macaé (FUNEMAC). Trabalhava há 8 oito anos em uma escola pública em Macaé e após curso de Afrocartografias ${ }^{22}$ oferecido pela prefeitura deste município começou a trabalhar a temática afro-brasileira em sala de aula. Mulher de 54 anos, branca, de olhos e cabelos claros, autodeclarada umbandista, que em seu relato afirma nunca ter havido problema de relacionamento com os professores e diretores que trabalhavam na escola, apesar de serem em maioria evangélicos. Enfatizou que sempre expressou sua religião na escola sem enfrentar qualquer dificuldade relacionada a isto. (MIRANDA et al, 2011).

Ministrava aulas de literatura e gramática nas quais abordava a temática indígena, esclarecendo que ainda não havia utilizado a cultura e história africana nas aulas. Porém, um aluno sugeriu a utilização do livro Lendas de $\mathrm{Exu}^{23}$, encontrado por ele na biblioteca da escola. Tendo analisado o livro paradidático e verificado que possuía certificação do Ministério da Educação brasileiro, utilizando-o sem problemas com uma turma do sexto ano. Utilizou uma metodologia que consistia na leitura do livro e discussão sobre os mitos e lendas da África com o interesse de desconstruir uma imagem negativa do personagem Exu (MIRANDA et al, 2011),, outra atividade em aula seria a de cada aluno desenhar as representações de Exu como um personagem das narrativas do livro.

Dois meses depois de utilização do livro como ferramenta de abordagem da cultura e história afro-brasileira, iniciaram-se os conflitos, o que coincidiu com o pedido de realização de atividades relativas ao livro como deveres de casa.

Em pesquisa documental foram analisados o processo administrativo onde registra-se que o Diretor adjunto recebeu reclamações de responsáveis referentes à atuação da professora em sala, que este, inicialmente, considerou que poderia estar havendo algum tipo de preconceito dos pais em relação à professora, devido sua confissão de fé de religião afrobrasileira. Contudo, ante ao aumento e intensificação das reclamações, iniciou averiguação que o conduziu a concluir que o conteúdo abordado em sala não se tratava de literatura afrobrasileira, mas sim "místico religioso".

\footnotetext{
${ }^{21}$ Nome alterado para resguasdar a identidade dos participantes.

${ }^{22}$ Este curso foi um incentivo em prol de atender a lei 11.645/08 que prevê o ensino transversal, ou seja, em diversas disciplinas, no currículo escolar, da história e cultura africanas nas salas de aulas das escolas públicas.

${ }^{23}$ Livro de Adilson Martins, publicado pela Editora Pallas em 2005, que narra diversas histórias sobre o personagem Exu, da mitologia africana e afro-brasileira, em comparação com outros seres mitológicos com as mesmas características como Loki (Nórdica), Hermes ou Mercúrio (grega ou romana) e outros, ou folclóricos como Saci, Pedro Malasartes etc.
} 
Foi realizada uma reunião com a professora onde o Diretor adjunto insistiu para se substituísse o livro utilizado pelo livro Menina Bonita do Laço de Fita ${ }^{24}$ com a finalidade de evitar problemas para a professora. Ana se negou a trocar o livro e afirmou sua intenção de desmistificar o personagem Exu durante suas aulas. O diretor adjunto argumentou tratar-se de currículo de Ensino Religioso - uma disciplina não prevista na grade curricular da Prefeitura de Macaé naquele período - sendo incompatível com uma escola e com um Estado Brasileiro laico ${ }^{25}$.

Quanto à posição da diretora, que se declarou negra e evangélica, esta informou que os alunos fizeram reclamações de haver apologia religiosa nas aulas de Ana, e de esta lhes causar temor pelo ocultismo fazendo ameaças de usar uma tatuagem de pirâmide com um olho afirmando que poderia vigiá-los por meio deste. Relatou ainda que a professora teria obrigado um dos alunos a usar uma faixa escrita com a inscrição Exu, segurar cartazes de desenhos do mesmo e ser fotografado contra a sua vontade.

Houve grande procura da direção da escola com diversas reclamações quanto ao conteúdo abordado em sala de aula. Organizaram-se reuniões de pais e alunos para discutir o problema que, na opinião dos pais, seria a temática religiosa inserida no livro Lendas de Exu. O principal argumento da reclamação dos pais foi sobre a temática religiosa, que na opinião deles, não poderia ser tratada na escola.

Diante das reclamações dos pais e a recusa de Ana em mudar o livro utilizado em sala, a diretora a colocou à disposição ${ }^{26}$ da Secretaria de Educação. Ana procurou a Comissão de Combate à Intolerância Religiosa (CCIR), que publicou uma moção de desagravo em um jornal do Estado do Rio de Janeiro. Outros jornais de grande circulação também publicaram notas e reportagens e o caso prossegue no judiciário.

\section{Joana, é muito grande o preconceito}

\footnotetext{
${ }^{24}$ Trata-se de um livro infantil, de Ana Maria Machado, uma autora de literatura infanto-juvenil consagrada, que narra a história de um coelho branco que, após conhecer uma menina negra e considera-la a pessoa mais linda que já viu em toda sua vida, faz diversas tentativas para se tornar ele próprio tão "pretinho" como a menina. $\mathrm{O}$ livro é uma referência muito utilizada em escolas para tratar do tema diversidade racial, geralmente, utilizado para as primeiras series do ensino fundamental ou pré-escolar.

${ }^{25}$ Ainda que a Constituição da República Federativa do Brasil, em seu art. 210, § 1 , e a Lei 9394/96, em seu art. 33, estabeleçam que sua oferta seja obrigatória no ensino fundamental, porém de matrícula facultativa.

${ }^{26} \mathrm{O}$ funcionário é colocado em suspenso de suas atividades profissionais para ser realocado em outra instituição pública.
} 
Fechando o nosso texto, apresentamos a narrativa vivenciada pela professora Rose, recolhida na pesquisa sobre intolerância religiosa sofrida pelos praticantes de religiões de matrizes africanas, relacionada ao cotidiano do exercício profissional:

\begin{abstract}
Tenho 58 anos, trabalho há trinta anos como professora de primeira à quarta em uma escola de freiras. Todos esses anos tive que esconder minha religião. Eu sabia que, se as irmãs descobrissem minha religião, eu seria mandada embora do trabalho. Nesses anos presenciei inúmeras vezes as formas desrespeitosas com que tratavam minha religião. A dor era maior por não poder reagir, pois reagir naquela situação era certeza de perder o emprego. Quantas vezes para não aparecer na escola com marcas de minha religião tive que inventar uma doença, forjar um atestado médico para justificar minhas faltas. Na minha religião existem preceitos que muitas vezes exigem usar um turbante branco, ou até mesmo toda a roupa branca. Como aparecer assim na escola? É muito difícil fingir essas coisas. A gente aprende com o tempo a conviver escondendo essas coisas que, para nós, são tão preciosas. O preconceito é muito grande. As pessoas não entendem ou não querem entender, então discriminam (ROCHA, ROCHA, 2017, p. 343)
\end{abstract}

\title{
7 Moralidades e cosmologias em conflito
}

Em todas as situações, as professoras demonstram alguma tendência a valorizar suas religiões, ou seja, abordaram temáticas no cotidiano escolar sob a perspectiva de uma crença específica, privilegiando seus credos. Em alguns deles, como nos casos relatados por Quintana e no de Ana, de maneira consciente e proposital. As professoras dos casos registrados enfatizaram em sua prática características culturais, históricas e religiosas afrobrasileiras.

Contudo, ao contrário das professoras de Ensino Religioso que efetivamente têm a prerrogativa de abordar o a religião como fenômeno sociológico, cultural e filosófico, professoras das demais disciplinas não teriam essa permissão, ainda que haja a Lei $\mathrm{n}^{\mathbf{0}} 10.639$, podendo ser alvo de críticas e reclamações dos membros da comunidade escolar de realizarem proselitismo religioso, contudo a transversalidade concede a liberdade de abordagem do tema.

As aulas e ações das professoras tiveram uma grande repercussão, gerando uma controvérsia na escola. A utilização do livro Lendas de Exu inaugurou uma sucessão de conflitos, que envolveu pais, alunos, diretores, professores, Secretaria de Educação, CCIR e a mídia. Isto ocorreu em virtude de sua repercussão em um determinado público, pondo em cheque concepções morais estabelecidas, atingindo certos valores socialmente prestigiosos.

Ao escolher o livro Lendas de Exu, a professora pôs frente a frente moralidades conflitantes, produzindo um choque de cosmologias distintas. Personagens como Exu, ou não 
tem lugar ou ocupam uma posição negativa, associado ao Mal e ao Diabo, no universo cosmológico cristão, sendo sua importância na cultura afro-brasileira simétrica e inversa ${ }^{27}$.

O caso de Conceição que alegou ter sofrido discriminação caracterizada pelo distanciamento de professores de confissão evangélica e presenciado casos de discriminação, como quando os alunos e professores precisam comparecer as festas religiosas e a retiram-se para "fazer o santo". Eles não são amparados por nenhuma lei que os permita fazê-lo sem prejuízo de seu cumprimento da agenda escolar que inclui trabalhos, provas e frequência não inferior a 75\%, apesar das liberdades garantidas na Constituição de 1988. A evocação de crença religiosa como motivo para o descumprimento de obrigação só é aceita mediante o cumprimento de prestação alternativa ${ }^{28}$.

Soma-se a isto o relato de que docentes e discentes candomblecistas preferem se declarar espíritas ou católicos com medo de serem discriminados, citando o exemplo do uso da expressão "filho do diabo" por uma professora ao se referir a um aluno recém iniciado.

\section{Referências}

MACHADO, Ana Maria. Menina bonita do laço de fita. São Paulo: Ática, 1988.

MARTINS, Adilson. Lendas de Exu. Rio de Janeiro: Pallas, 2005.

MIRANDA, Ana Paula Mendes de. Entre o privado e o público: considerações sobre a (in)criminação da intolerância religiosa no Rio de Janeiro. Anuário Antropológico, Vol. 35, n. 2, p. 125-152, dez. 2010. UNB - Departamento de Antropologia, Brasília, 2010.

QUINTANA, Eduardo. Intolerância Religiosa na Escola: O que professoras filhas de santo têm a dizer sobre esta forma de violência. In: Revista Fórum Identidades ITABAIANA: GEPIADDE, ano 07, vol. 14, p. 127-140, jul./dez. 2013.

- No terreiro também se educa: relação candomblé-escola na perspectiva de candomblecistas. Tese (Doutorado em Educação) - Universidade Federal Fluminense, Niterói, 2012.

ROCHA, José Geraldo da; ALBUQUERQUE, Gabriela Girão de. Cultura afro-brasileira na escola e a intolerância religiosa. In: MONTEIRO, Rosana Batista (Org.). Práticas pedagógicas para o ensino de história e cultura afro-brasileira, africana e indígena no ensino médio. Seropédica: Evangraf, 2013, p. 113-131.

\footnotetext{
${ }^{27}$ De acordo com a cosmologia afro-brasileira, Exu é o primogênito da criação. "Guardião dos mercados, templos, casas e cidades. Ensinou aos homens a arte divinatória" (VOGEL, MELLO,PESSOA DE BARROS, 2007,p.195).

${ }^{28}$ Constituição da república Federativa do Brasil de 1988. Art. $5^{\circ}$ Todos são iguais perante a lei, sem distinção de qualquer natureza, garantindo-se aos brasileiros e aos estrangeiros residentes no País a inviolabilidade do direito à vida, à liberdade, à igualdade, à segurança e à propriedade, nos termos seguintes:

$[\ldots]$

II - ninguém será obrigado a fazer ou deixar de fazer alguma coisa senão em virtude de lei;

$[\ldots]$

VIII - ninguém será privado de direitos por motivo de crença religiosa ou de convicção filosófica ou política, salvo se as invocar para eximir-se de obrigação legal a todos imposta e recusar-se a cumprir prestação alternativa, fixada em lei;
} 
ROCHA. Marcos Porto Freitas da. Discriminação e intolerância religiosa: desafios ao ensino religioso. Dissertação (Mestrado em Humanidades Culturas e Artes) - UNIGRANRIO, Duque de Caxias, 2016.

ROCHA, M. P. F. da.; ROCHA, J. G. Análise da experiência de docentes de religiões afrobrasileiras. Anais do XXI Congresso Nacional de Linguística e Filologia: Textos Completo, TOMO I, p. 333 - 345, Rio de Janeiro, 2017.

SIMMEL, Georg. Questões fundamentais de sociologia. Rio de Janeiro: Jorge Zahar, 2006.

VOGEL, Arno; MELLO, Marco Antonio da Silva; BARROS, José F. P. Galinha d'Angola: Iniciação e Identidade na Cultura Afro-Brasileira. 3a ed. Rio de Janeiro: Pallas, 2007.

\title{
Pedagogia apofática do olhar - Uma nova proposta para o ensino religioso
}

Apophatic pedagogy of the look - A new proposal for religious education

Túlio Fernandes Brum de Toledo ${ }^{29}$

Tuliotoledo@hotmail.com

\begin{abstract}
Resumo: Tradições orientais do Vedanta, do Taoísmo e do Budismo, e suas formas mais distintas de hermenêutica acerca da realidade, aparecem como importantes modelos interpretativos de como as realidades surgem manifestadas de diferentes formas. Analisando os ensinamentos das antigas sabedorias, reconhece-se a necessidade de uma pedagogia no Ensino Religioso amparada num movimento Derridiano da desconstrução de paradigmas. Proposta esta, que trata a realidade como um conceito em aberto, possibilitando assim, que o educando passe a atuar como instaurador crítico e reflexivo de sua própria identidade. A pedagogia apofática, apresenta-se fiel ao atual cenário pós- moderno líquido. Reconhece-se isenta de positivismo e assume a fluidez em sua proposta estrutural de aplicabilidade conceitual.
\end{abstract}

Palavras-chave: Desconstrução, realidade, pedagogia, Ensino Religioso.

\begin{abstract}
Eastern traditions of Vedanta, Taoism, and Buddhism, and their most distinct forms of hermeneutics about reality, appear as important interpretative models of how realities emerge manifested in different forms. Analyzing the teachings of the old wisdoms, it is recognized the necessity of a pedagogy in the Religious education supported by a Derridian movement of the deconstruction of paradigms. This proposal, which treats reality as an open concept, thus enabling the student to act as a critical and reflexive institutor of his own identity. The apophatic pedagogy, stands faithful to the current liquid postmodern scenario. It is acknowledged to be free of positivism and assumes fluidity in its structural proposal of conceptual applicability.
\end{abstract}

Keywords: Deconstruction, reality, pedagogy, Religious education

\section{Introdução}

O presente artigo vincula-se a uma questão fundamental, a problemática do

\footnotetext{
${ }^{29}$ Aluno da Graduação em Ciência da Religião na Universidade Federal de Juiz de Fora.
} 
condicionamento da educação tradicional na esfera do Ensino Religioso (ER), onde a verdade objetificadora se faz detentora da realidade última, tornando a pedagogia uma prática limitadora de potenciais, atuando exatamente contra seu objetivo de existência, previsto por lei ${ }^{30}$, que visa o desenvolvimento Pleno - uma simbiose entre racionalidade e intuição/sensibilidade - de todo indivíduo.

Diante do deserto de possibilidades hermenêuticas acerca do entendimento sobre a "realidade", Jacques Derrida com sua desconstrução, opta pelo caminho da abstração, ou da redução fenomenológica. Ao se pensar no novo paradigma religioso pós- moderno, a desconstrução pode vir a ser uma importante aliada na busca pela supressão de preconceitos e na eliminação de atitudes discriminatórias. Diante de um cenário extremamente plural, o reconhecimento da diversidade, assume um papel fundamental no processo de respeito à alteridade. O mundo é um espaço de convivência entre seres de origens distintas, com costumes e dogmas religiosos diferentes, enfim, com visões de mundo diversas.

Toda essa jornada de desconstrução apresenta-se como proposta de questionamento de um processo histórico, lógico, racional e limitado, amparado numa "realidade" dada como única, certa e verdadeira. $\mathrm{O}$ reconhecimento da potencialidade humana de expressar e criar verdades torna a desconstrução de extrema importância na formação de um indivíduo pleno, capaz de formular e estruturar sua própria identidade livre. O pensamento está diante da tarefa de abrir a racionalidade à dimensão própria do absoluto. Diante da desconstrução conceitual só me resta o mergulho na alteridade absoluta. Onde o respeito e o diálogo são características naturais.

Amparado pelo movimento Derridiano da desconstrução, as tradições orientais apresentam-se aqui, como potenciais modelos de esvaziamento conceitual. Tradições como o Vedanta, o Taoísmo e o Budismo, e suas distintas formas de abordagem hermenêutica acerca da realidade de todas as coisas, ratificam a fluidez dos paradigmas rígidos históricos ocidentais. Analisando os ensinamentos das antigas sabedorias, objetivar-se-á demonstrar o caráter não totalitário dos discursos. A aplicabilidade de um modelo desconstrucionista no Ensino Religioso propõe-se a reconhecer a singular diversidade nas formas de entendimento e prática da experiência do sentido. Aplicando a desconstrução, a realidade surge como um conceito em aberto, possibilitando a construção de uma identidade livre, crítica e reflexiva. A desconstrução apresenta-se fiel ao atual cenário pós-moderno líquido.

\footnotetext{
${ }^{30}$ Diz o artigo 205 da Constituição Federal de 1988: "A educação, direito de todos e dever do Estado e da família, será promovida e incentivada com a colaboração da sociedade, visando o pleno desenvolvimento da pessoa, seu preparo para o exercício da cidadania e sua qualificação para o trabalho".
} 
Reconhece-se isenta de positivismo e assume a fluidez em sua proposta estrutural de aplicabilidade conceitual.

\section{Desconstrucionismo}

Incomparável mestre em arte, oh, Theuth ${ }^{331}$, uma coisa é o homem capaz de trazer à luz a fundação de uma arte, outra aquele que é capaz de apreciar o que esta arte comporta de prejuízo ou utilidade para os homens que deverão fazer uso dela. Neste momento, eis que em tua qualidade de pai dos caracteres da escritura, atribuíste-lhes, por complacência para com ele, todo o contrário de seus verdadeiros efeitos. Pois este conhecimento terá, como resultado, naqueles que o terão adquirido, tornar suas almas esquecidas, uma vez que cessarão de exercer sua memória: depositando, com efeito, sua confiança no escrito, é do fora, graças às marcas externas, e não do dentro e graças a si mesmos. Não é, pois, para a memória, mas para a rememoração que tu descobriste um remédio. Quanto à instrução é a aparência (doxa) dela que ofereces a teus alunos, e não a realidade (alétheian): quando, com efeito, com a tua ajuda, eles transbordarem de conhecimentos sem terem recebido ensinamento, parecerão bons para julgar muitas coisas, quando, na maior parte do tempo, estarão privados de todo julgamento; e serão, além disso, insuportáveis, já que terão a aparência de homens instruídos em vez de serem homens instruídos (PLATÃO apud DERRIDA, 2005 p. 49)

$\mathrm{Na}$ leitura de Platão, sem recusar a oferenda de Theuth, o rei, apresentou não apenas o caráter frustrado da escrita - sendo que somente em aparência é que ela é positiva à memória - mas declarou sua iminente ameaça. A escrita manifesta-se na exterioridade do indivíduo, sendo ela exterior à memória e produtora apenas de opiniões e não de verdade. Theuth defende que a escrita servirá como um elixir (pharmakon em grego), pois permitirá que os indivíduos armazenem e, em seguida, acessem seus pensamentos, mas o rei previa que a prática da escrita ocasionaria - oposta a ideia que o deus defendia - iria causar o enfraquecimento da memória, pois essa invenção iria gerar esquecimento nas mentes dos que fariam o seu aprendizado, visto que deixarão de praticar e passarão apenas a acessar. $\mathrm{O}$ armazenamento rígido de conhecimento com base em verdades prontas matriciais cristaliza o potencial fluido de conhecimento existente num indivíduo livre e reflexivo.

Observando o movimento desconstrucionista, a linguagem quando reduzida a forma pura de escrita, minimiza sua capacidade, já relativa, de instauradora da realidade. Dito isto, Derrida sugere um "transbordamento" da escrita que "sobrevém no momento em que a extensão do conceito de linguagem apaga todos os seus limites" (DERRIDA, 2005). Este transbordamento aparece como uma abertura para pluralidade de interpretações e uma não fixação de sentido. Ou seja, Derrida defende que existe uma impossibilidade para os sistemas completamente fechados dos discursos (cristalização), sendo inviável a

${ }^{31}$ Theuth: Deus egípcio criador da escrita 
proliferação de verdades prontas objetivas e restritivas. A escrita sendo uma representação linguística, que através de uma espécie de "transliteração" de essência, encontra-se limitada na sua tentativa fiel de expressar a significação Excelsior da verdade.

\footnotetext{
Gostaria de dispensar vocês do tédio, do desperdício de tempo, e da inutilidade que sempre acompanha os procedimentos pedagógicos clássicos

- ao forjar elos, referindo-se de volta a premissas prévias ou argumentos, justificando a própria trajetória, método, sistema, enfim, transições hábeis para restabelecer continuidade, e assim por diante. Esses são alguns imperativos da pedagogia clássica com os quais, para estar seguro, nunca se poderá romper de uma vez por todas. Porém, se nos submetêssemos a eles rigorosamente, eles acabariam por reduzir tudo ao silêncio, à tautologia e à repetição cansativa. (DERRIDA, 1971)
}

É importante observar que Derrida não se encontra inteiramente dentro nem fora da pedagogia clássica. Ele defende o conceito de recalcular as possibilidades da liberdade acadêmica. Derrida insiste que não deseja "transformar-se num porta-voz da eterna pedagogia", o caráter dinâmico do conhecimento coloca-o sempre em movimento. (DERRIDA, 2002).

A educação sendo uma proposta legítima de aprendizado encontra-se desviada de seu sentido existencial, onde o ensino livre é sobrepujado pela tradição histórica pedagógica - que se apresenta focada na conservação do método ou do sistema - cujo objetivo deixa de ser uma propagação sincera de conhecimento, e torna-se uma auto- justificação de práticas próprias. A pedagogia apofática expansiva no Ensino Religioso deixará de formar agentes encomendados por distintos e complexos sistemas de controle, e passará auxiliar na formação estrutural identitária do indivíduo livre. Logo, a Desconstrução proposta no Ensino Religioso é entendida como uma corrente teórica

dinâmica que pretende balançar as correntes hierárquicas rígidas da pedagogia tradicional, sustentadoras do pensamento ocidental.

O objetivo não é Kantiano de "crítica pura da razão", mas sim, de expansão nas formas de ser e estar no mundo. Derrida defende que operar essa expansão, ou essa fase de expansão, "significa ainda operar no terreno e no interior do sistema desconstruído". Assim, ao buscar desestruturar os discursos com os quais atua, revelando seus pressupostos, suas ambiguidades, contradições, a Desconstrução se apresentará como uma reformulação no interior dos discursos sustentadores do pensamento religioso metafísico ocidental. Desta forma, a metodologia de "eliminação de erro" pretende desestabilizar os conceitos fechados oriundos do pensamento "racional" e, por conseguinte, ampliar seus limites ou limiares. 
sublimante e idealizante da oposição em questão e, de outro, a emergência repentina de um novo 'conceito', um conceito que não se deixa mais - que nunca se deixou - compreender no regime anterior. (DERRIDA, 2002, p. 48)

Interpretando esta "inversão" através do sistema Marxista: a ideia de Tese aparece sendo o sistema atual brasileiro de Ensino religioso laico confessional, a antítese surge como o laicismo francês da extrema razão, e desta mistura pulsante, uma síntese brota como o Ensino religioso expansivo da concepção de realidades, que aliado a desconstrução de paradigmas "ideais" impostos passivamente pela cultura, mostrar-se- á fidedigno ao objetivo mais puro de desenvolvimento humano. Com a atenção voltada às palavras de Derrida, podemos afirmar que a Desconstrução causou um forte impacto no pensamento metafísico ocidental, ao proporcionar questionamentos, deslocamentos, re-alocações de conceitos que antes eram considerados canônicos. O redimensionamento desses conceitos ocasionou um abalo na estrutura hegemônica dos discursos, tendo assim, todo e qualquer discurso, a tentativa de ser detentor da verdade última, o mesmo era colocado como alvo de questionamentos. Desta forma, na análise de Jonathan Culler, observa-se que:

Desconstruir uma oposição é mostrar que ela não é natural e nem inevitável, mas uma construção, produzida por discursos que se apóiam nela, e mostrar que ela é uma construção num trabalho de desconstrução que busca desmantelá-la e reinscrevê-la, isto é, não destruí-la, mas dar-lhe uma estrutura e funcionamento diferentes. (CULLER, 1999, p. 122).

Com isso, Derrida enfraquece a posição dominadora da centralidade, concedendo às margens um lugar de destaque. Margens estas, representadas por todo o cenário subjetivo de não-verdade, onde discursos tradicionais metamorfosear-se-ão de absolutos para relativismos. O ensino religioso desconstrutivo atuará nestas margens, proporcionando assim, uma pedagogia amparada no sentimento de responsabilidade perante o educando.

[...] não era um lugar fixo, mas uma função, uma espécie de não-lugar no qual se faziam indefinidamente substituições de signos. Foi então o momento em que a linguagem invadiu o campo problemático universal; foi então o momento em que, na ausência de centro ou de origem, tudo se torna discurso - com a condição de nos entendermos sobre essa palavra - isto é, sistema no qual o significado central, originário ou transcendental, nunca está absolutamente presente fora de um sistema de diferenças. (DERRIDA, 2002, p. 232).

De acordo com Derrida, a ideia de que o mundo apresenta-se sob a forma de conteúdos logicamente estabelecidos, absorto em verdades próprias, é um simples pressuposto de que a realidade apresentada é, de acordo com os princípios da lógica, coerente e racional, e por isso, verdadeira. No ato de contradizer as leis da lógica, o 
movimento contraditório é considerado como falso e inaceitável. Derrida defende que mesmo condicionadas, é a consciência e a linguagem que possibilitam o "conhecer das coisas", entretanto, apresenta a concepção de que existe conhecimento além da lógica. A intuição do indivíduo senciente é campo aberto de conhecimento, e este processo intuitivo, que está além da razão e da lógica, é, na verdade, excluído do processo pelo qual obtemos conhecimento.

Tais considerações já são suficientes para demonstrar o posicionamento deste pensador desconstrucionista. É por isso que a linguagem, na riqueza de seus diferentes significados, nas ambiguidades que tais diferenças necessariamente trazem e nos jogos de associações que ela proporciona, realiza significações tão múltiplas que jamais um significado fixo ou uma interpretação única para um texto, poderá ser assumido como verdade última. Quando se pensa estar trabalhando com conceitos, está, de fato, lidando com palavras, o que leva à conclusão de que todo conhecimento textual é, portanto, relativo. Para Foucault, essa circunstância conduzia a fundamentos do conhecimento que direcionavam a própria dinâmica cultural.

Se a interpretação não se pode nunca acabar, isto quer simplesmente significar que não há nada a interpretar, porque no fundo tudo é interpretação, cada símbolo é em si mesmo não a coisa que se oferece à interpretação, mas a interpretação de outros símbolos (FOUCAULT, s/d, p.16).

A convicção de Derrida de que tudo aquilo que se quer patentear como verdade é, ao final, resultado de uma articulação linguística que está sempre marcada pela indeterminação e pela ambiguidade. Ao proceder essa crítica à linguagem, que é, por extensão, uma crítica a toda filosofia ocidental, Derrida tem como objetivo incluir, no campo da vivência do sujeito, todos aqueles elementos e sentidos que a lógica excluiu de nossa intuição consciente. Vê-se, assim, que o filósofo trabalha com a perspectiva do resgate de perdas que tiveram lugar na dimensão explícita do discurso lógico textual. A desconstrução visa questionar a estruturação interior dos textos, com a finalidade de "revelar" aquilo que os sintomas dos enunciados obscurecem. Desse modo, é preciso advertir que uma leitura desconstrucionista não busca por uma verdade última, e nem pretende afirmar-se como suposta realidade, pois sua vocação encontra-se no questionamento puro e simples dos discursos cristalizados pela extrema racionalização lógica.

Todo o pensamento ocidental foi desabrochado a partir de uma "arte de criar conceitos". O oriente parece ignorar a conceituação porque se contenta em fazer coexistir o vazio mais abstrato e o ente mais trivial, sem necessidade de mediações. A nascente do 
conhecimento está em diversos e distintos lugares, indeterminada, tanto chinesa, como árabe ou indiana. Mas aí aparece a lógica ocidental, com suas leituras interpretativas do pensamento grego, assume o estranho privilégio de dar à fonte o nome de ser.

Ao contrário do discurso filosófico herdado do logos grego, que sente a necessidade constante de justificar seus fundamentos e proposições, o pensamento chinês, operando a partir de um substrato comum implicitamente aceito, é incapaz de apresentar-se como uma sucessão de sistemas teóricos. (CHENG, p. 124)

\section{A realidade segundo a Tradição Taoísta}

Na tradição Taoísta, o Tao sinaliza "o caminho da realidade", uma verdadeira base da qual todas as coisas jorram, o qual não pode ser apreendido pelo intelecto. De acordo com o anúncio de abertura do Tao-Te-Ching: "O caminho que pode ser expresso não é o Caminho constante" (LAOTSE, 1998, p. 19). O Tao inefável e transcendente está acima de todas as coisas, por trás de todas as coisas, debaixo de todas as coisas. As palavras não estão à altura dele, o Tao é o "útero" dinâmico do qual brota toda a vida e para o qual toda a vida retorna.

O discurso racional consegue exerce rum domínio lógico até certo ponto, para além do qual, só resta mergulhar no esquecimento para reencontrar-se numa outra ordem. Para Chuang-tse: "No Tao nunca houve nem sequer um início de delimitação, como também nunca houve na linguagem um início de permanência. Desde que se diz 'é isso', há um limite" (p. 130). Conquanto seja, em última análise, transcendente, o Tao também é imanente. Assumindo o sentido da imanência, ele é o "caminho do universo", a norma, a força criadora de toda a natureza, o princípio regulador de toda a vida. A matéria não consegue sobrepujar o caráter intuitivo do espírito - ele não se exaure - quanto mais acessado, mais a potencialidade fluida sensitiva aparece, como uma nascente inesgotável, um "espírito da totalidade universal".

O taoísmo não se interessa pelo sentido estrito e restritivo racional, ele assume a sabedoria intuitiva como fonte de conhecimento e reconhece as limitações e os relativismos do mundo do pensamento racionalizador. Numa leitura da tradição chinesa surge o conceito de libertação Taoísta, como especificamente, uma liberdade das regras rígidas da convenção.

O Tao que pode ser dito não é o Tao constante. O nome que pode nomeá-lo não é o nome constante. Sem-nome (começo do Céu-Terra), Com-nome (Mãe das dez mil coisas). Assim, no Sem-desejo constante, consideremos o germe. No Com-desejo 
constante, consideremos o termo. (LAOZI apud CHENG, p. 226)

Palavras que aparentam rigorosa rigidez e que se pretendem verdadeiras parecem ser paradoxais. São os sentidos responsáveis pelo estado de engano contínuo, permitindo-se captar apenas aparências. $\mathrm{Na}$ origem da irrisória certeza de ter controle sobre a realidade, encontram-se as distinções praticadas via categorização da linguagem. São essas diferenças que obscurecem e limitam as funções sensoriais condicionantes dos desejos. A extrema lógica racional manifesta-se no "barulho", no fluxo crescente de descobertas objetificadoras, enquanto isso, o Tao é quietude.

\title{
3. A realidade segundo a Tradição do Vedanta
}

Como exemplo desta capacidade existencial interpretativa de realidade diversa, destaca-se a tradição do Vedanta, cuja abordagem não-dogmática possui enfoque experimental da verdade rumo à possibilidade de extinção do sofrimento. Shankara ${ }^{432}$ dizia que ir atrás da verdade que causou o mundo era transcender o próprio mundo; buscar achar o motivo da ilusão - Maya - seria ultrapassar a ilusão, e quando efetuado isso, Maya desaparece. Ele coloca a capacidade de descobrimento em nossas mãos. Para a filosofia indiana a mente e a matéria se encontram na mesma categoria, portanto, ambas são objetos do conhecimento. Diferente do pensamento racional ocidental que defende uma distinção entre as duas.

\begin{abstract}
Uma clara visão da Realidade só pode ser obtida através de nossos próprios olhos, quando eles se abrirem por meio do discernimento espiritual - mas nunca através dos olhos de outro vidente. Por nossos próprios olhos aprendemos a ver a aparência da lua: como poderíamos aprender isso pelos olhos de outrem? (SHANKARA, 1992. p. 18)
\end{abstract}

O desígnio upanișádico define-se enquanto princípio de unicidade inefável, que transcende a linguagem, e que congrega, enquanto precedência ontológica, o humano e o divino, o sujeito e objeto, o eu e o mundo. A realização fundamental da não diferença ontológica (advaita) entre o conceito existencializado da subjetividade $\left(\bar{a} t m a n^{33}\right)$ e o conceito existencializado de objetividade (brahman) constitui o cerne de todos os

${ }^{32}$ Shankara (686- 718 d.C.) Filósofo indiano que representa uma fonte proeminente da sabedoria oriental.

${ }^{33}$ A palavra ātman, no mundo da dualidade denota, fundamentalmente, a alma individual enquanto algo distinto do corpo que a hospeda. Ela é usada aqui para revelar aquilo que, na realidade, é inexprimível por palavras (avācya). 
empreendimentos místicos da tradição upanișádica.

Os Upanișads são chamados de pramāna ('meio de conhecimento') não porque revelam a natureza de ātman, mas porque eliminam as concepções errôneas naturais sobre sua natureza. A ideia de um processo verdadeiro de remoção de concepções errôneas está em perfeito acordo com a natureza upanișádica de àtman ('não-dual', ou seja, 'realidade única'). Desta forma, a ideia de unicidade radical (advaita) torna impossível uma revelação positiva por meio de palavras. Consequentemente, a realização da natureza legítima da Realidade (mokșa) decorre, tal qual um ato de rememoração originária, apenas e tão somente através da remoção de obstruções.

O método upanișádico de reflexão racional - diferente da racionalidade objetificadora ocidental de base empírica, não possui seus alicerces existenciais em qualquer forma de cognição verbal de caráter representacional. Tudo o que oferece é eliminar os erros que impedem a consciência imediata dessa condição única de coletividade jamais separada. É através de um processo dinâmico e gradual de eliminação da pluralidade de suas manifestações, em outras palavras, o objetivo principal de tais sentenças upanișádicas não é a descrição empírica do processo de criação do mundo, mas tão somente apontar para a insubstancialidade do mundo e sua natureza singular não-dual. Com isso, o método objetiva-se apontar para o nível fundacional, que antecede à própria linguagem e ao próprio indivíduo buscador, enquanto condição individual de possibilidade de sua própria experiência de ser e estar no mundo: o reconhecimento fundamental da não-diferença ontológica entre ātman e brahman, o eu e o mundo.

\section{A realidade segundo a Tradição do Budismo Mahaiana}

Já na tradição fundada pelo mestre Gautama, a totalidade cósmica aparece como uma teia interligada de relações físicas e mentais, cujas partes só podem ser definidas através de suas vinculações com o "todo". O Budista não crê num mundo externo independente, ou existindo separadamente, em cujas forças dinâmicas possa se inserir. O mundo externo e seu mundo interior são, para ele, apenas dois lados do mesmo tecido, no qual "os fios de todas as forças e de todos os eventos, de todas as formas de consciência e de seus objetos, se acham entrelaçados numa rede inseparável de relações intermináveis e que se condicionam mutuamente". (ANDRADE. p. 128)

As diferenças entre criaturas e objetos são meras distinções de superfície, variadas disposições de átomos. Os elementos podem transformar-se em outros elementos. A 
identidade é apenas provisória. Para Yoshinori: "Se tudo tem uma origem interdependente, todas as coisas são vazias de uma natureza própria, ou ser próprio; o vazio é a verdadeira natureza do real" (p. 73), que não pode ser captado por nossas palavras ou conceitos, mas apenas numa meditação intuitiva que se afasta do pensamento dual. Não existe nada que possa ser estabelecido por uma verdade última e que a verdade última está além de toda espécie de atividade verbal.

\begin{abstract}
A ignorância condiciona as determinações; as determinações condicionam a consciência; a consciência condiciona o complexo psicofísico; o complexo psicofísico condiciona a sensibilidade; a sensibilidade condiciona o contato; o contato condiciona a sensação; a sensação condiciona o apego; o apego condiciona o desejo; o desejo condiciona o vir-a-ser; o vir-a-ser condiciona o nascimento; o nascimento condiciona a velhice e a morte. (BUDA Apud. ANDRADE, p. 135)
\end{abstract}

Passamos a acreditar implicitamente na existência de objetos inerentes, já que confundimos o conteúdo da consciência (percepção "a posteriori") com a pura possibilidade cognitiva a priori da consciência. Nenhum caminho é único e nenhuma tradição é portadora da verdade última. Através da desconstrução de "falsas" estruturas de pensamento, o indivíduo deve ser capaz de exercer sua criticidade e ter seu potencial humano elevado, tanto racional, quanto intuitivo.

\title{
5. Ensino religioso - Uma nova proposta pedagógica
}

Assumindo o ensino religioso como um conhecimento humano, o mesmo deve estar disponível à sociabilização. Os conteúdos do ensino religioso apofático não servem de proselitismo, e afastam a ideia de exclusividade no ensino. A propagação confessional de "determinados" conhecimentos, ressurge como um fator impeditivo na constituição de uma identidade crítica, reflexiva e plural, onde a identidade do ser - enquanto/ou na busca, por um cidadão pleno - encontra-se limitada a um condicionamento objetificador racional. $\mathrm{O}$ universo religioso e a história do homem são elementos indissociáveis, o conteúdo didático na sala de aula precisa abarcar toda essa totalidade existencial.

Para viver democraticamente em uma sociedade plural é preciso respeitar as diferentes culturas e grupos que a compõem, posicionando-se contra qualquer discriminação baseada em diferenças culturais, de classe social, de crenças, sexo, etnia ou outras características individuais e sociais. As tradições religiosas devem ser apresentadas com igual destaque, por professores habilitados nesta área de conhecimento. Nenhuma religião deve ser reconhecida, assumida ou ignorada por um Estado Laico Democrático, 
professadas em seu território ou não. A ausência de uma crença ou convicção religiosa no país não dispensa que a escola discuta sobre a mesma ou a inclúia na formação dos alunos.

Por isto é que a investigação se fará tão mais pedagógica quanto mais crítica e tão mais crítica quanto, deixando de perder-se nos esquemas estreitos das visões parciais da realidade, das visões "focalistas" da realidade, se fixe na compreensão da totalidade. (FREIRE, 2017. p. 139)

O ensino religioso não pode usar a força ética das religiões para instruir com estratégias de controle social, como geralmente acontece. O que está em jogo é a busca de um indivíduo com capacidade crítica, capaz de formular sua própria identidade, não precisando assim, "aceitar" verdades prontas matriciais. Explorar a sensibilidade é adentrar no universo do autoconhecimento. Nenhum caminho é único e nenhuma tradição é portadora da verdade última. O indivíduo deve ser capaz de exercer sua criticidade e ter seu potencial humano elevado, tanto racional, quanto intuitivo.

O método adequado não ensina a repetir palavras, não se restringe a desenvolver a capacidade de pensá-las segundo as exigências lógicas do discurso abstrato; simplesmente coloca o alfabetizando em condições de poder re-existenciar criticamente as palavras de seu mundo, para, na oportunidade devida, saber e poder dizer a sua palavra. (FREIRE, 2017.p. 17)

A conscientização refaz criticamente o processo dialético de historicização, em outras palavras, despersonalifica o processo repetitivo consciente histórico. O medo parece que resistiu a derrocada do período medievo e continua sendo de alguma forma - mesmo assumindo outras faces - o grande obstáculo na jornada pelo desenvolvimento pleno. O indivíduo teme a liberdade refugiando-se na segurança vital, como diria Hegel, "preferindoa a liberdade arriscada". A historicidade dominadora não podendo matar a intencionalidade da consciência, a domestica, negando ao indivíduo sua vocação ontológica de humanizarse. No vazio do Eu projetado pela exterioridade encontra-se uma interioridade repleta de potencialidade.

As grandes tradições religiosas continuam operando na sociedade secularizada de maneira matricial e com força política, ao mesmo tempo em que se reproduz em subsistemas que, mesmo sob a égide da autonomia e da ruptura, parecem, na verdade, traduzir e adaptar aqueles antigos padrões às demandas culturais atuais. (PASSOS, 2007)

As práticas pedagógicas de submissão da realidade precisam ser abolidas. Os homens através de suas ações sobre o mundo, como portadores e dominadores da práxis, formulam um "reino" de cultura e história, onde o criador e criatura se interpelam com extrema arrogância, tornando-se assim "impossível" separá-los. O Ensino Religioso 
apofático surge com uma valiosa proposta pedagógica de liberdade, colocando o indivíduo não como um mero repetidor passivo, mas possuidor e instaurador de sua própria verdade. $\mathrm{O}$ aperfeiçoamento intuitivo busca suprimir o preconceito e eliminar atitudes discriminatórias, cujas finalidades envolvem lidar com valores de reconhecimento e respeito à alteridade, o que deve ser tido como missão para a sociedade como um todo. $\mathrm{O}$ ensino tem um papel fundamental a desempenhar nesse processo. A escola é o espaço de convivência entre crianças de origens distintas, com costumes e dogmas religiosos diferentes, enfim, com visões de mundo diversas.

Se eu pudesse, daria um globo terrestre a cada criança... Se possível, até um globo luminoso, na esperança de alargar o máximo a visão infantil e de ir despertando interesse e amor por todos os povos, todas as raças, todas as línguas, todas as religiões! (CÂMARA, 1985, s/p.)

A escola laica pública é propiciadora de uma educação democrática que busca a consolidação e o aprimoramento do indivíduo pleno, junto com direitos e deveres fundamentais da pessoa humana. As tradições e as formas hermenêuticas acerca da realidade, realizadas em outros contextos sociais e culturais, não podem ser abordadas como um erro da verdade, tratadas como sistemas fictícios e fantásticos, limitando o indivíduo em seu mergulho profundo na formação de sua identidade.

\section{Conclusão}

A concepção de universo precisa ser apreendida dinamicamente à medida que se desloca, vibra e dança, ou seja, a natureza não se encontra em equilíbrio estático, mas sim, em um complexo e dinâmico fluxo existencial. No novo paradigma proposto para a prática pedagógica, o Ensino Religioso apresenta-se como ferramenta deconstrutiva de formas diversas de realidade. Assim como o homem se reinventa, ele também reinventa as formas de realidade. Uma pedagogia apofática do olhar busca expandir a concepção do indivíduo acerca dos mais variados discursos "detentores" da verdade.

O resgate da capacidade crítica e o desenvolvimento intuitivo são exercícios viáveis na esfera humana. A devida compreensão da realidade diversa e incognoscível é um passo para o respeito coletivo. A abertura a diversidade apresenta-se como uma forma sublime de aprendizado, mudar e amadurecer é um processo de iniciativa individual. A pedagogia apofática do olhar surge como uma proposta fundamentada na história humana e respeita a 
proposta constitucional de desenvolvimento humano.

Afastando-se de sua prática vivencial, problematizando-a, como uma espécie de desintegração crítica, aprofundando o conhecimento sobre o movimento da consciência, o homem se redescobre, se revisita como indivíduo instaurador desse mundo, de sua própria experiência. Presenciando sua história não só objetivamente, mas também de forma intuitiva, reconhecendo a natureza ingênua da consciência, o indivíduo reconhece as barreiras da percepção e assume um estado virginal, portador de uma nudez existencial pés descalços - pronto para reconhecer-se como personagem que se ignorava e sendo chamado assim, a assumir seu papel.

\section{Referências}

ANDRADE, Clodomir. A Não Dualidade do Um (brahmãdvaita) e a Não Dualidade do Zero (sunyatãdvaya)na ìndia Antiga. Tese (Doutorado em Ciência da Religião) Faculdade de Ciências da Religião, Universidade Federal de Juiz de Fora. Juiz de Fora, 2013.

BHAKTIVEDANTA, A.C. Swami. Além do nascimento e da morte. $8^{\circ}$ ed. São Paulo: Fundação Bhaktivedanta, 1997.

CÂMARA, Hélder. Mil razões para viver. Civilização Brasileira, 1985. CHENG,

Anne. História do Pensamento Chinês. Petrópolis, RJ: Vozes, 2008. CHUNG,

Tsai C. Zen em quadrinhos. 3 ed. Rio de Janeiro: Ediouro, 1997.

CULLER, Jonathan. Sobre a Desconstrução: teoria e crítica do pós-estruturalismo. Trad. Patrícia Burrowes. Rio de Janeiro: Record; Rosa dos Tempos, 1997.

DERRIDA. A escritura e a diferença. São Paulo: Perspectiva, 1971.

. A farmácia de Platão. Trad. Rogério da Costa. São Paulo: Iluminuras. 2005. Gramatologia. São Paulo: Perspectiva, 1973. . O animal que logo sou. São Paulo: Unesp, 2002.

ELIADE, Mircea e Ioan P. Couliano. Dicionário das religiões. Tradução de Ivone Castilho Benedetti. $2^{\circ}$ Ed; São Paulo: Martins Fontes, 1999.

FOUCAULT, Michel. A arqueologia do saber. Petrópolis, RJ: Vozes, 1972. . As palavras e as coisas. São Paulo: Martins, 1966.

FREIRE, Paulo. Pedagogia do oprimido. Rio de Janeiro/ São Paulo: Paz e Terra, 2017.

LAO TSE. Tao te ching: o livro do caminho e da virtude. Rio de Janeiro: Mauad, 1998.

PASSOS, João Décio. Ensino religioso, construção de uma proposta. São Paulo: Paulinas. (Coleção Temas do Ensino Religioso - Pressupostos), 2007.

PESSOA, Fernando. Poesia de Alberto Caeiro. Assírio \& Alvim, 2009. SHANKARA. A Jóia Suprema do Discernimento. Editora: Pensamento, 1997. YOSHINORI, Takeushi. A Espiritualidade Budista. São Paulo: Perspectiva, 2006. 
ZIMMER, Heinrich R. Filosofias da Índia. Compilado por Joseph Campbell; tradução Nilton Almeida Silva, Cláudia Giovani Bozza e participação de Adriana Facchini de Césare; versão final Lia Diskin. São Paulo: Palas Athena, 1986. 